UNIVERSIDADE DE SÃO PAULO

FACULDADE DE ODONTOLOGIA DE RIBEIRÃO PRETO

AMANDA PERACINI

Avaliação in vitro da ação do hipoclorito de sódio e de pastilhas efervescentes quanto à alteração de cor em resinas acrílicas termopolimerizáveis e de microondas

Ribeirão Preto

2008 


\section{Avaliação in vitro da ação do hipoclorito de sódio e de pastilhas efervescentes quanto à alteração de cor em resinas acrílicas termopolimerizáveis e de microondas}

Dissertação apresentada à Faculdade de Odontologia de Ribeirão Preto da Universidade de São Paulo para obtenção do título de Mestre em Reabilitação Oral.

Área de Concentração: Reabilitação Oral Orientadora: Profa. Dra. Helena de Freitas Oliveira Paranhos

Ribeirão Preto 
AUTORIZO A REPRODUÇÃO E DIVULGAÇÃO TOTAL OU PARCIAL DESTE TRABALHO, POR QUALQUER MEIO CONVENCIONAL OU ELETRÔNICO, PARA FINS DE ESTUDO E PESQUISA, DESDE QUE CITADA A FONTE.

\section{FICHA CATALOGRÁFICA}

Ficha catalográfica elaborada pela Biblioteca Central do Campus USP - Ribeirão Preto

Peracini, Amanda

Avaliação in vitro da ação do hipoclorito de sódio e de pastilhas efervescentes quanto à alteração de cor em resinas acrílicas termopolimerizáveis e de microondas. Ribeirão Preto, 2008.

124 p. : il. ; $30 \mathrm{~cm}$

Dissertação de Mestrado, apresentada à Faculdade de Odontologia de Ribeirão Preto/USP. Área de concentração: Reabilitação Oral.

Orientador: Paranhos, Helena de Freitas Oliveira.

1. Prótese Total. 2. Higienizadores de Dentadura. 3. Resinas Acrílicas. 4. Cor. 


\section{AMANDA PERACINI}

Avaliação in vitro da ação do hipoclorito de sódio e de pastilhas efervescentes quanto à alteração de cor em resinas acrílicas termopolimerizáveis e de microondas.

Dissertação apresentada à Faculdade de Odontologia de Ribeirão Preto da Universidade de São Paulo para obtenção do título de Mestre em Reabilitação Oral. Área de Concentração: Reabilitação Oral.

Aprovado em:

Banca Examinadora:

Prof. Dr.

Instituição:

Assinatura:

Prof. Dr.

Instituição:

Assinatura:

Prof. Dr.

Instituição:

Assinatura: 
Aos meus pais, Carlos e Ivete, pelos esforços e incentivos para que buscasse meus ideais, pela formação pessoal e profissional, estando sempre ao meu lado ao longo do período de elaboração deste trabalho. Pela dedicação, apoio, confiança, paciência, sabedoria, ensinamentos, preocupações e educação.

Aos meus irmãos, Alex e Junior, por estarem comigo nesta caminhada, pela convivência, crescimento mútuo, ensinamentos e por fazerem parte da minha vida. 
Agradecimento Especial 
A Profa. Dra. Helena de Freitas Oliveira Paranhos, por todos os ensinamentos, atenção, respeito, incentivo e orientação desde a graduação. Obrigada também pela confiança em mim depositada e pela oportunidade de poder desenvolver este trabalho. Seus conhecimentos e competência contribuíram muito para a orientação deste estudo. 
Agradecimentos 
A Profa. Dra. Claudia Helena Lovato da Silva, por todas as orientações quanto aos procedimentos metodológicos, pela convivência e por toda sua experiência e valiosos conselhos que em muito contribuíram para a realização deste projeto.

Ao Prof. Dr. Raphael Freitas de Souza, pela assessoria na parte estatística deste trabalho, pelos conhecimentos repassados e contribuição no desenvolvimento desta pesquisa.

A Profa. Dra. Iara Augusta Orsi, pelas sugestões fornecidas e por ceder equipamentos fundamentais para a realização deste trabalho.

A Profa. Dra. Alma Blásida Concepción Elizaur Benitez Catirse e Profa. Dra. Valéria Oliveira Pagnano de Souza, pela colaboração e sugestões no Exame de Qualificação, e contribuição no meu crescimento profissional.

Ao Edson Volta por sua ajuda na realização das leituras de cor.

Aos funcionários do Departamento Marcelo, Ricardo, Eduardo e Fernando pelo apoio e sugestões durante a confecção dos corpos-de-prova.

A Regiane de Cássia Tirado Damasceno e Ana Paula Xavier, secretárias do Departamento de Materiais Dentários e Prótese, pela atenção dispensada, informações e orientações a mim prestadas.

À Fundação de Amparo à Pesquisa do Estado de São Paulo pela concessão da bolsa de mestrado e pelo apoio financeiro deste projeto. 
Aos professores, funcionários e colegas do Departamento de Materiais Dentários e Prótese da Faculdade de Odontologia de Ribeirão Preto, Universidade de São Paulo.

Aos amigos da Graduação, da Pós-Graduação pela convivência, amizade e experiências compartilhadas durante esses anos.

A todos que de forma direta ou indireta contribuíram para a realização deste trabalho. 


\section{RESUMO}

PERACINI, A. Avaliação in vitro da ação do hipoclorito de sódio e de pastilhas efervescentes quanto à alteração de cor em resinas acrílicas termopolimerizáveis e de microondas. 2008. 124f. Dissertação (Mestrado) - Faculdade de Odontologia de Ribeirão Preto, Universidade de São Paulo, Ribeirão Preto, 2008.

O objetivo deste estudo foi avaliar a alteração de cor de resinas acrílicas termopolimerizáveis (convencional e de microondas) após imersões em soluções químicas higienizadoras de próteses totais em diferentes períodos de tempo. Foram obtidos padrões em cera $(15 \mathrm{~mm}$ de diâmetro e $4 \mathrm{~mm}$ de espessura), a partir de uma matriz de teflon, que foram incluídos em muflas convencionais e para microondas. Após a eliminação da cera, as resinas foram manipuladas, prensadas e polimerizadas segundo as instruções dos fabricantes. Foram confeccionados 200 corpos-de-prova, 100 de cada marca comercial das resinas Lucitone 550 (L) e Onda Cryl (OC), os quais foram imersos nas soluções: A)Água destilada-3 min.; B)Bony Plus -3 min.; C)Água destilada-5 min.; D)Corega Tabs-5 min.; E)Água destilada-20 min.; F)Hipoclorito de sódio a 0,5\%-20 min.; G)Hipoclorito de sódio a 1\%-20 min.; H)Água destilada-8 horas; I)Hipoclorito de sódio a 0,5\%-8 horas; J)Hipoclorito de sódio a 1\%-8 horas. A alteração de cor foi avaliada empregando-se um espectrocolorímetro (Color Guide 45/0 BYK-Gardner) antes e após a simulação de 180 dias de imersão. Os resultados foram comparados por meio da análise de variância (ANOVA) para dois fatores, seguida pelo teste de Student-Newman Keuls, com nível de significância de 0,05. Para correlacionar as diferenças de cor para o ambiente clínico, os dados foram calculados de acordo com as unidades da National Bureau of Standards (NBS). Os resultados mostraram que a resina Lucitone $550(\Delta \mathrm{E}=0,47 \pm 0,18)$ apresentou-se mais estável que a Onda-Cryl $(\Delta \mathrm{E}=$ $0,53 \pm 0,31)$. Para ambas as resinas, as pastilhas, os hipocloritos por 20 minutos $(0,5 \%$ e $1 \%)$ e por 08 horas $(0,5 \%)$ não provocaram alterações maiores que seus respectivos controles (L-A: $0,27 \pm 0,10$; L-B: $0,44 \pm 0,21$; L-C: $0,48 \pm 0,21$; L-D: $0,46 \pm 0,13$; L-E: $0,29 \pm 0,07$; L-F:

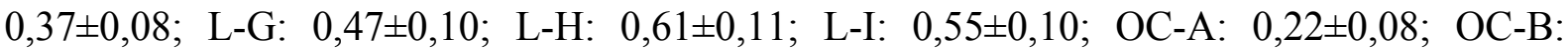

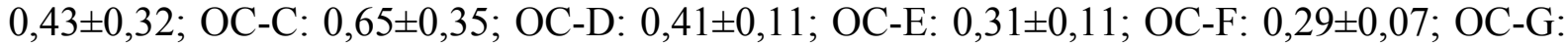
$0,37 \pm 0,11$; OC-H: $0,78 \pm 0,10$; OC-I: $0,79 \pm 0,08$ ). As soluções de hipoclorito a $1 \%$ (L-J: 0,74 $\pm 0,09$; OC-J: $1,06 \pm 0,13$ ) causaram maiores alterações que seus respectivos controles. As soluções empregadas por 08 horas (água e Hipocloritos a 0,5\% e 1\%) provocaram alterações classificadas como "leves", segundo o sistema NBS. Os achados deste estudo revelaram que as pastilhas efervescentes, quando usadas de acordo com as instruções dos fabricantes, e o hipoclorito de sódio $(0,5 \%$ e $1 \%)$ por 20 minutos apresentaram menores valores de alteração de cor nas resinas acrílicas após um período de uso simulado de 180 dias. Médias mais elevadas foram obtidas quando um regime de 8 horas foi simulado.

Palavras-chave: Prótese Total, Higienizadores de Dentadura, Resinas Acrílicas, Cor. 
Abstract 


\begin{abstract}
PERACINI, A. In vitro evaluation of sodium hypochlorite and effervescent tablets action regarding color alteration of heat and microwave-polymerized acrylic resins. 2008. 124f. Dissertação (Mestrado) - Faculdade de Odontologia de Ribeirão Preto, Universidade de São Paulo, Ribeirão Preto, 2008.

The aim of this study was to evaluate color alteration of heat-polymerized acrylic resins (conventional and microwave-polymerized), after immersion in chemicals solutions of denture cleansers for different periods of time. Wax patterns were obtained $(15 \mathrm{~mm}$ in diameter and $4 \mathrm{~mm}$ thickness) from a teflon matrix and were invested in metallic or microwavable flasks. The wax had been eliminated and the resins were mixed, packed and polymerized according to the manufacturers' instructions. Two hundred specimens were made, 100 specimens of each commercial resin Lucitone 550 (L) e Onda Cryl (OC), which were immersed in the solutions: A)Distilled water-3 min.; B)Bony Plus-3 min.; C)Distilled water-5 min.; D)Corega Tabs-5 min.; E) Distilled water -20 min.; F) 0,5\% Sodium Hypochlorite-20 min.; G) 1\% Sodium Hypochlorite-20 min.; H)Distilled water-8 hours; I) $0,5 \%$ Sodium Hypochlorite- 8 hours; J) $1 \%$ Sodium Hypochlorite -8 hours. Color alteration was assessed by a spectrocolorimeter (Color Guide 45/0 (BYK-Gardner) before and after 180 days simulation. The results were analyzed statistically by a two-way analysis of variance (ANOVA), and Student Newman-Keuls test, with significance level of 0.05. To relate the color differences to a clinical environment, the data were quantified by National Bureau of Standards (NBS) units. The results showed that the resin Lucitone $550(\Delta \mathrm{E}=0,47 \pm 0,18)$ was more stable than the resin Onda-Cryl $(\Delta \mathrm{E}=0,53 \pm 0,31)$. For both resins, the tablets, the hypochlorite by 20 minutes $(0,5 \%$ e $1 \%)$ and by 8 hours $(0,5 \%)$ did not produce higher alterations than the respective controls (L-A: $0,27 \pm 0,10$; L-B: $0,44 \pm 0,21$; L-C: $0,48 \pm 0,21$; L-D: $0,46 \pm 0,13$; L-E: $0,29 \pm 0,07$; L-F: $0,37 \pm 0,08$; L-G: $0,47 \pm 0,10$; L-H: $0,61 \pm 0,11$; L-I: $0,55 \pm 0,10$; OC-A: 0,22 $\pm 0,08$; OC-B: $0,43 \pm 0,32$; OC-C: $0,65 \pm 0,35$; OC-D: $0,41 \pm 0,11$; OC-E: $0,31 \pm 0,11$; OC-F: 0,29 $\pm 0,07$; OC-G: $0,37 \pm 0,11$; OC-H: $0,78 \pm 0,10$; OC-I: $0,79 \pm 0,08)$. The $1 \%$ hypochlorite solutions (L-J: 0,74 $\pm 0,09$; OC-J: 1,06 $\pm 0,13$ ) produced higher alterations than the respective controls. The solutions employed by 8 hours (water and $0,5 \%$ and $1 \%$ hipochlorite) produced alterations classified as "slight", according to the NBS system. The findings of this study showed that the effervescent tablets, used according to the manufacturer's instructions, and the sodium hypochlorite $(0,5 \%$ and $1 \%)$ used by 20 minutes presented lower values of color alterations in acrylic resins after a period of 180 days simulation. Higher mean averages were obtained when a period of 8 hours was simulated.
\end{abstract}

Keywords: Denture Complete, Denture Cleansers, Acrylic Resins, Color. 


\section{SUMÁRIO}

1 INTRODUÇÃO ........................................................................................................................... 15

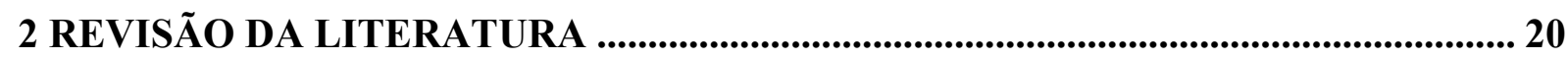

2.1 MATERIAIS E MÉTODOS DE HIGIENE DE PRÓTESES TOTAIS ............................ 21

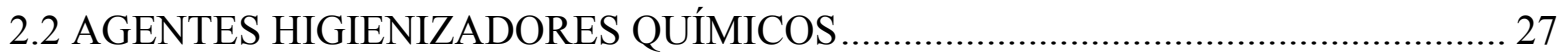

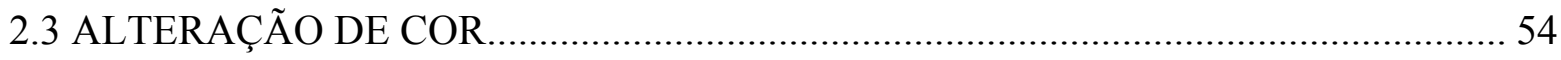

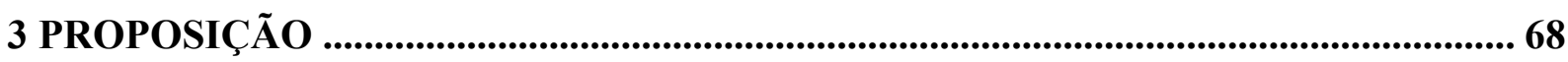

4 MATERIAL E MÉTODO ....................................................................................................... 70

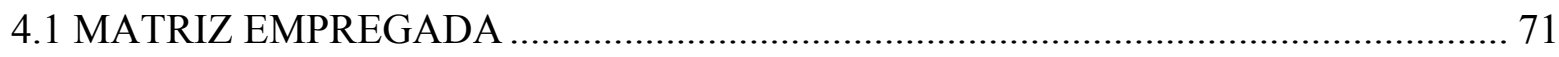

4.2 ENCERAMENTO, INCLUSÃO E OBTENÇÃO DOS CORPOS-DE-PROVA.............. 72

4.3 ACABAMENTO E POLIMENTO DOS CORPOS-DE-PROVA ……………………..... 75

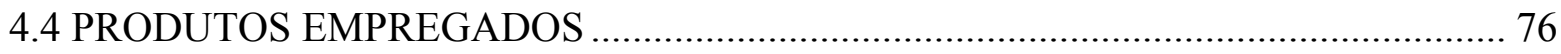

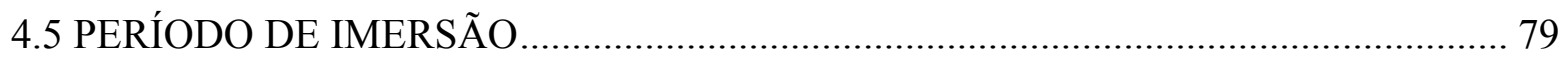

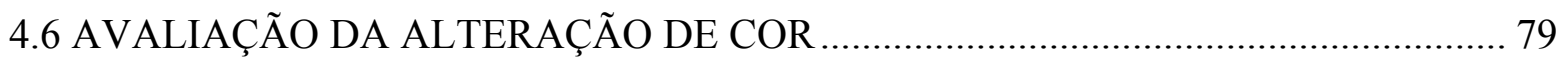

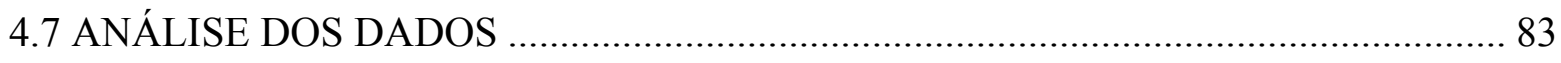

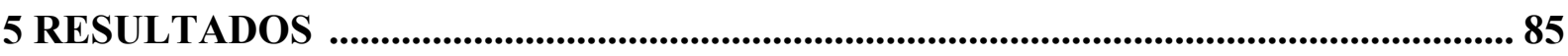

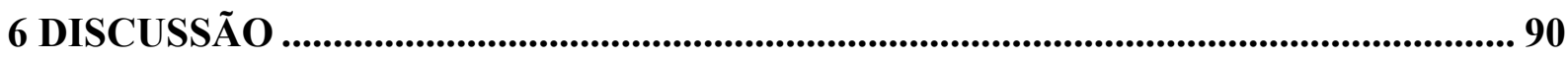

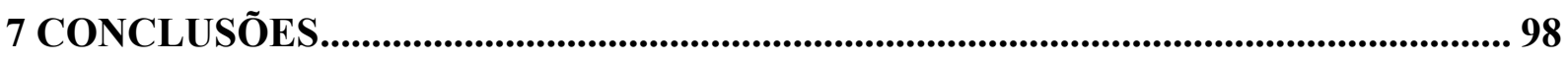

REFERÊNCIAS BIBLIOGRÁFICAS …...................................................................... 100

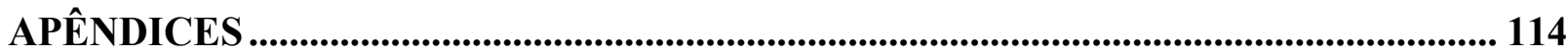


A saúde oral de usuários de próteses totais é precária (HOAD-REDDICK; GRANT; GRIFFITHS $^{41}$, 1990; KULAK-OZKAN; KAZAZOGLU; ARIKAN ${ }^{52}$, 2002; SCHOU; WIGHT; CUMMING ${ }^{94}$, 1987), sendo comum o aparecimento de lesões associadas a higienização deficiente das próteses (KULAK-OZKAN; KAZAZOGLU; ARIKAN ${ }^{52}, 2002$; MARCHINI et al. ${ }^{62}$, 2004; SCHOU; WIGHT; CUMMING ${ }^{94}$, 1987). A má higiene está associada à falta de orientação (DIKBAS; KOKSAL; CALIKKOCAOGLU ${ }^{34}, 2006$; HOADREDDICK; GRANT; GRIFFITHS ${ }^{41}$, 1990), às características intrínsecas do aparelho, à diminuição da destreza manual dos pacientes (DILLS et al. ${ }^{35}, 1988$; KULAK-OZKAN; KAZAZOGLU; ARIKAN $\left.{ }^{52}, 2002\right)$, bem como à ineficácia dos produtos para limpeza das próteses (BUDTZ-JØRGENSEN $\left.{ }^{19}, 1979\right)$. A correta higienização oral é indispensável para a manutenção da saúde bucal e geral do paciente, especialmente em idosos, influenciando sua qualidade de vida (BUDTZ-JØRGENSEN ${ }^{19}$, 1979; DE VISSCHERE et al. ${ }^{31}$, 2006; SHAY ${ }^{97}$, 2000), sendo importante também para uma maior longevidade das próteses (DIKBAS; KOKSAL; CALIKKOCAOGLU ${ }^{34}$, 2006). Assim, cabe ao cirurgião-dentista orientar seus pacientes corretamente quanto à higienização e os produtos a serem utilizados.

O biofilme da prótese total é definido como uma camada microbiana densa formada por microrganismos e seus produtos metabólicos, sendo constituído por mais de $10^{11}$ microrganismos por grama em peso seco (NIKAWA; HAMADA; YAMAMOTO ${ }^{75}, 1998$ ). Uma higienização deficiente pode contribuir para halitose, bem como resultar em mudanças inflamatórias na mucosa oral $\left(\mathrm{NEILL}^{72}, 1968\right.$; $\left.\mathrm{SHAY}^{97}, 2000\right)$, merecendo destaque a Candídiase Atrófica Crônica (Estomatite de Dentadura), sendo o biofilme o principal fator etiológico desta patologia (BUDTZ-JØRGENSEN; BERTRAM ${ }^{21}$, 1970; NIKAWA; HAMADA; YAMAMOTO ${ }^{75}$, 1998; SESMA et al. ${ }^{95}$, 1999). Com a presença do biofilme, os microorganismos presentes, especialmente Candida albicans, iniciam a colonização e tornam o biofilme patogênico (NIKAWA; HAMADA; YAMAMOTO ${ }^{75}$, 1998, SESMA et al. ${ }^{95}$, 
1999). O biofilme, quando aspirado, pode levar também a infecções oportunistas, principalmente imunocomprometidos (NIKAWA; HAMADA; YAMAMOTO ${ }^{75}$, 1998; SUMI et al. $\left.{ }^{101}, 2002\right)$. A presença de bactérias em próteses removíveis foi relacionada com doenças sistêmicas, principalmente infecções respiratórias (SUMI et al. ${ }^{101}, 2002$ ).

O produto ideal para a higienização das próteses deve ser de fácil manuseio; efetivo na remoção dos depósitos orgânicos, inorgânicos e manchas; bactericida e fungicida; não tóxico ao paciente; não deletério aos materiais constituintes do aparelho e de baixo custo (ABELSON² $^{2}$ 1985; BUDTZ-JØRGENSEN ${ }^{19}$, 1979; JAGGER; HARRISON ${ }^{44}$, 1995). Vários agentes são indicados para a remoção do biofilme, sendo classificados em mecânicos e químicos (BUDTZ-JØRGENSEN ${ }^{19}$, 1979; JAGGER; HARRISON ${ }^{44}, 1995 ;$ KENG; LIM $^{47}$, 1996; POLYZOIS ${ }^{84}$, 1983). Os métodos mecânicos são compreendidos por escovação e tratamento ultra-sônico. Métodos químicos são classificados, de acordo com sua composição e mecanismo de ação, em hipocloritos alcalinos, peróxidos alcalinos, peróxidos neutros com enzimas, enzimas, ácidos, drogas brutas, detergentes, e enxaguatórios bucais (NIKAWA et al. $\left.^{76}, 1999\right)$.

A higienização pelo método químico consiste na imersão do aparelho em soluções com ação solvente, detergente, bactericida e fungicida, sendo que podem ser utilizadas de forma isolada ou associadas a métodos mecânicos de limpeza, como por exemplo, a escovação (CHAN et al. ${ }^{24}$, 1991; DILLS et al. ${ }^{35}$, 1988; NIKAWA et al. ${ }^{76}, 1999$; PARANHOS et al. ${ }^{80}$, 2007; $\left.\mathrm{SHAY}^{97}, 2000\right)$. É um método efetivo frente às bactérias presentes no biofilme das próteses (CHAN et al. $\left.^{24}, 1991\right)$, apresentando vantagens de efetividade de limpeza, ausência de abrasão e simplicidade de uso $\left(\mathrm{ABERE}^{3}, 1979\right)$. Como principais desvantagens, podem ser citados a possibilidade de clareamento da resina acrílica, a corrosão de componentes metálicos e o alto custo dos produtos no mercado (ABELSON ${ }^{2}, 1985 ; \mathrm{ABERE}^{3}, 1979$; COUNCIL ON DENTAL MATERIALS, INSTRUMENTS AND EQUIPMENT ${ }^{26}$, 1983; 
MCNEME; VON GONTEN; WOOLSEY ${ }^{67}$, 1991; ROBINSON; MCCABE; STORER ${ }^{90}$, 1985; ÜNLÜ; ALTAY; SAHMALI ${ }^{105}$, 1996). Existem duas classes principais de higienizadores de imersão: os hipocloritos alcalinos e os peróxidos alcalinos (ABELSON ${ }^{1}$, 1981; $\left.\operatorname{SHAY}^{97}, 2000\right)$.

O objetivo da imersão da prótese em produtos químicos é a obtenção de limpeza e descontaminação. O processo não deve envolver nenhuma alteração física, mecânica, ou química da prótese, sendo importante à análise da eficácia do produto higienizador versus sua atuação sobre os materiais constituintes do aparelho (NEPPELENBROEK et al. ${ }^{73}, 2005$; PAVARINA et al. ${ }^{81}$, 2003a). As resinas acrílicas têm sido usadas para confecção de próteses totais por mais de 60 anos e são compostas por poli (metil-metacrilado) (ANUSAVICE ${ }^{8}$, 2005; CRAIG; POWERS ${ }^{28}$, 2004). Os diferentes métodos de polimerização podem alterar as suas propriedades físicas e mecânicas (LAI et al. $\left.{ }^{55}, 2004\right)$. A termopolimerização em banho de água aquecida é o método mais utilizado para processamento das mesmas, embora pesquisas contínuas tenham originado outros métodos, buscando maior facilidade na confecção de próteses. A polimerização de resinas acrílicas pela energia de microondas é efetiva e proporciona aquecimento uniforme e rápido, economizando tempo no processamento (KIMURA et al. $^{49}$, 1983; KIMURA; TERAOKA; SAITO ${ }^{50}$, 1984). Tais achados são confirmados até os dias atuais (LAI et al. $\left.{ }^{55}, 2004\right)$.

Um problema freqüentemente relatado pelos usuários de higienizadores químicos e que preocupa pacientes, dentistas e fabricantes, é o clareamento da resina acrílica da prótese, sendo que fatores como temperatura da água (ARAB; NEWTON; LLOYD ${ }^{10,9}, 1988,1989$; CRAWFORD et al. ${ }^{30}, 1986$; ROBINSON; MCCABE; STORER ${ }^{89}$, 1987) e tempo de imersão (MA; JOHNSON; GORDON ${ }^{58}$, 1997; MCNEME; VON GONTEN; WOOLSEY ${ }^{67}$, 1991; POLYZOIS et al. ${ }^{85}$, 1997) são considerados críticos. Algumas vezes, torna-se necessária a substituição das próteses devido ao uso indevido de métodos de higiene (JAGGER; 
HARRISON $^{44}$, 1995). A estabilidade de cor tem sido testada em materiais reembasadores (BATES; SMITH $^{16}$, 1965; GOLL; SMITH; PLEIN ${ }^{39}$, 1983; JIN et al. ${ }^{45}, 2003$; TAN et al. ${ }^{102}$, 2000) e resinas acrílicas após o emprego de soluções desinfetantes (MA; JOHNSON; GORDON $^{58}$, 1997; MCNEME; VON GONTEM; WOOLSEY ${ }^{67}$, 1991; POLYZOIS et al. ${ }^{85}$, 1997) e higienizadores específicos de próteses totais (ARAB; NEWTON, LLOYD ${ }^{10,9}, 1988$, 1989; CRAWFORD et al. $^{30}$, 1986; PAZZINI; MUTTI; PAZZINI ${ }^{83}, 1972$; PURNAVEJA et al. $^{87}$, 1982; ROBINSON; MCCABE; STORER ${ }^{90,89}, 1985,1987$; SATO et al. ${ }^{93}, 2005$; ÜNLÜ; ALTAY; SAHMALI ${ }^{105}$, 1996), sendo salientada a importância do seguimento das instruções do fabricante.

Os peróxidos alcalinos são higienizadores químicos mais comumente utilizados $\left(\mathrm{ABELSON}^{2}, 1985 ; \mathrm{SHAY}^{97}, 2000\right)$. Os hipocloritos diluídos têm sido indicados como higienizadores de próteses totais (NIKAWA et al. ${ }^{76}, 1999$; $\mathrm{SHAY}^{97}, 2000$ ). As alterações de cor, com o emprego desses produtos, têm sido realizadas em períodos curtos de imersão (ARAB; NEWTON, LLOYD ${ }^{10}$ 9 , 1988, 1989; MA; JOHNSON; GORDON ${ }^{58}, 1997$; MCNEME; VON GONTEM; WOOLSEY ${ }^{67}, 1991$; POLYZOIS et al. ${ }^{85}, 1997$; SATO et al. ${ }^{93}$, 2005; ÜNLÜ; ALTAY; SAHMALI ${ }^{105}$, 1996). Sendo assim, torna-se importante a análise de tal propriedade simulando períodos prolongado de uso, uma vez que a troca da prótese total é indicada após 05 a 07 anos (ZARB; BOLENDER; CARLSSON ${ }^{114}, 2000$ ). Além disso, a retirada da prótese durante o período do sono e imersão em soluções higienizadoras é freqüentemente recomendada. 
2 Revisão da Literatura 


\subsection{Materiais e métodos de higiene de próteses totais}

A limpeza da prótese inicialmente foi caracterizada por princípios estéticos, porém os benefícios da saúde bucal tornaram-se evidentes $\left(\mathrm{ABELSON}^{2}\right.$, 1985). A higienização da prótese por parte do paciente nem sempre é a correta, ou por negligência do paciente, ou por falta de orientação do cirurgião dentista (DIKBAS; KOKSAL; CALIKKOCAOGLU ${ }^{34}, 2006$; JAGGER; HARRISON ${ }^{44}$, 1995), pois cabe ao cirurgião dentista incentivar e instruir o paciente quanto aos cuidados com suas próteses e saúde bucal (MARTINS et al. ${ }^{63}, 2004$ ).

O biofilme presente na superfície da prótese total é um dos fatores etiológicos da estomatite, podendo ser prejudicial tanto à mucosa oral, como a saúde geral do paciente, podendo causar infecções locais ou sistêmicas que, em determinadas ocasiões, podem apresentar complicações (NIKAWA; HAMADA; YAMAMOTO ${ }^{75}$, 1998).

Portanto, é necessário um controle efetivo do biofilme, sendo necessária uma higienização adequada da prótese, pois a aderência de microrganismos e resíduos é favorecida por superfícies irregulares e rugosas (AUGSBURGER; ELAHI ${ }^{11}, 1982$; LACERDA $^{54}, 1998$; $\left.\mathrm{SHAY}^{97}, 2000\right)$. Um regime rotineiro de higiene deveria ser indicado para remover e prevenir o acúmulo de biofilme, restos alimentares, cálculos e descolorações exógenas (BUDTZJØRGENSEN $\left.{ }^{19}, 1979\right)$.

Os usuários de próteses totais podem fazer uso regular de métodos de higienização não convencionais que deterioram as próteses (JAGGER; HARRISON $\left.{ }^{44}, 1995\right)$. Pacientes podem apenas enxaguar as próteses em água, usar produtos caseiros para limpeza ou utilizar água em temperaturas muito elevadas. A ingestão acidental de alguns higienizadores ou próteses que não foram adequadamente enxaguadas após a imersão, podem causar queimaduras ou 
toxicidade (COUNCIL ON DENTAL MATERIALS, INSTRUMENTS AND EQUIPMENT $^{26}$, 1983). Ainda, em relação a efeitos colaterais, trabalhos mostram que, higienizadores em pó, quando em contato com a mucosa ou ingeridos acidentalmente, devido à sua constituição química, podem causar sérias complicações e queimaduras no trato digestivo, edema local, inflamação e descamação da mucosa (ABRAMSON et al. ${ }^{5}, 1974$; ABRAMSON et al. ${ }^{6}, 1975$; ABRAMSON $\left.{ }^{4}, 1978\right)$. Portanto, os usuários de próteses totais deveriam ter conhecimento adequado sobre o uso destes agentes higienizadores; instruções que deveriam vir escritas nas embalagens como prescrições do fabricante (COUNCIL ON DENTAL MATERIALS, INSTRUMENTS AND EQUIPMENT ${ }^{26}$, 1983). O conhecimento, por parte dos cirurgiões-dentistas, a respeito destes produtos, isto é, sua constituição, eficácia, agentes adversos e inocuidade, ajudam na informação adequada a ser fornecida ao paciente.

Com a necessidade de manutenção de limpeza da prótese, começou-se a pesquisar produtos que seriam úteis para auxiliar os pacientes na limpeza de suas próteses. Porém, os testes de eficácia desses produtos são complexos e os resultados relatados são variados e freqüentemente dependem das condições experimentais (COUNCIL ON DENTAL MATERIALS, INSTRUMENTS AND EQUIPMENT $\left.{ }^{26}, 1983\right)$.

Abelson $^{2}$ (1985) evidencia que o produto ideal deveria ser de fácil uso, remover efetivamente os depósitos (orgânicos e inorgânicos), ser bactericida e fungicida, não tóxico ao paciente e não provocar nenhum dano aos materiais usados na prótese. Jagger e Harrison ${ }^{44}$ (1995) acrescentam a necessidade do produto ter um sabor agradável e ser relativamente barato para possibilitar o seu uso regular. Segundo Abere $^{3}$ (1979), para se desenvolver um programa de higiene, deve-se levar em consideração, entre outros aspectos, a coordenação física, idade e hábitos alimentares do paciente, bem como o material que a prótese é confeccionada. 
O uso de agentes químicos em procedimentos protéticos incluem a desinfecção dos materiais de base de prótese, tratamento de infecções por Candida albicans, e uso como soluções para limpeza das próteses (KWOK; RALPH ${ }^{53}$, 1984). Existe uma variedade de soluções, pastas e pós disponíveis no mercado para limpeza das próteses (JAGGER; HARRISON $^{44}$, 1995), que contêm uma variedade de ingredientes. Aqueles do tipo pasta contêm abrasivos moderados. Produtos químicos para imersão de próteses geralmente contêm agentes antimicrobianos como o hipoclorito ou agentes oxidantes (DILLS et al. ${ }^{35}, 1988$ ), ou mesmo enzimas (NAKAMOTO; TAMAMOTO; HAMADA $\left.{ }^{71}, 1991\right)$.

Langwell $^{56}$ (1955), em um dos primeiros trabalhos sobre higienizadores de prótese, classifica-os em hipocloritos alcalinos, peróxidos alcalinos e ácidos clorídricos diluídos. Os pós-abrasivos não são considerados, pois, segundo o autor, podem prejudicar a adaptação do aparelho.

Smith $^{100}$ (1966) dividem os agentes de limpeza em pós, soluções de hipocloritos alcalinos, soluções de peróxidos alcalinos, ácidos minerais diluídos e pastas. Segundo o autor, embora a escovação rotineira com sabão mantenha uma superfície polida da dentadura, existem estudos mostrando a necessidade de um auxílio suplementar. Evidências clínicas e comerciais mostram que higienizadores oxidantes são muito utilizados, mas que nem sempre são efetivos, sendo necessária a formulação de um higienizador que solubilize rapidamente o depósito sem afetar o material da prótese.

MacCallum et al. ${ }^{59}$ (1968) dividem os higienizadores em dois grupos: soluções higienizadoras (hipocloritos alcalinos, peróxidos alcalinos e ácidos minerais diluídos) e higienizadores abrasivos (pós e pastas). Realizaram uma avaliação dos hábitos de higiene de próteses por meio de questionários e exame da prótese. De um total de 1000 pacientes verificou-se que uma ampla variedade de higienizadores era usada, totalizando 34 materiais diferentes, sendo muito utilizado o higienizador peróxido alcalino. Destes 1000 pacientes, 
somente 175 estavam insatisfeitos com seu método de limpeza da prótese, sendo que 698 possuíam próteses manchadas.

Abere $^{3}$ (1979) divide os higienizadores em agentes químicos para imersão (hipocloritos alcalinos, peróxidos alcalinos, ácidos diluídos e enzimas), ultra-som, escovação e pastas ou abrasivos para dentaduras. Segundo ele, a prótese deve ser higienizada diariamente para a remoção de biofilme e resíduos alimentares, com a utilização de uma escova específica para prótese e sabão suave. Em áreas onde a escova não alcança, áreas que necessitam de esterilização e remoção de manchas, deve-se usar uma solução diluída de alvejante, a qual pode ser friccionada na superfície da prótese. Soluções de imersões devem ser utilizadas, como no caso de pacientes debilitados ou idosos que não podem fazer uso da escova, desde que o paciente tome certas precauções.

Budtz-Jørgensen ${ }^{19}$ (1979), divide os agentes higienizadores em aqueles pertencentes ao método mecânico (escovação, pastas e pós, agitação ultra-sônica) e ao químico (peróxidos alcalinos, hipocloritos alcalinos, agentes desinfetantes e enzimas). De acordo com o autor, próteses mal higienizadas são conseqüência da limpeza mecânica inadequada e a ineficácia da maioria dos produtos comerciais para higienização química das próteses. Também destaca a importância do biofilme na saúde da mucosa oral e na saúde geral do paciente, sendo que é obrigação do paciente manter a higienização por meio de cuidados diários e obrigação do dentista instruir e motivar o paciente. $\mathrm{O}$ autor salienta que pesquisas devem ser direcionadas para o desenvolvimento de agentes higienizadores, os quais mantenham as próteses isentas de biofilme com um período de imersão diário de 15 a 30 minutos e não afetem a cor e a superfície polida da resina acrílica. O autor recomenda o uso de escova macia e pasta com baixo teor abrasivo.

Uma especificação sobre os higienizadores de prótese (COUNCIL ON DENTAL MATERIALS, INSTRUMENTS AND EQUIPMENT ${ }^{26}$, 1983) afirma que os produtos 
comercialmente disponíveis são classificados em pastas abrasivas suaves, agentes oxidantes (hipocloritos, peróxidos e persulfatos), ácidos minerais e enzimas. Também afirma que os testes de eficácia dos higienizadores apresentam resultados variados, pois dependem das condições do teste. Também alertam para os riscos dos higienizadores, devendo o paciente observar as precauções quando da ingestão acidental dos produtos ou enxágüe inadequado das próteses após as imersões. As instruções e indicações do uso de tais produtos deveriam vir escritas na prescrição dos fabricantes.

Ferran et al. ${ }^{36}$ (1984) dividem a higienização da prótese total em higiene do aparelho e higiene da mucosa (língua, rebordos alveolares residuais e palato). Os produtos devem ser anti-sépticos e não corrosivos à prótese. Os autores preconizam a escovação do aparelho e da mucosa 3 vezes ao dia e a imersão rotineira do aparelho por no mínimo 10 minutos em antisépticos.

Abelson $^{2}$ (1985) classifica os agentes higienizadores em soluções químicas para imersão (hipocloritos alcalinos e peróxidos alcalinos), agentes abrasivos (pós e pastas), ácidos, ultrasom, antibacterianos e enzimas. O autor realizou uma revisão de literatura sobre biofilme e higienizadores de prótese, modo de ação e eficácia, e concluiu que o produto ideal para higienização das próteses não existe e que deve ser recomendado o uso de mais de um produto para suprir as necessidades da maioria dos pacientes. Concluiu que a escovação com pasta apropriada é o método mais eficaz e deve ser o método de escolha para pacientes com destreza manual. No caso de próteses acrílicas, a imersão em soluções de hipoclorito é também efetiva para aqueles pacientes que necessitam do emprego de uma solução de imersão, podendo ser utilizado também o peróxido alcalino.

Paranhos, Malachias e Pardini ${ }^{79}$ (1991) classificam os agentes higienizadores em métodos mecânicos (escovação e ultra-som) e químicos (hipocloritos alcalinos, peróxidos alcalinos, ácidos, enzimas e desinfetantes). Segundo os autores, obtém-se uma limpeza efetiva 
com uma limpeza combinada, isto é, associação dos métodos mecânico e químico; o paciente deve ser bem instruído quanto ao uso dos agentes higienizadores, sendo de sua responsabilidade manter a higiene por meio de cuidados diários.

Jagger e Harrison ${ }^{44}$ (1995) fazem a mesma classificação anterior. Apresentam os resultados de uma pesquisa avaliando o conhecimento dos pacientes quanto aos procedimentos de higienização e materiais e métodos utilizados para limpeza das próteses. Foi aplicado um questionário a 100 pacientes, que consistiu de cinco questões sobre higiene de prótese e produtos de limpeza. Os resultados mostraram que um grande número de pacientes não sabe como higienizar suas próteses e que utiliza diversas combinações de métodos de higienização, sendo os peróxidos alcalinos amplamente utilizados, seguidos pelos hipocloritos alcalinos. Os autores recomendam escovação com escova macia com sabão e posteriormente, a imersão em solução de hipoclorito alcalino por 20 minutos, bem como a imersão das próteses em água durante a noite.

Nikawa et al. ${ }^{76}$ (1999) realizaram uma revisão de literatura sobre métodos de higiene empregados e sua eficácia. Afirmaram que os diversos higienizadores de prótese não mostram a mesma efetividade, não mostrando a mesma eficácia in vivo que in vitro. Concluíram enfatizando a necessidade de padronização da metodologia, realização de ensaios in vitro e in vivo e avaliação qualitativa e quantitativa do biofilme presente na prótese.

Shay $^{97}$ (2000), classifica os métodos de higiene em mecânicos (escovação e uso de aparelho ultra-sônico), químicos (solução doméstica, exposição ao oxigênio por meio de secagem e radiação por microondas) e combinado. A solução doméstica mais comumente utilizada é o alvejante (hipoclorito de sódio) diluído 1:10 em água de torneira. O autor concluiu que a escovação é inadequada para controle do biofilme, e que a imersão em solução de hipoclorito de sódio diluída ou em produto efervescente comercial consiste em método efetivo de limpeza. 


\subsection{Agentes químicos higienizadores}

Os principais higienizadores químicos para imersão de próteses constituem-se em soluções de hipocloritos e peróxidos alcalinos (ABELSON$\left.{ }^{1}, 1981\right)$.

O hipoclorito foi a primeira solução química usada rotineiramente para imersão de próteses totais $\left(\mathrm{ABERE}^{3}, 1979\right.$; $\left.\mathrm{LANGWELL}^{56}, 1955\right)$, sendo efetivo na dissolução da matriz orgânica na qual se forma o cálculo $\left(\mathrm{ABERE}^{3}, 1979\right.$; BUDTZ-JØRGENSEN ${ }^{19}, 1979$; NEILL $^{72}, 1968 ;$ SMITH $\left.^{100}, 1966\right)$. É um agente bactericida e fungicida $\left(\right.$ ABELSON $^{2}, 1985$; BUDTZ-JØRGENSEN ${ }^{19}$, 1979; WEBB et al. ${ }^{111}$, 1995). O uso deste agente de imersão foi por algum tempo questionado, por causar corrosão dos componentes metálicos das próteses; porém novas formulações surgiram, com a incorporação de substâncias anticorrosivas, tais como hexametafosfato de sódio, buscando superar esta desvantagem (LANGWELL ${ }^{56}, 1955$; NEILL $^{72}$, 1968). Uma desvantagem importante consiste em seu odor desagradável (MACCALLUM et al. ${ }^{59}$, 1968; SMITH $^{100}, 1966$ ); além disso, devem ser cuidadosamente manuseados para evitar contato com a pele e vestuários (COUNCIL ON DENTAL THERAPEUTICS AND COUNCIL ON PROSTHETIC SERVICES AND DENTAL LABORATORY RELATIONS ${ }^{27}$, 1985; MOLINARI; RUNNELS ${ }^{69}$, 1991). Porém, a recomendação clínica do uso de soluções alvejantes domésticas diluídas para higienização e esterilização de próteses acrílicas é comum (JAGGER; HARRISON ${ }^{44}$, 1995; SMITH $^{100}$, 1966). Tem sido sugerido que a imersão noturna consiste em um método efetivo na higienização de próteses acrílicas (BASSON; QUICK; THOMAS ${ }^{15}$, 1992; BUDTZJØRGENSEN $^{19}$, 1979; HUTCHINS; PARKER ${ }^{73}, 1973$; NEILL $\left.{ }^{72}, 1968\right)$, embora usuários de 
próteses resistam em remover seus aparelhos protéticos durante a noite (KEYF; GÜNGÖR ${ }^{48}$, 2003).

A grande desvantagem é que essa substância pode provocar clareamento da resina acrílica, dependendo de sua concentração e do tempo de imersão (LACERDA ${ }^{54}, 1998$ ). Existem controvérsias dos efeitos do hipoclorito sobre reembasadores (TAN et al. ${ }^{102}, 2000$ ).

Tais agentes não são recomendáveis em próteses com componentes metálicos. (BACKENSTOSE, WELLS ${ }^{13}$, 1977; COUNCIL ON DENTAL THERAPEUTICS AND COUNCIL ON PROSTHETIC SERVICES AND DENTAL LABORATORY RELATIONS $^{27}$, 1985; MOLINARI; RUNNELS ${ }^{91}$, 1991; RUTALA; WEBER ${ }^{92}$, 1997), principalmente com ligas de cobalto-cromo, as quais são particularmente suscetíveis à corrosão pelo hipoclorito $\left(\mathrm{ABERE}^{3}, 1979\right.$; MACCALLUM et al. ${ }^{59}, 1968$ SMITH $^{100}, 1966$; WAGNER $\left.^{106}, 1973\right)$. Taylor e Jordan ${ }^{104}$ (1967) relataram um caso de corrosão de metal em uma prótese total inferior contendo cobalto-cromo imersa em soluções contendo cloro.

Os peróxidos alcalinos, nos quais, rotineiramente o agente ativo é o perborato de sódio, quando dissolvidos em água, tornam-se soluções alcalinas de peróxido de hidrogênio (BUDTZ-JØRGENSEN ${ }^{19}$, 1979; COUNCIL ON DENTAL MATERIALS, INSTRUMENTS AND EQUIPMENT ${ }^{26}, 1983$; LANGWELL $^{56}, 1955$ NEILL $^{72}, 1968 ;$ SMITH $\left.^{100}, 1966\right)$, que, em contato com a matriz orgânica do biofilme, ou seja, restos alimentares e mucinas, decompõem-se originando bolhas de gás oxigênio (LANGWELL ${ }^{56}, 1955$; SMITH $^{100}, 1966$ ). A ação higienizadora destes materiais depende, em parte, do aumento destas bolhas de oxigênio que, em contato com a matéria orgânica da prótese, exerce uma limpeza mecânica (BUDTZ-JØRGENSEN $^{19}$, 1979; JAGGER; HARRISON ${ }^{44}, 1995$ NEILL $^{72}, 1968 ;$ SMITH $^{100}$, 1966). Os peróxidos alcalinos possuem uma ação mais pronunciada durante o período inicial e sua potência diminui com o esfriamento da solução (NEILL $\left.{ }^{72}, 1968\right)$. 
São mais efetivos na remoção de depósitos leves (KENG; LIM $^{47}, 1996$; LANGWELL ${ }^{56}$, 1955; NEILL ${ }^{72}$, 1968) e possuem leve ação antibacteriana (ABELSON $\left.{ }^{2}, 1985\right)$. Não há contra-indicações do uso destes materiais em resinas acrílicas (JAGGER; HARRISON ${ }^{44}$, 1995; NEILL $\left.{ }^{72}, 1968\right)$, mas estes materiais podem afetar materiais reembasadores de prótese (BATES; SMITH ${ }^{16}, 1965$; LACERDA $\left.{ }^{54}, 1998\right)$.

Smith $^{99}$ (1961) realizou um estudo de higienizadores de prótese, avaliando a eficácia na higienização, a possível corrosão e outros efeitos deletérios aos materiais constituintes da prótese. Foram utilizados 20 higienizadores, classificados em três grupos: limpeza por ação abrasiva, por meios químicos e associada (química e abrasiva). No primeiro grupo, foram utilizados 3 pós abrasivos suaves. No grupo químico foram avaliados 8 peróxidos alcalinos, 1 hipoclorito alcalino e 6 soluções de ácidos diluídos. No terceiro grupo foi realizada escovação associada a alguns dos higienizadores químicos. Amostras de resina acrílica foram tratadas diariamente por um ano com estes higienizadores, de acordo com as instruções dos fabricantes. O exame visual das amostras revelou pequenos efeitos deletérios, sendo que a imersão não foi efetiva na remoção de depósitos calcificados. Sendo assim, recomenda-se a escovação associada a higienizadores químicos.

$\mathrm{Neill}^{72}$ (1968) realizou uma pesquisa de higienização de próteses, avaliando a eficácia dos produtos utilizados e seus efeitos deletérios na prótese. Uma das etapas da pesquisa consistiu na aplicação de um questionário aos pacientes, revelando os hábitos de limpeza das próteses. No teste clínico, onze higienizadores de próteses totais para imersão e abrasivos (Dento, Dentifresh, Sanident, Librox, Eucryl, Steradent, Wernets, Dentural, Oxydent, Kolynos e Lustredent) foram distribuídos a 76 indivíduos durante um período experimental de cinco semanas. Na fase laboratorial, próteses foram seccionadas, sendo metade usada como controle e metade submetida a procedimentos de higienização (imersão e escovação). Foram realizadas imersões de 8 horas diárias por um período de seis dias. Também foi avaliada a 
capacidade de limpeza de 21 higienizadores em próteses manchadas. Tanto no teste clínico, como no laboratorial, foram utilizadas fotografias das próteses ou das amostras obtidas antes e após o uso dos produtos higienizadores. Concluiu que a imersão noturna em soluções de peróxido alcalino e hipoclorito constitui-se em método seguro e efetivo de higienização, e que a escovação pode causar danos à resina acrílica; sendo assim devem ser usados produtos de baixa abrasividade.

Nicholson, Stark e $\operatorname{Scott}^{74}$ (1968) avaliaram várias soluções de limpeza de prótese isoladas, ou combinadas com um aparelho de ultra-som. Foram coletadas de consultórios dentais, 96 próteses maxilares e mandibulares de resina acrílica, com vários graus de depósitos e manchas. As próteses foram distribuídas em três grupos, de acordo com a quantidade de manchas e resíduos: A) altos níveis; B) níveis intermediários; e C) níveis baixos. As próteses foram imersas por 10 minutos nas seguintes soluções: 1) hipoclorito de sódio $5 \%$ e água; 2) higienizador comercial e água, de acordo com as instruções dos fabricantes; 3) higienizador de prótese experimental e água; 4) aparelho sônico e higienizador experimental; 5) aparelho sônico e água; 6) aparelho sônico e hipoclorito de sódio. Foi realizada uma comparação visual das 96 próteses e 24 foram selecionadas como representativas para uma avaliação detalhada. O aparelho sônico com hipoclorito de sódio foi mais efetivo que a solução de hipoclorito de sódio. A higienização efetiva da maioria das próteses foi obtida com leve escovação após a imersão na solução higienizadora. A solução de hipoclorito de sódio foi efetiva, e em muitos casos superior aos outros agentes de higienização testados. Concluíram que a higienização das próteses está relacionada à atividade química das soluções e apresenta uma pequena relação à atividade vibratória do dispositivo de limpeza. $\mathrm{O}$ uso de hipoclorito de sódio seguido por leve escovação foi o método de limpeza mais efetivo.

Hutchins e Parker $^{42}$ (1973), investigaram 11 higienizadores (pós ou tabletes), dissolvidos em água, quanto à capacidade de remoção de biofilme. Participaram deste estudo 
7 pacientes usuários de próteses totais e próteses parciais removíveis, confeccionadas de materiais convencionais, incluindo resina acrílica, liga cobalto-cromo e porcelana. O estudo foi dividido em várias fases. O biofilme das próteses foi evidenciado com solução de azul de metileno a 4\% (preparado em partes iguais de álcool e água), e escovado até sua remoção. Em uma primeira fase, as próteses foram usadas pelos pacientes por 24 horas sem nenhum procedimento de higienização. Após evidenciação do biofilme e fotografia, as próteses foram colocadas em imersão em diferentes períodos (15 minutos e 6 horas). Em uma segunda fase, os pacientes imergiam suas próteses durante a noite por 7 dias. Na terceira fase, dois pacientes imergiram suas próteses por 7 dias em água de torneira durante a noite, sem nenhum procedimento de higienização. Após uma semana as próteses foram imersas por 15 minutos e uma hora em uma única solução de hipoclorito sódio-fosfato (Mersene - Davies Rose Hoyt Pharmaceutical Division). Em cada fase, as próteses foram enxaguadas em água, fotografadas, coradas e fotografadas novamente para avaliação do biofilme. Na quarta fase, próteses parciais removíveis confeccionadas com liga de cobalto-cromo foram imersas por dois meses em solução de hipoclorito alcalino (Mersene), sendo esta solução trocada diariamente. Os resultados mostraram que na primeira fase, o hipoclorito de sódio (Mersene) foi à única solução a remover o biofilme após 15 minutos ou 6 horas de imersão, sendo também efetivo nas imersões durante a noite por uma semana. Este estudo demonstrou que a imersão regular durante a noite em hipoclorito alcalino (Mersene) foi efetivo contra o acúmulo de biofilme, e que não causou efeitos adversos nos materiais das próteses. Os autores também advertem sobre a dificuldade de remoção do biofilme maduro em comparação ao biofilme acumulado por 24 horas, por isso as próteses devem ser escovadas até sua completa limpeza e posteriormente imersas no período noturno.

Backenstose e Wells ${ }^{13}$ (1977) estudaram os efeitos de higienizadores de próteses em componentes metálicos de próteses parciais removíveis e totais. Amostras de três metais: 
Nickel-chromium (Ticonium 100, Regional Dental Activity), Aluminum (Aluminum Company of América) e Stainless steel (Elgiloy) foram imersas em: Polident (Block Drug Company), Efferdent (Warner-Lambert Company), Mersene (Davies), Clorox (The Clorox Company), Calgon-Clorox (Consumer Products Company), Vinegar (H. J. Heinz Company), água destilada, água de torneira e controle (sem imersão). Os metais foram imersos nas soluções por um total de 240 horas, sendo que as soluções foram trocadas a cada 8 horas. As amostras foram analisadas quanto à descoloração (oxidação) e corrosão. Os resultados mostraram que não ocorreu descoloração ou corrosão dos metais imersos em Polident, Efferdent, água destilada ou água de torneira. Severa oxidação foi observada nos metais imersos na solução de Clorox. Concluíram que alvejantes comerciais e soluções de hipoclorito não tamponadas não devem ser usadas em próteses com componentes metálicos.

Budtz-Jorgensen e Knudsen ${ }^{22}$ (1978) avaliaram a eficácia dos métodos de escovação e imersão. Setenta e quatro pacientes com Estomatite Protética receberam novas próteses e foram distribuídos nos seguintes grupos: 1) Escovação com escova específica para prótese (Tandex ${ }^{\circledR)}$ com gel contendo gluconato de clorexidina 1\%; 2) Escovação com escova específica para prótese (Tandex $\left.{ }^{\circledR}\right)$ e gel placebo (ICI-Macclesfield); 3) Método rotineiro de limpeza de prótese associado à imersão em solução de peróxido alcalino (Steradent®); 4) Método rotineiro de limpeza de prótese associado à imersão em solução placebo. Os pacientes foram instruídos a escovar as próteses duas vezes por dia e, no caso das imersões, foram instruídos a dissolver um tablete em $150 \mathrm{ml}$ de água morna $\left(37^{\circ} \mathrm{C}\right)$, e a imergir as próteses novas por 15 minutos diariamente, durante 1 mês. Os níveis de biofilme, as condições clínicas da mucosa palatina, e a concentração de leveduras (mucosa e prótese) foram avaliadas nas próteses antigas e novas. Os resultados mostraram que houve formação de biofilme em todas as próteses, porém em grau menor para os géis de clorexidina e placebo. O estudo indicou que 
a escovação meticulosa da prótese é efetiva no controle do biofilme e que a solução química de imersão não teve efeito aparente.

Manderson e Brown ${ }^{61}$ (1978), em experimento laboratorial e clínico, compararam dois produtos de higiene, um à base de ácido sulfâmico (Valdent - Reckitt and Colman Products Ltd.) e outro à base de perborato alcalino (Steradent - Reckitt and Colman Products Ltd.). No estudo laboratorial foram avaliados os efeitos dos higienizadores nos materiais constituintes das próteses (resinas termopolimerizável e autopolimerizável, dentes artificiais, metais, forradores e condicionadores de tecido). No estudo clínico foram selecionados 60 pacientes, que foram instruídos a imergir suas próteses em $150 \mathrm{ml}$ de água a $55^{\circ} \mathrm{C}$ com Valdent ou Steradent dissolvido, por 20minutos. As próteses foram fotografadas antes e após a limpeza. Foi aplicado um sistema de escores para avaliar a eficácia dos higienizadores: 1-sem diferença, 2-alguma limpeza aparente, 3-quase limpa e 4-totalmente limpa. Os resultados das análises clínicas e laboratoriais mostraram efetividade do produto à base de ácido sulfâmico (Valdent), quando na presença de depósitos de cálculos, sem danos aparentes aos materiais constituintes das próteses.

Shannon e Starcke ${ }^{96}$ (1978) conduziram testes laboratoriais e clínicos para testar a habilidade de remoção de biofilme de produtos de higiene específicos para limpeza de próteses. Amostras de resina acrílica foram imersas em: Polident Tablets (Block Drug Co.), Mersene (Colgate-Palmolive Co.), Sonac Solution e Sonac Electrosonic (Cooper Laboratories), VA cleanser (novo higienizador de prótese desenvolvido para imersão) e água deionizada (controle), com imersões de 15 minutos. O biofilme foi evidenciado antes e após as imersões nas soluções higienizadoras e quantificado por meio da atribuição de escores. Um estudo clínico preliminar foi realizado comparando a habilidade do higienizador Purify (Johnson \& Johnson), com Mersene e o higienizador VA. Quatro pacientes hospitalizados utilizaram os produtos para imersão das próteses durante a noite por um período de 10 dias. 
Os tratamentos com Mersene e higienizador VA foram mais efetivos que com o Polident. A solução Sonac isolada e utilizada no aparelho Sonac Electrosonic foi mais efetiva que a imersão em Polident, porém menos eficaz que Mersene e VA. No estudo clínico, as imersões durante a noite em Mersene e VA também foram efetivas quanto à limpeza das próteses.

Abelson $^{1}$ (1981) testou a habilidade de remoção do biofilme da prótese de um novo aparelho ultra-sônico (Sonic Scrub) usado com água e com produtos à base de peróxido alcalino: Efferdent (Warner Lambert Co.) e Polident (Block Drug Co.). Próteses de 18 voluntários foram examinadas, limpas e polidas. Os voluntários não higienizaram suas próteses 3 dias antes de cada sessão ( 3 sessões de testes). Foram utilizados 3 critérios de atribuição de escores (1- número de dentes apresentando biofilme, 2- índice de biofilme em dentes selecionados, e 3- índice de biofilme aplicado na superfície tecidual das próteses) antes e após a utilização dos produtos de higiene. Os resultados mostraram superioridade do ultrasom (dentes e base) com água, quando comparado aos higienizadores de imersão à base de peróxido alcalino (Efferdent e Polident).

Walker et al. ${ }^{107}$ (1981) testaram um agente antimicótico (Anfotericina - Squibb Ltd.) e um higienizador de prótese à base de peróxido (Steradent - Reckitt \& Colman Ltd.) no tratamento da Estomatite Protética em 49 pacientes por um período de 5 semanas. Foram avaliados os níveis de biofilme, grau de inflamação da mucosa e densidade de leucócitos, por meio de escalas de atribuição de escores. Os pacientes foram instruídos a escovar suas próteses com água de torneira após as refeições e a utilizar um dos tratamentos: 1)Anfotericina/Steradent; 2) Anfotericina/ Placebo; 3) Placebo/Steradent, e 4) Placebo/Placebo. Os resultados mostraram que nenhum dos agentes foi mais efetivo do que os placebos na redução de Candida albicans, na inflamação da mucosa ou na prevenção do acúmulo de biofilme. Segundo os autores, a estomatite protética pode ser efetivamente tratada por remoção mecânica do biofilme da prótese. 
Augsburger e Elahi ${ }^{11}$ (1982) estudaram a eficiência de limpeza de 7 higienizadores químicos de imersão de próteses em um grupo de 110 pacientes usuários de próteses totais de resina acrílica. Os produtos empregados foram: Denalan (Whitehall Laboratories); Mersene (Colgate-Palmolive Co.); Efferdent e o new Efferdent (Warner-Lambert Co.); Polident (Block Drug Co.) e o old Kleenite e o new Kleenite (Vick Chemical Co.). Todas as próteses tinham acúmulos de biofilme, sendo que foram limpas e os pacientes instruídos a não limparem suas próteses por 24 horas antes do início do estudo. As próteses foram evidenciadas e examinadas quanto à presença de biofilme e manchas, por meio de escala de atribuição de escores. As próteses foram então colocadas nas soluções higienizadoras de acordo com as instruções dos fabricantes por 10 minutos, e em seguida, foram atribuídos novamente escores. Os autores concluíram que o período de imersão utilizado (10 minutos) não foi efetivo na remoção do biofilme, sendo recomendado períodos mais longos de imersão, associados à escovação mecânica. O Mersene e o novo Kleenite foram os mais efetivos, tanto para a remoção de manchas, como para remoção de biofilme.

Kempler et al. ${ }^{46}$ (1982) avaliaram a eficácia de várias concentrações de hipoclorito de sódio na remoção de depósitos acumulados em próteses parciais e totais, comparando-os com higienizadores disponíveis no mercado. Foram utilizados os seguintes higienizadores: Polident, Efferdent, Denalan, Hipoclorito de sódio (Clorox) 1\%, Hipoclorito de sódio 5\%, Hipoclorito de sódio 25\%, Hipoclorito de sódio 50\% e água de torneira. Foram seguidas as instruções dos fabricantes na higienização com os produtos comerciais. Os grupos de hipoclorito de sódio e o grupo controle foram imersos por 10 minutos. As próteses foram fotografadas e avaliadas por escala de pontos. As soluções de hipoclorito de sódio apresentaram melhor limpeza das próteses, quando comparadas aos produtos comerciais testados. As soluções de hipoclorito de sódio completaram a limpeza dentro de 2 a 3 minutos, 
mas as próteses permaneceram em solução por 10 minutos. A solução de hipoclorito de sódio $50 \%$ mostrou-se mais efetiva que os agentes de limpeza avaliados.

Ghalichebaf, Graser e Zander ${ }^{38}$ (1982) compararam a eficácia de quatro higienizadores do tipo imersão: Mersene (Colgate-Palmolive Co.), Polident (Block Drug Co.), Efferdent (Warner-Lambert Co.) e Clorox (The Clorox Co.) e Calgon (Beecham Products), sendo o ingrediente ativo do Clorox o hipoclorito de sódio 5,25\%. Foram selecionados 15 pacientes usuários de próteses totais maxilares e mandibulares. Uma cavidade $(1 \mathrm{~cm} \mathrm{x} 1 \mathrm{~cm})$ foi confeccionada na região da tuberosidade das próteses superiores, sendo posteriormente moldada para confecção de encaixes de resina acrílica removíveis. Os encaixes foram esterilizados (autoclave) e inseridos na região preparada. Após o uso das próteses por 24 horas, não sendo realizado nenhum procedimento de limpeza, as próteses foram coradas com eritrosina $(5 \%)$ e fotografadas sob condições padronizadas. As próteses foram imersas nas soluções higienizadoras por 15 minutos, e foram novamente coradas, fotografadas e analisadas em diapositivos projetados em uma tela quadriculada para o cálculo da porcentagem da superfície corada. O número de áreas evidenciadas em relação à área total forneceu a porcentagem da superfície corada pelo biofilme. Os resultados mostraram a eficácia do Mersene e do Clorox-Calgon, que pode estar relacionada ao $\mathrm{pH}$, que é maior do que no Efferdent e Polident, sendo que também pode estar relacionado ao conteúdo de hipoclorito de sódio presente no Mersene.

DePaola, Minah e Elias ${ }^{32}$ (1984) testaram a atividade antimicrobiana de 14 produtos (higienizadores de prótese, anti-sépticos orais e desinfetantes) disponíveis no mercado contra microrganismos patogênicos isolados de próteses de 16 pacientes com câncer. Os microrganismos patogênicos foram: Pseudomonas aeruginosa, Klebsiella pneumoniae, Enterobacter cloacae, Escherichia coli, Staphylococcus aureus, Candida albicans, e Torulopsis glabrata. A atividade antimicrobiana de cada um dos seguintes agentes foi 
avaliada: Kleenite (Vicks Toiletry Products Div.), Efferdent (Warner-Lambert Co.), Polident (Block Drug Co.), Mersene (Colgate-Palmolive Co.), Gluconato de clorexidina a 1\% (Stuart Pharmaceuticals), Chloraseptic (Norwich-Eaton Pharmaceuticals), Listerine (Warner-Lambert Co.), Listermint (Warner-Lambert Co.), Greene Mint (Block Drug Co.), Signal (Lever Brothers), Scope (Proctor and Gamble Co.), Lavoris (Block Drug Co.), Cepacol (Merril National Laboratories), Betadine Mouthrinse Gargle 2\% (The Purdue Frederick Company). Seis agentes: Kleenite, Efferdent, Polident, Listerine, Chloraseptic e Gluconato de clorexidina $1 \%$ inibiram todos os microrganismos em uma diluição 1:4.

Rudd et al. ${ }^{91}$ (1984) avaliaram a ação bactericida do hipoclorito de sódio 5,25\% (Clorox) na esterilização de próteses totais e determinar o tempo necessário de imersão para a obtenção desse efeito. Confeccionaram 20 próteses superiores que posteriormente foram cortadas ao meio. Cada parte foi contaminada com os microrganismos Staphylococcus aureus, Bacilus subtilis (forma vegetativa e esporos), Candida albicans, Pseudomonas aeruginosa e Streptococcus (Enterococcus), em seguida, submetidas à imersão na solução por 1,3 e 5 minutos. Concluíram que a imersão por 5 minutos em hipoclorito de sódio 5,25\% (Clorox) proporcionou esterilização contra uma variedade de microrganismos, sendo improvável que imersões ocasionais de 5 minutos afetem o material das próteses.

Tarbet et al. ${ }^{103}$ (1984) compararam a eficácia na limpeza de prótese de dois métodos de higienização. Um dos métodos consistiu do uso de dois produtos para imersão: Efferdent (Warner-Lambert Co.) e Polident (Block Drug Co.). O outro método envolveu a escovação com uma pasta de baixa abrasividade (Complete, Richardson-Vicks Inc.). O estudo envolveu 75 usuários de próteses superiores que usaram os métodos de higienização por 12 semanas, distribuídos nos três grupos, de acordo com as instruções dos fabricantes. As próteses foram avaliadas semanalmente por meio da atribuição de escores. Os resultados demonstraram a efetividade do método escovação com pasta na remoção do biofilme da prótese. Contudo, a 
escovação não promove uma limpeza adequada de todas as regiões da prótese, sendo então indicada imersão ocasional em tabletes efervescentes.

Palenik e Miller $^{78}$ (1984) compararam a capacidade de remoção de biofilme de dois aparelhos ultra-sônicos (Sonic Scrub, Clairol Inc., e Model CU-6 Ultrasonic Cleaner, Branson Cleaning Equipment Co.) com um agente de imersão à base de peróxido alcalino (Efferdent, Warner-Lambert Co.). Próteses totais superiores de resina acrílica foram limpas e esterilizadas. Utilizou-se Streptococcus mutans para formação de biofilme na superfície do acrílico. Após o acúmulo do biofilme (18 a 20 horas), as próteses foram evidenciadas. Para a atribuição de escores, cada prótese foi dividida em três grandes áreas: dentes, palato e superfície tecidual. Cada um desses grandes segmentos foi posteriormente dividido em 40 partes iguais que foram analisados individualmente quanto ao biofilme visível, e somados para obtenção de uma média. O aparelho de ultra-som Model CU-6 foi utilizado com $250 \mathrm{ml}$ de água $\left(40^{\circ} \mathrm{C}\right.$ a $\left.42^{\circ} \mathrm{C}\right)$ e $27,5 \mathrm{ml}$ de um enxaguatório bucal (Lavoris, Richardson-Vick Corp.) por 5, 10 ou $15 \mathrm{~min}$. O Efferdent foi adicionado a $200 \mathrm{ml}$ de água quente $\left(48^{\circ} \mathrm{C}\right)$ por $12 \mathrm{~min}$. Água fria $(250 \mathrm{ml})$ a $13^{\circ} \mathrm{C}$ foi misturada com $27,5 \mathrm{ml}$ de enxaguatório bucal e colocada no aparelho Sonic Scrub's por 15 minutos. O método ultra-sônico mostrou-se mais efetivo que o efervescente, sendo o modelo Branson CU-6 mais efetivo.

Moore, Smith e Kenny ${ }^{70}$ (1984) realizaram um estudo em duas etapas para comparar a eficácia de 8 produtos de limpeza de prótese. Na primeira etapa, foi avaliada a eficácia dos produtos em culturas de Candida albicans, e na segunda foi comparada a eficácia na remoção ou eliminação de microrganismos aeróbios, anaeróbios e leveduras das próteses. Na primeira parte foi realizado um estudo laboratorial utilizando os higienizadores peróxidos alcalinos Denalan (Whitehall Laboratories), Efferdent (Warner-Lambert Co.), Kleenite (RichardsonMerrill), Mersene (Colgate-Palmolive Co.) e Polident (Block Drug Co.), os hipocloritos alcalinos Clorox/Calgon (The Clorox Co.; Beecham Products) e um produto de composição 
desconhecida (Miller's - Bell Dental Laboratory). Os higienizadores foram testados em 1/4, 1/2 e nas concentrações recomendadas pelos fabricantes. Amostras foram colhidas após 15, 30 e 60 minutos de exposição. Determinou-se que os produtos Mersene, Clorox/Calgon e Miller's tiveram atividade fungicida semelhante. Os produtos Efferdent, Polident e Denalan foram menos efetivos. Um segundo estudo clínico foi realizado com 12 pacientes, que foram instruídos a usar os higienizadores (Mersene, Polident, Efferdent, Miller's, Kleenite, e Clorox/Calgon) e a escovação com sabão Ivory (Proctor and Gamble) e água de torneira. As próteses foram imersas por 30 minutos. Os resultados mostraram que Miller's e Kleenite foram os agentes mais efetivos. A escovação da prótese com água e sabão combinada com a imersão em Mersene foi efetiva, mas em um nível menor. Embora o Clorox/Calgon tenha se mostrado efetivo na eliminação de leveduras em condições laboratoriais, ele não foi efetivo em condições clinicas.

Watkinson, McCreight e Wornock ${ }^{108}$ (1985), investigaram o efeito do hipoclorito como higienizador de prótese quanto à persistência de C. albicans na cavidade oral de pacientes com estomatite protética. Cinco participantes do estudo foram instruídos a remover suas próteses durante a noite e imergí-las em solução de hipoclorito alcalino (Dentural, McCarthys Ltd.) por 2 semanas. Amostras microbianas foram colhidas do palato e da superfície da prótese. Em 3 dos 5 pacientes, houve reincidência da cepa C. albicans. Segundo os autores, os resultados sugerem que o biofilme da prótese é constantemente recolonizado por leveduras da mucosa.

Minagi et al. ${ }^{68}$ (1987) compararam a eficácia de agentes higienizadores à base de enzimas com um higienizador à base de peróxido alcalino. Foram utilizadas duas próteses totais superiores e uma inferior, sendo as mesmas seccionadas em vários fragmentos $(5 \mathrm{~cm} \mathrm{x}$ $5 \mathrm{~cm}$ ) e distribuídos em 4 grupos, consistindo de um grupo controle (imersão em água destilada) e três grupos de higienizadores: Pika (Rohto Pharmaceutical Co. - enzima 
proteinase e glucanase), Polident (Block Drug Co. - enzima proteinase) e Efferdent (WarnerLambert Co. - peróxido). As amostras foram imersas nas soluções por 6 horas a $20^{\circ} \mathrm{C}$. Os autores avaliaram a porcentagem de acúmulo de biofilme de cada amostra, utilizando analise gráfica computadorizada, sendo também analisado a atividade antifúngica. Os resultados mostraram uma superioridade do agente higienizador Pika quanto à avaliação da atividade antifúngica e ao procedimento de limpeza. O produto Polident também removeu efetivamente o biofilme.

McGowan, Shimoda e Woolsey ${ }^{66}$ (1988) determinaram os efeitos de diferentes concentrações de hipoclorito de sódio e tempos de imersão em ligas Ticonium (Ticonium Co.) e Vitallium (Howmedica Inc.). O teste foi dividido em duas fases: na fase I, hipoclorito de sódio $5,25 \%$ foi diluído em água destilada para obtenção de soluções nas concentrações de $0,5 \%, 1 \%, 2 \%, 3 \%, 4 \%$, e 5,25\%. Água destilada foi usada como controle. Um grupo de amostras metálicas foi imerso por 30 minutos e outro por 5 minutos. Após a retirada das amostras das soluções de imersão, foram realizadas culturas, e análises clínicas do manchamento e corrosão em microscópio eletrônico de varredura. Na fase II, amostras foram imersas em hipoclorito de sódio $5,25 \%$ por $1,3,5,10,15$ e 30 minutos, bem como por 24 horas. Os resultados mostraram que amostras destes metais imersas em hipoclorito de sódio 2\% por no mínimo 5 minutos ou em hipoclorito de sódio $5,25 \%$ por no mínimo 3 minutos foram esterilizadas e não ocorreram manchamento e corrosão. O uso adequado de alvejante doméstico é um método efetivo e econômico para esterilização de próteses parciais removíveis com estruturas de ligas níquel-cromo ou cromo-cobalto.

Dills et al. ${ }^{35}$ (1988) compararam a habilidade de dois métodos populares de higiene de prótese (escovação e imersão) quanto à atividade antimicrobiana. Foram realizados dois experimentos clínicos utilizando uma pasta de prótese abrasiva e um produto químico para imersão (peróxido alcalino). No primeiro experimento, 14 pacientes foram instruídos a não 
realizar nenhum procedimento de higienização de suas próteses por 48 horas, e quando do inicio do tratamento, foram instruídos a limpar suas próteses por um dos seguintes tratamentos: 1)Escovação (Curv-Clean denture brush, Brimms Inc.) com pasta especifica para prótese (Dentu-Cream toothpaste, Block Drug Co.) por 30 segundos, 2)imersão em solução de peróxido alcalino (Efferdent denture cleanser, Warner-Lambert Co.) por 12 minutos a $45^{\circ} \mathrm{C}$, 3)Escovação com a pasta especifica para prótese seguida por imersão em Efferdent e 4)Sem tratamento. No segundo experimento, 16 pacientes não realizaram nenhum procedimento de limpeza da prótese por 72 horas antes do experimento, e realizaram os mesmos tratamentos do primeiro experimento. Foram realizados esfregaços das superfícies internas das próteses e semeaduras em meios de cultura. Os resultados mostraram uma superioridade do método de imersão em solução química, mesmo quando comparado com o método combinado (escovação e imersão). Estes resultados sustentam a necessidade do uso de um agente higienizador químico em adição à escovação com uma pasta adequada para prótese para que bons resultados sejam alcançados.

Bell et al. ${ }^{18}$ (1989) compararam a capacidade biocida do hipoclorito de sódio 5,25\% (diluído 1:10) e dióxido de cloro frente a eliminação de microrganismos patogênicos em amostras de resinas acrílicas. Amostras de resina acrílica (Accelar 20, Columbia Dental) foram confeccionadas, esterilizadas e inoculadas com Staphylococcus aureus, Candida albicans ou Escherichia coli na presença de material orgânico. Uma amostra foi usada como controle para cada microrganismo. As amostras foram desinfetadas em dióxido de cloro (Alcide LD, Alcide Corp.) e hipoclorito de sódio (Purex Corp.), diluído (1:10). Como controle empregou-se solução salina. As amostras foram imersas nas soluções por 30 segundos, 1, 2, ou 4 minutos. Após a desinfecção, foram neutralizadas e incubadas por 72 horas para verificar a viabilidade dos organismos. Os resultados mostraram uma diferença entre os produtos testados quando matéria orgânica estava presente. A solução de dióxido de cloro foi efetiva 
frente a microrganismos com 2 minutos, sendo que o hipoclorito de sódio realizou a desinfecção com 4 minutos. Com 2 minutos, ambos os desinfetantes foram efetivos na eliminação de C. albicans.

Raab et al. ${ }^{88}$ (1991) compararam a eficácia de métodos de higienização (efervescente e limpeza ultra-sônica) na habilidade de remoção de depósitos superficiais como biofilme, cálculo e pigmentação de cigarro. Foram preparadas 30 amostras provenientes de 10 próteses totais seccionadas. Uma amostra de cada prótese foi mantida sem nenhum procedimento de limpeza, para posterior comparação com outros dois métodos empregados: 1)Imersão em higienizador efervescente (Extra Strength Efferdent; Warner-Lambert) e 2) ultra-som (L \& R Transister/Ultrasonic T-28; L \& R Mfg.Co.) associado com água e higienizador, por 90 segundos. As amostras foram examinadas em microscópio eletrônico de varredura (Phillips 500 - Phillips Electronic Instruments). Foram realizadas fotografias das regiões representativas de cada amostra, sendo cada uma graduada em escala de 1 a 10 , de acordo com a porcentagem da área recoberta com os depósitos. Os resultados mostraram que houve diferença significativa entre os três tratamentos (controle, imersão e ultra-som), com superioridade do ultra-som.

Chan et al. ${ }^{24}$ (1991) compararam a eficácia de uma solução para imersão (Efferdent Extra-Strenght Denture Cleanser Tablets, Warner-Lambert) e uma pasta para prótese (Advanced Fórmula Dentu-Creme, Block Drug, Canadá), na remoção e eliminação de bactérias do biofilme de próteses removíveis. Participaram do estudo 18 pacientes que não realizaram nenhum procedimento de limpeza por 48 horas e foram distribuídos em um dos seguintes tratamentos: 1)Sem tratamento, 2)Escovação com pasta para prótese por 30 segundos, 3)Imersão em Efferdent por 12 minutos em água a $45^{\circ} \mathrm{C}$, e 4)Escovação seguida de imersão em Efferdent. Os tratamentos duraram duas semanas. Colheitas microbiológicas foram realizadas antes e após cada tratamento. Os resultados mostraram que a imersão foi tão 
efetiva quanto o tratamento combinado (imersão e escovação) na remoção e eliminação de fusobactérias. O tratamento combinado foi mais efetivo na remoção de bactérias facultativas e anaeróbias. O tratamento combinado removeu resíduos alimentares e outros materiais indesejados, sendo o método preconizado pelos autores para higiene de prótese total.

Nakamoto; Tamamoto; Hamada ${ }^{71}$ (1991), compararam a eficácia de limpeza de higienizadores contendo enzimas e um higienizador do tipo peróxido alcalino (sem a presença de enzimas) frente a cepas de Candida albicans. Foram empregados higienizadores com enzimas (Pika - Rohto Pharm. Co., Ltd.; Liodent - Lion Corporation Tokyo; Dr. Health Sunstar Incorporation; Polident - Kobayashi Block Co., Ltd.) e peróxidos alcalinos (Polident Kobayashi Block Co., Ltd.). As soluções foram preparadas pela dissolução de 1 tablete em $200 \mathrm{ml}$ de água destilada durante 120 minutos. Os resultados mostraram que os cinco higienizadores testados mostraram excelentes resultados quanto à remoção de Candida albicans.

Basson, Quick e $\operatorname{Thomas}^{15}$ (1992) avaliaram produtos caseiros não especificamente comercializados para limpeza de prótese, mas que poderiam ser efetivos quando utilizados para esta finalidade. Foram confeccionadas placas acrílicas palatinas para 6 indivíduos dentados, as quais foram usadas durante o dia e imersas em soluções higienizadoras durante a noite. As soluções desinfetantes utilizadas foram: 1) Milton 4\% $(\mathrm{NaOCl} 0,04 \%+\mathrm{NaCl}$ $0,66 \%) ; 2)$ Milton 1,2\% ( $\mathrm{NaOCl} 0,012 \%+\mathrm{NaCl} 0,19 \%) ; 3)$ Vinagre não diluído; 4) vinagre 50\% (diluído); 5) sal ( $\mathrm{NaCl}) 20 \%$; e 6) água de torneira (controle). Cada produto foi usado por 7 dias consecutivos e, posteriormente, os encaixes foram removidos, inspecionados visualmente e realizou-se a contagem de bactérias viáveis. Todas as soluções testadas resultaram em uma significante redução do número de bactérias quando comparadas ao controle em água. As soluções com maior e menor efetividade foram a solução de Milton e o vinagre não diluído, respectivamente. A imersão noturna das placas em uma solução fraca de 
hipoclorito $(0,012 \%$ e $0,04 \%)$ resultou em significante redução do número de bactérias e de biofilme.

Chau et al. ${ }^{25}$ (1995) avaliaram o grau de penetração de bactérias em resinas acrílicas bem como efetividade de 3 desinfetantes. Foram confeccionadas amostras das seguintes resinas acrílicas: Lucitone 199 termopolimerizável (Dentsply), resina ortodôntica (The L.D. Caulk Co. Division of Dentsply International Inc.), e material de reparo autopolimerizável (L.D. Caulk Co.). As amostras foram imersas em cultura de 4 bactérias (S. aureas, E. coli, P. Aeruginos e Streptococcus pneumonia) por 24 horas, sendo em seguida removidas do meio de cultura, enxaguadas em solução salina estéril e imersas em uma das três soluções desinfetantes: 1)Biocide (Biotrol International), imersão por 10 minutos em solução de Biocide $0,48 \%$ em água deionizada quente $\left(\geq 20^{\circ} \mathrm{C}\right) ; 2$ )Alcide LD (Alcide Corp.), imersão por 3 minutos; 3)Hipoclorito de sódio (James Austin Co.), imersão por 10 minutos em hipoclorito de sódio 5,25\% e água deionizada (1:10), e 4) Solução salina estéril 0,9N, imersão controle 10 minutos. Em seguida, foram realizados testes microbiológicos. Os dados obtidos confirmaram a penetração de bactérias no interior das resinas acrílicas e a efetividade da imersão em hipoclorito de sódio a $0,525 \%$ por 10 minutos.

McCabe, Murray e Kelly ${ }^{65}$ (1995) compararam a eficácia de dois produtos para imersão e escovação (pasta de dentes, sabão e água), na remoção de manchas, biofilme e cálculo das próteses. Os métodos utilizados foram: 1) Tablete experimental (Reckitt $\mathrm{GmbH}$ ), diluído em água $35^{\circ} \mathrm{C}$ por 10 minutos, sem escovação; 2) Steradent (Reckitt $\mathrm{GmbH}$ for Reckitt \& Colman Products Ltd.), diluído em água a $50^{\circ} \mathrm{C}$ por 10 minutos seguido por leve escovação; 3) Colgate Anti-Tartar (Colgate-Palmolive Ltd.), pasta de dentes usada com escova de dentes por 2 minutos e 4) Cussons Imperial Leather (Cussons U.K. Ltd.), pasta de dentes usada com escova de dentes por 2 minutos. Os métodos foram testados alternadamente durante 4 semanas. As próteses foram inicialmente coradas e posteriormente aplicado um sistema de 
escores para manchas, cálculos e biofilme. Cada prótese foi higienizada por um profissional com um dos métodos testados e a evidenciação e atribuição de escores novamente realizadas. A imersão em Steradent foi a forma mais efetiva para remoção do biofilme e manchas. Não houve diferença entre os produtos quanto à capacidade de remoção de cálculo.

Webb et al. ${ }^{111}$ (1995) avaliaram a eficácia in vitro do hipoclorito de sódio na esterilização de próteses acrílicas e na adesão de espécies de Candida em superfícies orais. Foi utilizada solução antibacteriana de Milton (Proctor \& Gamble Austrália Pty. Ltd.), sendo avaliado o crescimento de Candida na presença ou ausência do hipoclorito. O hipoclorito de sódio reduziu a adesão de várias espécies de Candida. Concluíram que o hipoclorito na concentração inibitória mínima combate à adesão de espécies de Candida, mas não afetam suas características patogênicas. O hipoclorito de sódio pode funcionar como um efetivo agente antifúngico, quando usado para imersão de próteses em caso de estomatite de dentadura.

Keng e $\operatorname{Lim}^{47}$ (1996) avaliaram a distribuição de biofilme em 42 próteses totais (superiores e inferiores) e a eficácia de um agente higienizador de imersão à base de perborato (Polident - Block Drug). Cinco regiões das próteses (palatina, superfície interna, labial anterior, bucal direita e esquerda) foram coradas e fotografadas. As próteses foram imersas em $200 \mathrm{ml}$ de água de torneira com o tablete de Polident por 20 minutos, seguindo as instruções dos fabricantes. As próteses foram coradas e fotografadas novamente, e avaliadas por meio de escala de atribuição de escores. Os resultados mostraram que o biofilme tende a se acumular mais facilmente na superfície interna da prótese, do que nas superfícies polidas. O uso do higienizador de imersão apresentou efetividade limitada, uma vez que houve pequena redução dos níveis de biofilme.

Kulak et al. ${ }^{51}$ (1997) compararam a eficácia da escovação e da imersão em soluções químicas, na remoção da contaminação superficial de próteses totais superiores de 5 
pacientes. A região posterior das próteses foi seccionada em 8 amostras de $1 \mathrm{~cm}^{2}$. Uma amostra foi deixada sem tratamento como controle. Seis amostras de cada prótese foram imersas durante o período noturno em soluções efervescentes (Corega - Stafford - Miller Ltd.; Dentipur - Helago - Pharma D - 5300; Fittydent - Mag. Hoeveler $\varepsilon$ Co.), hipoclorito de sódio a 5\%, Savlon (Zeneca Abdi-Irahim Ilaç Tic.) e Ipanol (Procter $\epsilon$ Gamble). Uma das amostras foi submetida à escovação com uma pasta específica para prótese (Ipana - Procter $€$ Gamble) por 30 segundos. As amostras foram avaliadas em microscopia eletrônica de varredura (Joel JSM-5200). Os resultados mostraram que as soluções de hipoclorito de sódio 5\% e Savlon foram as mais efetivas na remoção de contaminantes. Os autores concluíram que a imersão da prótese durante a noite em solução de Savlon foi o mais efetivo de todos os procedimentos.

Baysan, Whiley e Wright ${ }^{17}$ (1998) determinaram a eficácia da energia de microondas na desinfecção de material de forramento macio de longa-duração Molloplast - B (Detax, Karl Huber GmbH and Co. KG) contaminado com Candida albicans ou Staphylococcus aureus. Amostras do material de forramento foram contaminadas com os microrganismos, submetidos à desinfecção em: 1) energia de microondas a $650 \mathrm{~W}$ por 5 minutos, 2) secas a temperatura ambiente durante a noite (5 horas), e 3) imersão em solução de hipoclorito de sódio (Milton, Procter and Gamble Health and Beauty Ltd.) diluído 1:50 durante a noite (5 horas). Após os procedimentos de desinfecção, foi avaliada a redução dos microrganismos. Concluiu-se que a desinfecção do material Molloplast - b contaminado com Candida albicans ou Staphylococcus aureus foi melhor e mais efetiva quando da imersão em solução diluída de hipoclorito de sódio.

Webb et al. ${ }^{109}$ (1998), testaram in vitro a eficácia de dois métodos de esterilização de prótese: irradiação por microondas e imersão em hipoclorito de sódio. Vinte próteses totais superiores de resina acrílica foram preparadas para análise microbiológica, sendo que 10 
foram inoculadas com C. albicans e 10 com Streptococcus gordonii. Cinco próteses de cada grupo foram levadas ao forno de microondas. A análise microbiológica mostrou que as próteses inoculadas tornaram-se estéreis depois de 6 minutos de irradiação na potência média, sendo também examinadas em microscópio eletrônico de varredura. As próteses também foram imersas por 8 horas em solução de hipoclorito de sódio (Milton, Procter \& Gamble) diluída a $0,0125 \%(1,25 \mathrm{ml}$ de hipoclorito de sódio/98,75 $\mathrm{ml}$ de água destilada) ou $0,02 \%$ (2 $\mathrm{ml}$ de hipoclorito de sódio $/ 98 \mathrm{ml}$ de água destilada) e próteses utilizadas como controles foram imersas em água destilada. Análises microbiológicas mostraram que próteses inoculadas com C. Albicans tornaram-se estéreis e aquelas inoculadas com Streptococcus gordonii não se tornaram estéreis. De acordo com os resultados a irradiação por microondas é um efetivo método de esterilização de prótese, sendo mais efetivo que a imersão em hipoclorito de sódio. Contudo, os níveis de microorganismos residuais não viáveis na superfície da prótese são reduzidos pelo hipoclorito.

Sesma et al. ${ }^{95}$ (1999), investigaram a eficácia de 3 métodos de higienização de próteses parciais removíveis por meio da análise em microscópio eletrônico de varredura. Foram avaliados três métodos por 10 pacientes usuários de próteses parciais removíveis: escova de dentes com dentifrício; escovas de dentes com dentifrício associado a imersão em produto químico a base de perborato de sódio (Limpador Efervescente - farmácia de manipulação Fórmula e Ação) e escovas de dentes com dentifrício associado a aplicação de digluconato de clorexidina a $2 \%$ Os pacientes utilizaram cada método por uma semana. Após 7 dias, amostras foram obtidas da região interna da sela das próteses para análise em microscópio eletrônico de varredura. Observou-se que o uso do método mecânico associado à imersão da prótese no produto químico efervescente promoveu uma melhor higienização em relação ao uso do método mecânico. Mas a aplicação da clorexidina a $2 \%$ na parte interna da sela da 
prótese associada ao método mecânico foi melhor que os métodos anteriores. Concluiu-se que nenhum dos métodos conseguiu eliminar toda a placa bacteriana da superfície das próteses.

Sheen e Harrison ${ }^{98}$ (2000) avaliaram o desenvolvimento de um novo método para avaliar níveis de biofilme em próteses utilizando imagem digitalizada, juntamente com um método visual de atribuição de escores. Foram selecionados 35 pacientes que foram distribuídos em dois grupos: 1) Imersão das próteses em um novo higienizador Fixodent (Procter and Gamble Technical Centres Ltd.) contendo polímero de silicone, e 2) Imersão das próteses em água. Os pacientes foram instruídos a dissolver 1 tablete do higienizador em água $\left(35^{\circ} \mathrm{C}\right.$ a $\left.45^{\circ} \mathrm{C}\right)$ em um aparelho denominado Denturette (Procter and Gamble Technical Centres Ltd.), seguido de escovação com água por 30 segundos uma vez ao dia. O período experimental foi de 14 dias e os níveis de biofilme foram avaliados no inicio, no $2^{\circ}$ e $14^{\circ}$ dias por imagem digitalizada e atribuição de escores. Os resultados mostraram que ambos os métodos foram capazes de quantificar os níveis de biofilme e que o agente higienizador foi efetivo na prevenção do acumulo de biofilme.

Gornitsky et al. $^{40}$ (2002) avaliaram a eficácia de três higienizadores na redução de Candida spp. e bactérias das superfícies das próteses, remoção de resíduos alimentares, redução de manchas e biofilme, em próteses de pacientes hospitalizados. Foram comparados três higienizadores: Denture Brite (Advantage Products), Polident Overnight (GlaxoSmithKline Consumer Health Group) e Efferdent New Concentrated Blue Tablet (Pfizer Consumer Health Care) em 27 pacientes idosos hospitalizados. A imersão em água foi usada como controle. Os higienizadores foram empregados por períodos de 1 semana, sendo que as próteses eram imersas no higienizador Denture Brite por 20 minutos por dia, e nos higienizadores Polident Overnight e Efferdent New Concentrated Blue Tablet, durante a noite. Amostras microbiológicas foram obtidas antes e após 3 semanas de uso dos higienizadores. $\mathrm{O}$ acúmulo de biofilme foi verificado por meio de fotografia das próteses e atribuição de 
escores. Os resultados mostraram que os produtos apresentaram resultados similares quanto à eficácia na redução de biofilme, manchas e resíduos alimentares e que reduziram significantemente o número de microrganismos das próteses.

Garcia Junior $^{37}$ (2002), avaliou a eficácia de hipoclorito de sódio 1\% (Biodinâmica Química e Farmacêutica Ltda.), hipoclorito de sódio 2\% (Biopharma) e glutaraldeído 2\% (Cidex, Johnson \& Johnson Produtos Profissionais Ltda.) frente aos microrganismos Staphylococcus aureus, Pseudomonas aeruginosa, Enterococcus faecalis, Streptococcus mutans e Candida albicans na desinfecção da superfície externa e interna de uma resina acrílica termopolimerizável (Lucitone 550, Dentsply). Corpos-de-prova foram imersos nas soluções por 5, 10 e 15 minutos. Os resultados mostraram que 10 minutos de imersão foi adequado para a desinfecção da superfície externa da resina acrílica, sendo que a rugosidade não teve influência. A desinfecção por 15 minutos com hipoclorito de sódio $1 \%$ e glutaraldeído $2 \%$ foram eficazes frente a maioria dos microrganismos presentes internamente na resina acrílica.

Jagger et al. ${ }^{43}$ (2002) avaliaram a efetividade de 7 higienizadores de próteses quanto à remoção de manchas da resina acrílica. Foram confeccionadas amostras de resina acrílica Perspex com superfícies polidas e rugosas. Usando um espectrofotômetro (Perkin-Elmer) a densidade óptica de cada amostra foi determinada antes do tratamento. As amostras foram manchadas por meio da imersão em solução de chá por 1 hora. A densidade óptica foi novamente determinada. As amostras foram imersas nas soluções de limpeza por 5 minutos: Dentural (Martindale Pharmaceuticals), Dentu Creme (Stafford Miller), Denclen (Proctor and Gamble), Boots Denture Cleaning Powder (Boots), Steradent (Reckitt Colman), Boots Denture Toothpaste (Boots), Fixodent Tablets (Proctor and Gamble) e água (controle). Os higienizadores contendo hipoclorito e Boots Denture Cleaning Powder foram mais efetivos na remoção de manchas. Os resultados mostraram que irregularidades e porosidades presentes na 
superfície da prótese reduzem a atividade dos agentes de limpeza, aumentando a retenção de biofilme e manchas.

Nikawa et al. ${ }^{77}$ (2003) analisaram a formação de biofilme e a presença de Candida albicans na superfície de materiais de base deteriorados por higienizadores de prótese. Foram empregados 2 materiais de forramento acrílico autopolimerizante (Soften e Nissin Soft Reverse), 4 materiais de forramento de silicone autopolimerizáveis (Mollosil, Evatouch, Tokuyama Soft Relining, e GC Denture Relining), um forrador silicone termopolimerizável (Molloplast B) e uma resina acrílica termopolimerizável (Bio resin). Tais materiais foram artificialmente deteriorados pela imersão em 5 higienizadores: Steradent (Reckitt $\varepsilon$ Colman peróxido alcalino), Correct (Shionogi Chem. Co. - peróxido neutro com enzima), Polident (Kobayashi Block Co. - peróxido neutro com enzima), Pika DCE (Rhoto Pharm. Co. peróxido neutro com enzima), e Clean Soft (Kamemizu Chem. Inc. Co. - enzima), por 180 dias. Amostras imersas em água destilada foram usadas como controles. Em seguida, o crescimento fúngico e a formação de biofilme foram estudados. Os resultados sugerem que a colonização fúngica pode ser controlada pela combinação do material com o higienizador de prótese, pois várias combinações exibiram uma alta colonização quando comparada as amostras controles, como por exemplo, para a resina acrílica, amostras imersas nos higienizadores Polident e Pika DCE, exibiram maior formação de biofilme em relação às amostras controles.

Keyf e Güngör ${ }^{48}$ (2003) avaliaram os efeitos deletérios de alvejantes e tabletes de limpeza sobre a superfície de liga Cobalto-Cromo usada na fabricação de próteses parciais removíveis. Amostras da liga foram imersas nas soluções: Corega Tabs (Stafford-Miller Ltd.), alvejante Axion (Colgate Palmolive Co.) e água de torneira, por 30 minutos diários durante 30 dias. As amostras foram analisadas em um espectrofotômetro quanto à reflectância, em microscópio óptico quanto à mudanças na superfície, e também foi verificado o peso das 
amostras. As maiores alterações ocorreram com o uso de alvejante, devido ao efeito corrosivo do hipoclorito de sódio. O tablete efervescente também afetou a reflectância da superfície, porém o efeito corrosivo foi menor do que o alvejante. Os autores concluíram que soluções de limpeza comerciais não deveriam ser indiscriminadamente usadas em próteses com componentes metálicos.

Pavarina et al. ${ }^{82}$ (2003b) analisaram a eficácia de um protocolo para controle de infecção, limpeza e desinfecção de próteses removíveis. Foram selecionados 32 pacientes usuários de próteses totais ou próteses parciais removíveis. Na primeira fase do estudo, foram obtidas culturas das 64 próteses, e após um período de incubação de 24 horas, o meio de cultura foi avaliado para determinação do crescimento microbiano. Para eliminar o material orgânico remanescente nas próteses, cada prótese foi escovada por 1 minuto com clorexidina 4\% e escova de dentes macia, e enxaguadas em água estéril por 1 minuto. As próteses foram então distribuídas em 4 grupos e colocadas por 10 minutos em uma das seguintes soluções de imersão: gluconato de clorexidina $4 \%$, hipoclorito de sódio $1 \%$, solução de Biocide $0,48 \%$ e solução de Amosan 3,78\% (peróxido alcalino). Após os procedimentos de desinfecção, as próteses foram imersas em água estéril por 3 minutos para eliminação de resíduos das soluções desinfetantes, foram realizados esfregaços e as amostras incubadas novamente. A presença de crescimento microbiano foi determinado após 24 horas. Os resultados obtidos nas culturas iniciais revelaram que todas as próteses estavam contaminadas com microrganismos. Comparando com a cultura inicial, todas as soluções de imersão reduziram o crescimento de microrganismos, exceto Biocide, que não foi efetivo. Concluíram que o protocolo analisado é um método viável para prevenir contaminação cruzada.

Barnabé et al. ${ }^{14}$ (2004) avaliaram a eficácia do hipoclorito de sódio 0,05\% quando associado à escovação com sabão de coco, como agente desinfetante na redução de Estomatite Protética, Streptococcus mutans e Candida albicans.Participaram deste estudo 60 pacientes 
usuários de próteses superiores convencionais, que foram divididos em dois grupos: 1) escovação das próteses com sabão de coco seguido pela imersão em uma solução de água filtrada $(200 \mathrm{ml})$ e água destilada $(10 \mathrm{ml})$ (solução placebo) por 10 minutos e 2) escovação das próteses com sabão de coco seguido pela imersão em uma solução de água filtrada (200 $\mathrm{ml})$ e hipoclorito de sódio $1 \%(10 \mathrm{ml})$, resultando em uma solução $0,05 \%$ com $\mathrm{pH}$ 8,5, por 10 minutos. Antes e após 15 dias, foi realizada uma análise clínica em ambos os grupos para verificar as condições da mucosa e verificar a limpeza das próteses. Os pacientes foram instruídos a limpar as próteses uma vez ao dia, e somente 28 pacientes retornaram ( 9 para o primeiro grupo e 19 para o segundo grupo). Testes microbiológicos foram usados para isolar Candida albicans e Streptococcus mutans. Os autores concluíram que a associação do sabão de coco e hipoclorito de sódio $0,05 \%$ reduziu significantemente os sinais clínicos de Estomatite Protética, mas não reduziu Candida albicans. Streptococcus mutans foi reduzido, mas não significantemente. A associação entre sabão de coco e hipoclorito de sódio $0,05 \%$ foi efetiva no controle do biofilme da prótese. Este estudo confirmou a necessidade de recomendação de agentes de limpeza químicos para reduzir a patogenicidade de microrganismos presentes na superfície de próteses totais, resultando em melhora das lesões da Estomatite Protética.

Yilmaz et al. ${ }^{12}$ (2004) avaliaram os efeitos de alguns desinfetantes nas propriedades físicas (sorção de água, solubilidade e dureza) de 4 materiais para forramento de prótese. Amostras preparadas com os materiais: Tempo (Lang Dental), Immediate (Lang Dental), Flexacryl Soft (Lang Dental) e Ufi Gel P (Voco), foram testadas após a aplicação dos desinfetantes: Deconex 5\% (Borer Chemie) e Savlex 3,5\% (Drogsan) por 10 minutos, hipoclorito de sódio $2 \%$ e hipoclorito de sódio 5,25\% por 5 minutos, e comparadas ao grupo controle (água destilada). Concluíram que os desinfetantes afetam as propriedades físicas de sorção de água, solubilidade, e dureza dos materiais para forramento. 
Webb, Thomas e Whittle ${ }^{110}$ (2005), avaliaram a eficácia de 2 métodos de tratamento na estomatite de dentadura. Sessenta pacientes com estomatite foram distribuídos em 3 grupos: imersão da prótese em hipoclorito de sódio (Milton Antibacterial Solution; Proctor and Gamble), desinfecção das próteses em microondas (Sharp) e controle (higienização usual). Os pacientes imergiam suas próteses durante a noite (Solução de Milton 0,02\%) e as próteses eram irradiadas em microondas por 10 minutos, durante uma semana. Foram realizadas fotografias do palato e colheitas microbiológicas provenientes da mucosa palatina e das próteses (superiores e inferiores) antes e após o tratamento. Os resultados mostraram que, tanto a irradiação por microondas, como a imersão em hipoclorito de sódio por uma semana, foram efetivos, reduzindo o número de Candida tanto das próteses, como do palato.

Yilmaz et al. ${ }^{113}$ (2005) avaliaram o efeito de 4 procedimentos desinfetantes de imersão em 4 materiais de forramento resilientes contaminados com Staphylococcus aureus, Streptococcus sobrinus, e Candida albicans. Os materiais de forramento resilientes: Tempo (Lang Dental), Immediate (Lang Dental), Flexacryl Soft (Lang Dental) e Ufi Gel P (Voco) foram contaminados com os microrganismos, e então submetidos à desinfecção nas soluções: Deconex 5\% (Borer Chemie), Savlex 3,5\% (Drogsan), hipoclorito de sódio 2\% e hipoclorito de sódio 5,25\%. As amostras foram imersas por 5 minutos em cada solução, sendo que amostras controles foram imersas em água destilada por 5 minutos. Os resultados mostraram que, para todos os microrganismos, a imersão em hipoclorito de sódio 5,25\% reduziu o número de microrganismos aderentes viáveis, comparado à imersão em hipoclorito de sódio 2\%, que teve uma maior redução que Deconex 5\% e Savlex 3,5\%. Concluíram que a desinfecção dos materiais de forramento com a solução de hipoclorito de sódio $5,25 \%$ foi a técnica de imersão mais efetiva.

Paranhos et al. ${ }^{80}$ (2007) avaliaram os níveis de biofilme nas superfícies internas de próteses totais superiores após o uso de 3 métodos de higiene: escovação, solução de peróxido 
alcalino e combinado. Foram selecionados 36 usuários de próteses totais que foram instruídos a limpar suas próteses de acordo com os seguintes tratamentos: 1) Controle: enxágüe e imersão em água durante a noite; 2) Químico: imersão em solução de peróxido alcalino (Bony Plus - Bonyf AG) por 5 minutos; 3) Mecânico I: escovação 3 vezes ao dia com escova (Johnson and Johnson's Soft toothbrush, Johnson and Johnson Ltd.) e dentifrício especifico para prótese (Dentu Creme- Dentco); 4) Combinado I: associação entre imersão e escovação de acordo com os métodos 2 e 3; 5) Mecânico II: escovação 3 vezes ao dia com escova Oral B (Oral B n 40; Gillette do Brasil Ltd.) e dentifrício especifico para prótese (Dentu CremeDentco); e 6) Combinado II: associação dos métodos 2 e 5 . Os pacientes empregaram todos os métodos de forma cruzada tendo a duração de 7 dias cada método. $\mathrm{O}$ biofilme presente na prótese foi evidenciado (vermelho neutro 1\%), as superfícies internas das próteses foram fotografadas, sendo estas fotos transferidas para um computador e o biofilme quantificado por meio de um software (Image Tool 2.02). Os autores concluíram que o emprego da escovação de forma isolada foi mais efetiva que o método químico empregado. Os melhores resultados foram obtidos pela combinação dos métodos (imersão e escovação).

\subsection{Alteração de cor}

Uma vez que existe correlação entre a higienização da prótese e seu branqueamento, estudos têm sido realizados com o intuito de avaliar o efeito de agentes higienizadores sobre a propriedade de cor de resinas acrílicas. 
Anthony e Gibbons ${ }^{7}$ (1958) avaliaram métodos utilizados para limpeza das próteses e estudaram o desenvolvimento de um método simples para higienização. Foram aplicados 120 questionários, onde $41 \%$ do grupo estudado usavam higienizadores de prótese comerciais, $11 \%$ usavam higienizadores caseiros como vinagre, Clorox, soda, sal, sabão, higienizadores abrasivos ou Listerine. Apenas 5\% utilizavam a imersão como único método de higienização de prótese. Os autores mostraram a influência dos higienizadores caseiros nas bases das próteses, assim como os efeitos de exposições prolongadas por 3 semanas aos higienizadores comerciais. As amostras foram suspensas e metade de cada amostra foi imersa na solução de limpeza. Para avaliar a estabilidade de cor, uma a cada duas amostras expostas aos higienizadores, foi irradiada por 24 horas por uma lâmpada ultravioleta. Avaliando a alteração de cor visualmente, concluíram que os higienizadores comerciais e caseiros (Clorox, bicarbonato de sódio, amônia, vinagre e sal) são inofensivos aos materiais plásticos das próteses e que substâncias que contêm álcool ou óleos essenciais não podem ser recomendadas como higienizadores de próteses. Foram observadas ranhuras na resina causadas por agentes abrasivos e também concluíram que uma solução contendo 1 colher de chá de Clorox e 2 colheres de chá de Calgon em metade de um copo de água consiste em agente higienizador eficaz e seguro para imersões noturnas ocasionais.

Bates e Smith $^{16}$ (1965) realizaram testes laboratoriais e clínicos de materiais de forramento. No teste laboratorial foram confeccionadas amostras com os materiais: Palasiv (Kulzer \& Co.), Neo-plastupalat (Farben fabriken Bayer A.G.), Coesoft (Coe Laboratories), Cora-line (Coralite Dental Products), Durabase (Reliance Dental Mfg. Co.), Flexene (Cosmos Dental Products), Soft Oryl (The William Getz Corp.), Molloplast B (Kostner \& Co.), Flexibase (Flexico Developments Ltd.), D.P.Silyne (Dental Perfection Co.), Verone R.S (Davis) e Corvic/DOP 70\% (Dental Mfg. Co.). Foram avaliadas as propriedades de absorção de água, absorção de óleo, estabilidade de cor, força adesiva, dureza, elasticidade e rigidez. 
Os efeitos de higienizadores na cor e na superfície foram analisados visualmente. Os higienizadores (ácido mineral diluído, peróxidos e hipocloritos) foram usados de acordo com as instruções dos fabricantes por 6 semanas. O tipo oxigenado causou bolhas na superfície dos materiais termopolimerizáveis e autopolimerizáveis quando usados a $60^{\circ} \mathrm{C}$. O higienizador hipoclorito causou branqueamento de todos os materiais, com exceção do Corvic/DOP 70\%. Os dados sugerem que nenhum dos higienizadores utilizados é adequado para os materiais resilientes testados. Clinicamente, dois dos materiais de forramento foram aplicados nas bases das próteses de 89 pacientes para avaliação do conforto, irritação da mucosa, gosto e os efeitos do uso. Ambos os materiais foram clinicamente satisfatórios.

Pazzini, Mutti e Pazzini ${ }^{83}$ (1972) testaram a eficácia de três higienizadores e propriedades adversas, como a descoloração e a deformação, de resinas acrílicas autopolimerizáveis e termopolimerizáveis. Os higienizadores testados foram: A) Steradent (Ind. E Com. Atlants Brasil Ltda.), pó alcalino dissolvido em água morna, imersão da prótese por 20 minutos, ou a noite toda; B) Pó Hamilton (Profar Ltda.), pó alcalino dissolvido em água, imersão da prótese por 3 horas ou mais e C) Alvor (Profc S.A.), ácido, prótese limpa com algodão embebido no líquido. Para o teste de descoloração, corpos-de-prova de ambas as resinas foram submetidos às soluções higienizadoras por 30 vezes e, em seguida, foi aplicado o teste de estabilidade de cor, onde os corpos-de-prova submetidos à higienização eram comparados com corpos-de-prova mantidos em água. Os resultados mostraram que as soluções não foram eficazes na remoção dos depósitos de cálculos, porém relativamente eficazes na remoção de pigmentação; não afetaram as estruturas das resinas, e não causaram distorções das bases das próteses. Os corpos-de-prova em resina acrílica autopolimerizável descoloriram, mas não foi possível atribuir esse efeito aos higienizadores, pois corpos-de-prova armazenados em água também descoloriram. Concluíram que os higienizadores podem ser recomendados aos pacientes como um método auxiliar na manutenção da higiene de próteses. 
Purnaveja et al. ${ }^{87}$ (1982) avaliaram a estabilidade de cor de dois materiais autopolimerizáveis para base de prótese (De Trey’s SOS e Kulzer’s Palapress) submetidos a higienizadores (Denclen - ácido clorídrico; Steradent-perborato) e água destilada (controle). As soluções eram trocadas a cada 8 horas durante 14 dias de imersão. A leitura de cor de cada amostra foi realizada antes e após a imersão em higienizadores com um colorímetro (Tintometer). Concluíram que as resinas acrílicas autopolimerizáveis tendem a mudar de cor quando imersas em higienizadores de prótese e água.

Goll, Smith e Plein ${ }^{39}$ (1983) avaliaram os efeitos de higienizadores de prótese em materiais de forramento. Amostras de 8 materiais de forramento: Coe-Confort (Coe Laboratories), F.I.T.T. (Sybron/Kerr Ritter), Hydro-Cast (Kay-See Denatl Mfg. Co.), Lynal (L.D. Caulk Co.), Softone (Harry J. Bosworth Co.), Tissuedyne (Professional Products Co.), Veltec (Teledyne Dental Products) e Visco-gel (Amalgamated Dental - De Trey); foram imersas em 11 soluções: Clorox-Calgon (The Clorox Co./Beecham Products), Denalan (Whitehall Laboratories), Duo (Block Drug Co.), Efferdent (Warner-Lambert Co.), Kleenite (Richardson-Merril), Mersene (Colgate-Palmolive Co.), Miller (Bell Dental Laboratory), Polident powder (Block Drug Co.), Polident tablets (Block Drug Co.), água fria $-18,3^{\circ} \mathrm{C}$ e água quente $-54,5^{\circ} \mathrm{C}$ ). As soluções higienizadoras foram trocadas diariamente pelo período de um mês, que correspondeu a 3 meses de imersões durante a noite. Foram verificadas 6 propriedades: mudança de cor, porosidade, distorção superficial, mudança de tamanho, sorção de água e solubilidade. Para avaliar a alteração de cor, amostras imersas em soluções higienizadoras foram comparadas visualmente com amostras controles. Os materiais menos afetados pelos higienizadores foram: Lynal, Tissuedyne, F.I.T.T., e Hydro-Cast. Os materiais mais afetados pelos higienizadores foram: Viscogel, Softone e Veltec. Os materiais de coloração branca (F.I.T.T., Softone, Hydro-Cast, Coe-comfort) e os materiais claros (Viscogel e Lynal) mostraram estabilidade de cor após 30 dias de imersão. Os materiais coloridos 
(Veltec e Tissuedyne) apresentaram mudanças de cor. Amostras de Veltec imersas nos 9 higienizadores descoloriram. A solução de Clorox-Calgon clareou as amostras de materiais brancos. Soluções de Clorox-Calgon e Miller demonstraram o mesmo desempenho, sendo compatível com muitos materiais. Mersene e Duo ficaram em segundo e terceiro lugares, respectivamente. A espessura dos materiais influenciou nos efeitos dos higienizadores nas propriedades avaliadas.

Robinson, McCabe e Storer $^{90}$ (1985) investigaram o branqueamento da resina acrílica por meio de estudos da microestrutura de próteses branqueadas e por testes laboratoriais, onde resinas termopolimerizáveis (Metocryl e SR 3/60) e autopolimerizável (De Trey Rapid Repair) foram expostas a higienizador de prótese à base de peróxido alcalino (Steradent), e então submetidas à transmissão de luz. Uma das resinas termopolimerizáveis (Ivoclar) foi submetida ao teste mecânico de flexão. Nenhuma das resinas exibiu o branqueamento observável nas amostras clínicas, e não ocorreu mudança nas propriedades mecânicas. Concluíram que próteses severamente branqueadas mostram claras evidências de serem atacadas por agentes externos. $\mathrm{O}$ tratamento em materiais termopolimerizados equivalente a 1 ano de tratamento diário com peróxido alcalino não causou branqueamento significante, nem afetou as propriedades mecânicas da resina termopolimerizável Metocryl.

Publicações têm ressaltado a importância da temperatura da água no efeito do branqueamento da resina acrílica, e testes têm sido realizados em temperaturas superiores aquelas recomendadas pelos fabricantes de produtos de higienização de prótese.

Crawford et al. $^{30}$ (1986) simularam os procedimentos de higienização usados por pacientes com próteses branqueadas, por meio de testes laboratoriais. Foram observadas as influências dos higienizadores sobre as propriedades físicas da resina acrílica, por meio da análise da aparência visual, características superficiais, transmissão de luz e resistência à flexão. Foram simulados procedimentos diários de 100 dias (imersões de 30 minutos e 
durante a noite). Os resultados mostraram que amostras submetidas à água muito quente $\left(100^{\circ} \mathrm{C}\right)$, com ou sem higienizador de prótese (Steradent Denture Cleaning Tablets, Reckitt Dental Care Products), mostraram uma aparência branqueada. Concluiu-se que, seguindo as instruções dos fabricantes, ou seja, uso do higienizador Steradent em $150 \mathrm{ml}$ de água a $50^{\circ} \mathrm{C}$, não ocorrem efeitos significantes nas propriedades físicas das resinas. Concluíram que o branqueamento é um efeito de opacificação da superfície produzido pelo uso de água fervente.

Crawford, Newton e Yemm ${ }^{29}$ (1987) avaliaram os materiais e métodos de higiene de pacientes com próteses branqueadas, e pacientes usuários de próteses selecionados aleatoriamente. As próteses foram classificadas em aquelas exibindo cor normal e com perda de cor. Foram realizados testes para determinar se o clareamento da resina acrílica foi um fenômeno puramente superficial ou se envolvia a espessura total da prótese. Cortes transversais das próteses branqueadas e normais foram analisados em microscópio eletrônico de varredura. As amostras de próteses branqueadas demonstraram dois fatores em comum: uso de um agente para limpeza da prótese (peróxido alcalino ou alvejante doméstico) e uso de água muito quente. $\mathrm{O}$ exame dos cortes transversais das próteses branqueadas indicou penetração do processo de branqueamento. Quando examinadas em microscópio eletrônico de varredura, as superfícies das próteses branqueadas mostraram uma deterioração, com danos da camada superficial, dando uma aparência rugosa às superfícies.

Robinson, McCabe e Storer $^{89}$ (1987) realizaram uma série de testes para avaliar resinas acrílicas (termopolimerizáveis e autopolimerizável) submetidas a tratamentos higienizadores, incluindo, além do tratamento com higienizador de prótese, a exposição em altas temperaturas $\left(95^{\circ} \mathrm{C}\right)$ e a vapor de solvente (acetona). Os higienizadores utilizados nos testes foram: peróxido alcalino (Steradent - Reckitt Household Toiletry Products) e hipoclorito doméstico (Domestos - Lever Bros. Ltd.). Concluiu-se que ambos os materiais foram branqueados pelas 
soluções em altas temperaturas (hipoclorito, água e peróxido alcalino). A exposição a vapor de solvente antes da imersão em algumas das soluções aumentou o efeito de branqueamento. Amostras branqueadas sofreram redução da resistência a flexão.

Arab, Newton e Lloyd $^{10}$ (1988), realizaram testes laboratoriais em resina acrílica, utilizando um higienizador de prótese (Steradent) a $50^{\circ} \mathrm{C}$ (temperatura recomendada pelo fabricante), e em temperaturas elevadas $\left(60^{\circ} \mathrm{C}, 70^{\circ} \mathrm{C}, 80^{\circ} \mathrm{C}, 90^{\circ} \mathrm{C}\right.$ e $\left.100^{\circ} \mathrm{C}\right)$. Foram realizadas imersões em água a estas mesmas temperaturas sem a presença do agente higienizador. Corpos-de-prova controles foram armazenados em água a temperatura ambiente sem nenhum tipo de procedimento de higienização. Foram realizadas imersões de 30 minutos diários, realizados por 100 dias. Um branqueamento foi observado nas amostras submetidas a temperaturas de $90^{\circ} \mathrm{C}$ e $100^{\circ} \mathrm{C}$, e em uma menor extensão em $80^{\circ} \mathrm{C}$, independente da presença do higienizador. Também ocorreram mudanças nas propriedades físicas.

Arab, Newton e Lloyd $^{9}$ (1989) realizaram testes laboratoriais que simularam os procedimentos de higienização dos pacientes com próteses branqueadas, em amostras de resina acrílica com alto e baixo nível de monômero residual. Foram utilizadas as soluções: 1) Steradent (dissolvido em $150 \mathrm{ml}$ de água a $50^{\circ} \mathrm{C}$ como recomendado pelo fabricante); 2) água $\left.\left(50^{\circ} \mathrm{C}\right) ; 3\right)$ água fervente $\left(100^{\circ} \mathrm{C}\right)$ com o higienizador e 4) água fervente. Amostras controles foram armazenadas em água a temperatura ambiente $\left(18^{\circ} \mathrm{C}\right)$ sem nenhum tipo de procedimento de higienização. Foram realizadas imersões de 30 minutos diários, realizados por 100 dias. Utilizou-se um espectrofotômetro para quantificar a transmissão de luz através da amostra. Concluiu-se que um elevado nível de monômero residual não é o principal fator do branqueamento do acrílico das próteses, mas $\operatorname{sim}$ a alta temperatura da água, independentemente da presença do higienizador.

McNeme, Von Gontem e Woolsey ${ }^{67}$ (1991), determinaram os efeitos de agentes desinfetantes químicos em resinas acrílicas fotoativada (Triad VLC - Dentsply), termoativada 
(CH Lucitone - Dentsply) e autopolimerizável (Truliner - Harry J. Bosworth Co.). Os desinfetantes testados foram: Hipoclorito de sódio 1\% (Clorox Corp.), Exspor (Alcide Corp.), Cidex 2\% (Johnson \& Johnson) e Wescodyne-D (West Chemical Products). As mudanças de cor foram avaliadas em intervalos de tempo (15 minutos, 30 minutos, 45 minutos, 60 minutos, 2 horas, 4 horas, 8 horas, 16 horas, 24 horas, 48 horas e 72 horas). Uma única amostra da resina $\mathrm{CH}$ Lucitone foi imersa em hipoclorito de sódio 5,25\% por 72 horas. As amostras foram classificadas pelos níveis de descoloração numa escala de pouco, moderado e severo. Nenhuma mudança de cor observável foi vista antes de 2 horas de imersão. Os agentes hipoclorito de sódio a 1\% e Cidex 2\% produziram uma mínima descoloração das resinas acrílicas, e o Wescodyne-D produziu a maior descoloração. A resina $\mathrm{CH}$ Lucitone foi a que apresentou a menor mudança de cor, seguida pela Triad VLC e Truliner. Concluíram que, se os tempos de desinfecção recomendados pelos fabricantes forem seguidos, não ocorrerá mudança de cor das próteses.

Buyukilmaz e Ruyter ${ }^{23}$ (1994) avaliaram quantitativamente a descoloração de materiais para base de prótese (um fotopolimerizável, três termopolimerizáveis e três autopolimerizáveis) após a exposição a chá, café, água destilada $\left(50^{\circ} \mathrm{C}\right)$ sem exposição à luz, e água e luz solar artificial. As amostras permaneceram imersas em chá e café por 96 horas a $50^{\circ} \mathrm{C} \pm 1{ }^{\circ} \mathrm{C}$, e em seguida foram limpas por: 1)lavagem com sabão; 2) escovação com sabão e 3) escovação com pasta de dentes. Amostras manchadas e limpas foram armazenadas em soluções de café e chá por mais 1000 horas a $50^{\circ} \mathrm{C} \pm 1^{\circ} \mathrm{C}$. Em seguida, as amostras foram limpas e ambos os lados das amostras foram desgastados. Três amostras de cada material foram colocadas em água destilada por 1440 horas a $50^{\circ} \mathrm{C} \pm 1^{\circ} \mathrm{C}$. Três amostras de cada material foram usadas para estudar mudanças na aparência após 540 horas de exposição à luz solar artificial e água a $37^{\circ} \mathrm{C} \pm 5^{\circ} \mathrm{C}$. Medidas de cor foram feitas usando espectrofotometria de reflectância (sistema CIELab) antes e depois das amostras terem sido expostas às soluções de manchamento, água (com e sem luz artificial), após a limpeza das amostras, e após o desgaste. 
Concluíram que café e chá mancharam o material superficialmente, e que a escovação com pasta de dente e o desgaste das superfícies das amostras reduziu a descoloração para um nível aceitável. Todos os materiais foram relativamente estáveis quanto à descoloração durante as imersões por longos períodos em água destilada a $50^{\circ} \mathrm{C} \pm 1{ }^{\circ} \mathrm{C}$. Quando expostos à luz solar artificial e água, os materiais comportaram-se diferentemente quanto à estabilidade de cor.

Liberman et al. ${ }^{57}$ (1995) estudaram as condições laboratoriais mais favoráveis para experimentos de avaliação de mudança de cor de resinas acrílicas. Discos de polimetilmetacrilato foram preparados de dez polímeros para base de prótese (Fastcure - pink, Fastcure - clear, Meadway, Minacryl, QC-20, SR Ivocap, SR 3/60, Trevalon, Trevalon C, Trevalon HI). Três destas resinas (SR Ivocap, Minacryl e Fastcure) foram selecionadas para determinação apropriada da cor do plano de fundo para a realização de medidas quantitativas de mudanças de cor. Nove planos de fundo foram utilizados e foi determinado o uso do plano de fundo branco. Metade de cada amostra foi exposta por 24 horas a uma lâmpada simuladora de luz solar. A cor das amostras foi medida no sistema CIE L*a*b* usando um colorímetro fotoelétrico (Minolta CR-221 Chroma Meter). As medidas foram realizadas contra o plano de fundo branco. Mudanças significantes nos valores de $b^{*}$ e $E^{*}$ foram observados após a exposição de luz. Os dados objetivos foram comparados com os resultados de avaliações subjetivas e foi demonstrado que uma mudança em $b^{*}$ de 1,5 unidades foi perceptível subjetivamente pelo olho humano em $100 \%$ dos casos.

Ünlü, Altay e Sahmali ${ }^{105}$ (1996) analisaram o efeito de higienizadores químicos em resinas acrílicas termopolimerizáveis e autopolimerizáveis. Foram selecionadas 3 resinas acrílicas termopolimerizáveis (Rodex - Rodex, QC-20 - De Trey e Meliodent heat - Bayer) e 3 autopolimerizáveis (Meliodent auto - Bayer, Acralite - Acralite e Orthodontic - Dentarium). Foram utilizados 4 higienizadores químicos: Polident (Block Drug), Efferdent (WarnerLambert), Blend-A-Dent (Wick Pharma) e Corega (Stafford-Miller Limited Hatfield). As 
amostras foram imersas por 240 horas, sendo que as soluções foram trocadas a cada 8 horas, simulando 30 noites de imersão.Um reflectômetro foi utilizado para medir os valores de cor das amostras. O higienizador Corega provocou o maior efeito de branqueamento nas resinas, sendo que o Polident causou o menor branqueamento. A resina acrílica termopolimerizável QC-20 apresentou um branqueamento mínimo, enquanto a maior mudança foi vista com as resinas acrílicas autopolimerizáveis.

May et al. ${ }^{64}$ (1996) determinaram a estabilidade de cor após envelhecimento acelerado em 5 materiais para base de prótese termopolimerizáveis convencionais, 2 materiais de termopolimerização rápida e um material de microondas (Lucitone, Hy-pro-Dentsply International; Accelar 20 Adv. Form.-Modern Materials; Lucitone 199-Dentsply International; Ebony light-Hygenic Corp.; Lucitone, CH-Dentsply International; Lucitone, TruTone-Dentsply International; Acron-G-C Dental Industrial Corp.) processados por energia de microondas (5 minutos a alta temperatura). A mudança de cor $(\Delta \mathrm{E})$ foi medida com um instrumento Chroma Meter II, antes e após o envelhecimento acelerado de 300, 600 e 900 horas. Todos os materiais polimerizados em microondas exibiram mudanças de cor.

Polyzois et al. ${ }^{85}$ (1997) avaliaram os efeitos de soluções desinfetantes na cor de resinas acrílicas (termopolimerizável, fotoativada e autopolimerizável). Foram utilizados 4 desinfetantes (Klinex - hipoclorito de sódio diluído 1:10 com água destilada - 0,525\%; Cidex 7 - glutaraldeído alcalino 2\%; Hibitane - Clorexidina 5\% diluída 1:10 em água destilada 0,5\%; e Cabadol - fenol) e 3 resinas (Paladon 65 - termopolimerizável; Triad - fotoativada; e ProBase Cold - autopolimerizável). As amostras foram imersas nos desinfetantes por 10 minutos, 10 horas e 7 dias. Amostras adicionais de cada resina testada foram colocadas em água destilada como controle. Medidas de cor foram feitas antes das imersões e nos intervalos de tempo utilizando-se um colorímetro. As resinas ProBase Cold e Triad mostraram os maiores valores de alteração de cor quando imersas no desinfetante Cabadol após 7 dias. A 
resina termopolimerizável (Paladon 65) mostrou a melhor estabilidade de cor após imersão nos desinfetantes testados. Concluíram que, se os tempos de desinfecção recomendados forem seguidos, não ocorrerão mudanças de cor visíveis nas resinas acrílicas.

Ma, Johnson e Gordon ${ }^{58}$ (1997) avaliaram a ação de desinfetantes químicos sobre a textura superficial e a cor de resinas acrílicas. Cinco soluções desinfetantes (Clorox - Clorox; Banicide - Pascal Comp. Inc.; Cidex-7 - Surgikos; Biocide - Biotrol International; Multicide - Biotrol International) em resinas autopolimerizáveis (Dentsplay reline material - Dentsply; Hygenic HyFlo - The Hygenic Corp.; Hygenic Perm - The Hygenic Corp), termopolimerizável (Lucitone 199 - Dentsply) e fotopolimerizável (Triad VLC reline resin Dentsply) foram analisados em quatro tempos de imersão (10 minutos, 30 minutos, 24 horas e 7 dias). Foi utilizado um colorímetro para análise da cor. Diferenças estatísticas foram demonstradas entre desinfetantes e resinas tanto para cor, como para textura superficial; porém, essa mudança foi clinicamente insignificante. O desinfetante Multicide (Fenólico) não deve ser usado nas resinas estudadas, devido aos danos superficiais causados em todas as resinas após 30 minutos de imersão. Quando comparado com outros desinfetantes, o Biocide (desinfetante a base de iodo) foi o que demonstrou mudança de cor significante nas resinas acrílicas, exceto para Lucitone 199. Com o uso do desinfetante Biocide todas as resinas tornaram-se mais escuras. Somente a Lucitone 199 não exibiu mudança de cor após 7 dias de imersão. A imersão no desinfetante Clorox (hipoclorito de sódio a 5,25\%) por 7 dias deixou as resinas mais claras, exceto para Triad VCL (fotopolimerizável).

Tan et al. ${ }^{102}$ (2000) comparam cor, textura e dureza do material de forramento de prótese resiliente Molloplast B com superfícies sem acabamento, polidas e ásperas, após tratamento com higienizadores de prótese contendo hipoclorito, persulfato, ou perborato $\left(25^{\circ} \mathrm{C}\right.$ ou $\left.55^{\circ} \mathrm{C}\right)$ e soluções controles em água de torneira a temperaturas de $25^{\circ} \mathrm{C}$ e $55^{\circ} \mathrm{C}$. As soluções de imersão foram: Efferdent (Warner'Lambert Co.- contém perborato), Polident 
(Block Drug Co. - contém perborato), Kleenite (Regent Labs Inc. - contem perborato), Sparkle-Dent (U.S. Dental Corp. - contem persulfato) e Javex/Calgon ( Colgate Palmolive Canadá Inc. e Beecham Canadá Inc.). As amostras foram imersas por $4 \frac{1}{2}$ meses, sendo as soluções substituídas duas vezes por dia. Para o grupo Sparkle-Dent, as amostras foram imersas por 15 minutos de acordo com as instruções do fabricante. Antes e após as imersões (4 $1 / 2$ meses) foram avaliadas a cor, textura e dureza das superfícies das amostras. Um densitômetro de cor foi usado para analisar a luz refletida da superfície do material de forramento. Os resultados mostraram que amostras com superfícies rugosas após o tratamento com higienizador contendo perborato apresentaram maior perda de cor quando comparadas ao controle. Também ocorreu um aumento da dureza quando utilizados alguns higienizadores contendo perborato, comparado com o higienizador contendo hipoclorito após o tratamento a $25^{\circ} \mathrm{C}$. Nenhuma diferença foi observada na textura superficial.

Jin et al. ${ }^{45}$ (2003) analisaram as mudanças de rugosidade superficial e estabilidade de cor após 180 dias de uso de 5 higienizadores de prótese em 7 materiais: dois forradores acrílico autopolimerizante (Soften - Kamemizu Chem. Ind. Co.; Nissin Soft Reverse - Nissin Dental Products Inc.), quatro forradores de silicone autopolimerizáveis (Mollosil - Detax Karl Huber GmbH є Co. KG; Evatouch - Neo Dental Chemical Products Co.; Tokuyama Soft Relining Tokuyama Corp.; GC Denture Relining - GC Dental Industrial Corp.), um forrador silicone termopolimerizável (Molloplast B - Detax Karl Huber GmbH є Co. KG), e uma resina acrílica termopolimerizável (Bio resin - Shofu Inc.). Foram utilizados os higienizadores: Steradent (Reckitt $\varepsilon$ Colman - peróxido alcalino), Correct (Shionogi Chem. Co. - peróxido neutro com enzima), Polident (Kobayashi Block Co. - peróxido neutro com enzima), Pika DCE (Rhoto Pharm. Co. - peróxido neutro com enzima), e Clean Soft (Kamemizu Chem. Inc. Co. - enzima). Três amostras de cada material foram imersas na solução de cada higienizador por 8 horas a temperatura ambiente, e imersas em água destilada por 24 horas a $37^{\circ} \mathrm{C}$. Água destilada foi 
usada como solução controle. A rugosidade superficial de cada amostra foi medida após 1, 3, 7, 14, 28, 60, 90 e 180 dias de imersão. As mudanças de cor de cada material foram medidas com um colorímetro (Chroma Meter 34, CR, 321) e calculadas de acordo com o sistema CIELAB. O material Evatouch exibiu severas mudanças na rugosidade superficial pelos higienizadores, e o material GC Denture Relining mostrou as menores mudanças. Alterações severas de cor também foram observadas. Com exceção do Evatouth, os quatro materiais de forramento de silicone foram mais estáveis na rugosidade superficial e na mudança de cor, quando comparados com os dois materiais de forramento acrílicos. Um material silicone autopolimerizável (GC denture relining) e um silicone termopolimerizável (Molloplast B) demonstraram a melhor estabilidade após 180 dias.

Sato et al. $^{93}$ (2005), avaliaram a resistência à flexão e alteração de cor de resinas acrílicas termopolimerizáveis (Lucitone 550 - Dentsply; QC-20 - Dentsply; Triplex - Ivoclar) após imersão em soluções higienizadoras de próteses totais (Bony Plus Express - Bonyf AG; Corega Tabs - Block Drug Company; Efferdent Plus - Pfizer Inc.) por 15 minutos e 8 horas, simulando 30 dias de uso. $\mathrm{O}$ teste de resistência à flexão foi realizado em máquina de ensaios universais. Alterações de cor foram avaliadas por meio de fotografias tiradas dos corpos-deprova. A inspeção visual não detectou qualquer alteração de cor. Concluíram que os higienizadores, quando usados de acordo com as instruções dos fabricantes, não afetaram a resistência à flexão, nem causaram alterações de cor nas resinas acrílicas.

Devlin e Kaushik ${ }^{33}$ (2005), determinaram se o tratamento de resinas acrílicas com água quente estava associado com uma redução na dureza superficial e branqueamento da superfície. Amostras da resina acrílica Hy-Pro Lucitone (Dentsply) foram imersas no peróxido alcalino Efferdent (Pfizer Consumer Health Care). Dez amostras foram imersas em água aquecida $\left(40^{\circ} \mathrm{C}\right)$ com um tablete de peróxido alcalino (Efferdent-grupo controle) e dez amostras foram imersas em água fervente $\left(100^{\circ} \mathrm{C}\right)$ com peróxido alcalino (grupo experimental). Foram realizados 30 ciclos de 
24 horas. Um efeito causado pela água quente foi o severo branqueamento de todas as amostras, enquanto que aquelas tratadas com água aquecida não foram afetadas. As amostras tratadas em água quente também absorveram mais água. O tratamento com peróxido alcalino e água resultou em uma significante redução na dureza das amostras, o que não ocorreu com as amostras em água aquecida. Concluíram que a solução quente de peróxido alcalino causou uma supersaturação da superfície acrílica, que resultou no branqueamento, e este branqueamento não foi reversível quando as amostras foram secas.

Malheiros-Segundo ${ }^{60}$ (2007) avaliou propriedades físicas (sorção de água, solubilidade, dureza e alteração de cor) de materiais reembasadores para prótese (Kooliner - GC América Inc.; Elite Soft - Kettenbach) após imersão em pastilha efervescente (Corega Tabs- Block Drug Company) por 5 minutos diários. A sorção e solubilidade foram avaliadas após 120 dias de imersão. A alteração de cor foi avaliada após 30 e 120 dias, com o auxílio de um espectrocolorímetro (BYK-Gardner). A dureza foi avaliada no início, após 30 e 60 dias de imersão. Em todos os testes foram confeccionados grupos controles (imersão em saliva artificial a $37^{\circ} \mathrm{C}$ ). Concluiu-se que o perborato de sódio não influenciou de forma significante nas propriedades avaliadas, sendo que o material Kooliner apresentou maior estabilidade. $\mathrm{O}$ tempo interferiu em todas as propriedades testadas.

Pela revisão da literatura efetuada, observa-se que a eficácia de higienizadores de prótese tem sido estudada, porém a literatura é escassa em relação ao efeito do uso diário de higienizadores químicos para imersão de próteses totais por longos períodos de tempo, e seus efeitos sobre as propriedades das resinas acrílicas termopolimerizáveis. Com base nessas observações, procurou-se estudar o efeito de higienizadores químicos de prótese total durante um período de seis meses de imersão. 
3 Proposição 
O objetivo deste estudo foi avaliar a alteração de cor de resinas acrílicas (convencional e para microondas) após imersão em soluções de hipoclorito de sódio ( $0,5 \%$ e $1 \%)$ e em pastilhas efervescentes à base de peróxido alcalino. 
4 Material e Método 


\subsection{Matriz empregada}

Para a obtenção dos corpos-de-prova, a partir de uma placa de teflon (Riberval Ind. e Com. de Produtos Industriais Ltda, Ribeirão Preto-SP, Brasil) foi obtida uma matriz (Seção de Oficinas de Precisão-Mecânica-USP, Ribeirão Preto-SP, Brasil) contendo 05 orifícios de $15 \mathrm{~mm}$ de diâmetro e $4 \mathrm{~mm}$ de espessura (Fig. 1).

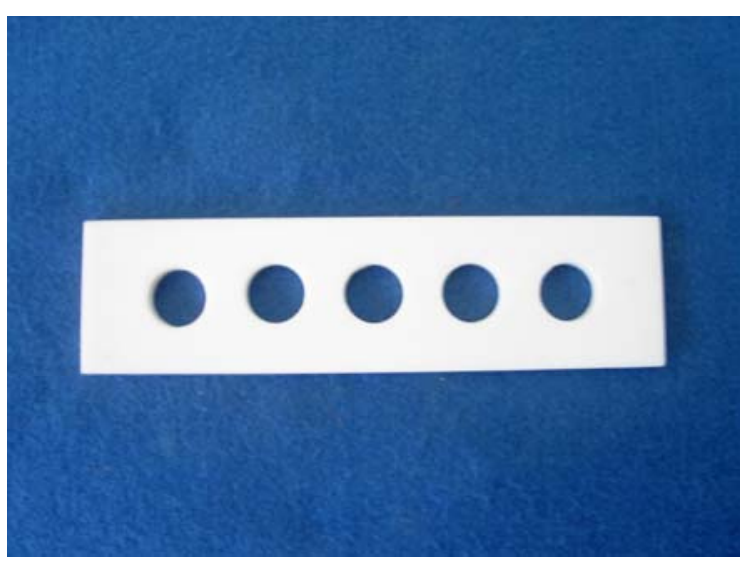

Figura 1: Matriz obtida. 


\subsection{Enceramento, inclusão e obtenção dos corpos-de-prova}

A partir da matriz de teflon pré-fabricada, foram encerados padrões em cera número 9 (Wilson - Polidental Industria e Comércio Ltda., Cotia-SP, Brasil), de 15mm de diâmetro e 4mm de espessura (Fig. 2).

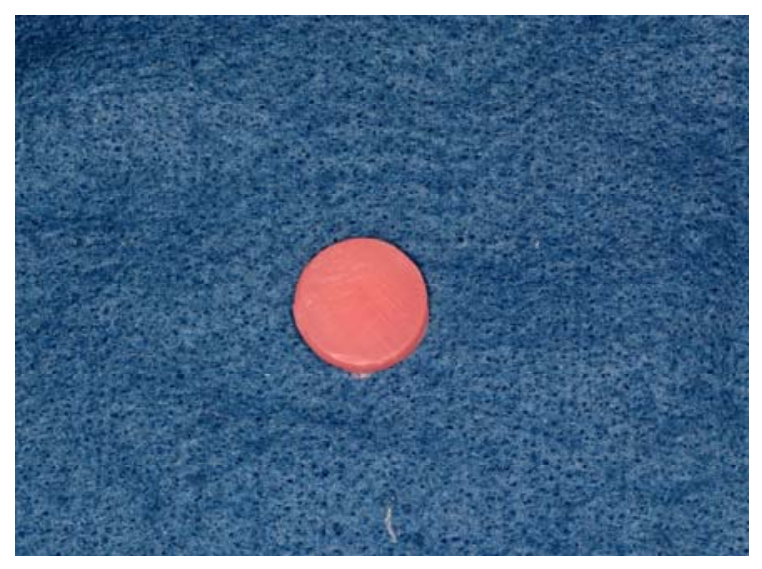

Figura 2: Padrões em cera obtidos.

Os padrões de cera foram incluídos em muflas convencionais (MAC - Artigos Odontológicos e Prótese Ltda., São Paulo-SP, Brasil) e para microondas (Vipi Indústria, Comércio, Exportação e Importação de Produtos Odontológicos Ltda., Pirassununga-SP, Brasil) (Fig. 3), utilizando gesso pedra tipo III (Gesso-Rio-Orlando Antônio Bussioli-ME, Rio Claro-SP, Brasil) e IV (Durone IV- Dentsply Indústria e Comércio Ltda., Petrópoles-RJ, 
Brasil) sob vibração (vibrador odontológico VH Softline - VH Midas Dental Products Ltda., Araraquara-SP, Brasil) (Fig. 4).

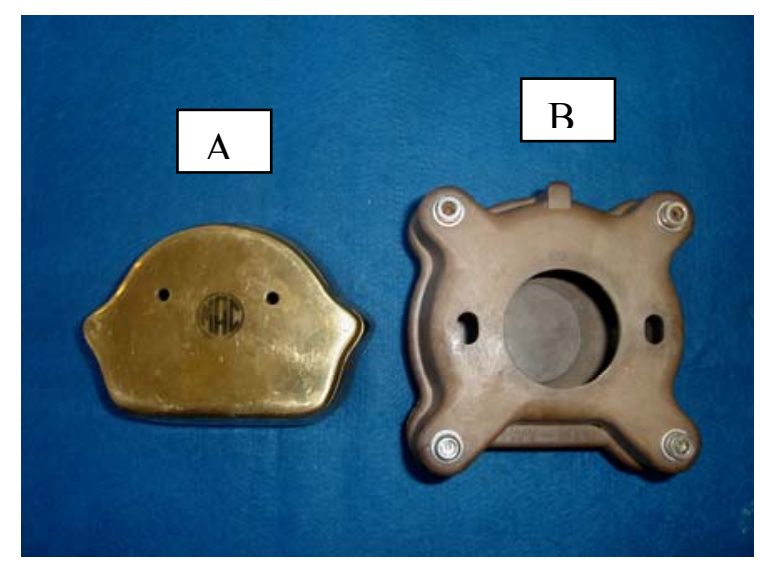

Figura 3: Muflas empregadas: A: convencional; B: microondas.

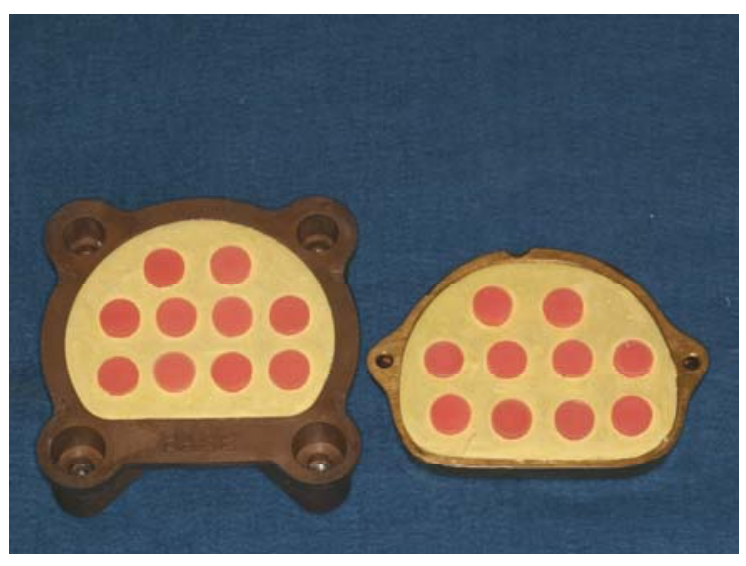

Figura 4: Inclusão dos padrões de cera em muflas (microondas e convencional).

Após a eliminação da cera, as matrizes obtidas em gesso (Fig. 5) foram isoladas (Isolante para Gesso - Cel-Lac - SS White Artigos Dentários, Rio de Janeiro, Brasil), e as resinas acrílicas termopolimerizáveis selecionadas (tabela 1) foram manipuladas, prensadas (prensa hidráulica Protecni-Protecni equip. méd., Araraquara-SP, Brasil) e polimerizadas, segundo as instruções dos fabricantes (Quadro 1). 


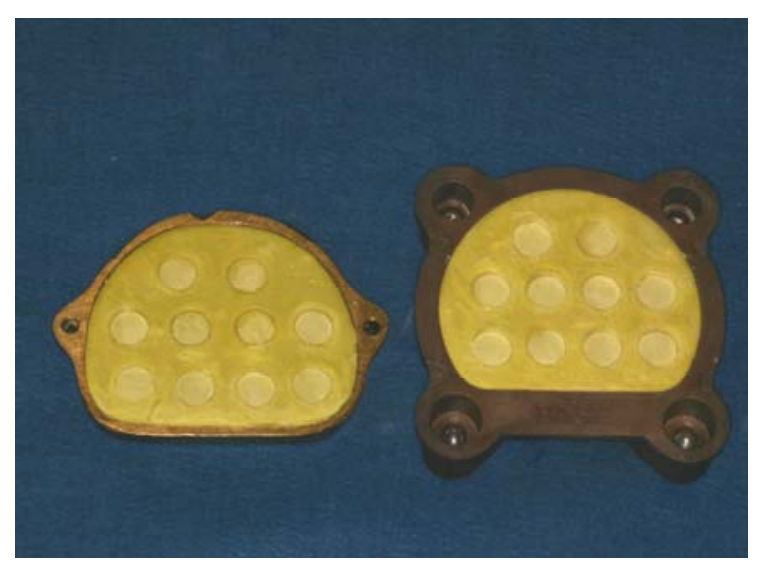

Figura 5: Matrizes obtidas em gesso.

Tabela 1: Resinas acrílicas termopolimerizáveis empregadas.

\begin{tabular}{|c|c|c|c|c|c|}
\hline Marca & Tipo de resina & Fabricante & Lote & Cidade-Estado & País \\
\hline $\begin{array}{c}\text { Lucitone 550 } \\
\text { Rosa médio c/ } \\
\text { veias } \\
\text { (pó + líquido) }\end{array}$ & $\begin{array}{l}\text { Polimerização } \\
\text { por água } \\
\text { quente }\end{array}$ & $\begin{array}{c}\text { Dentsply } \\
\text { Indústria e } \\
\text { Comércio Ltda. }\end{array}$ & \begin{tabular}{|c|} 
Pó: \\
186476 \\
Liquido: \\
200853 \\
\end{tabular} & Petrópolis - RJ & Brasil \\
\hline $\begin{array}{c}\text { Onda Cryl } \\
\text { Rosa c/ veias } \\
\text { (pó + líquido) }\end{array}$ & $\begin{array}{l}\text { Polimerização } \\
\text { por } \\
\text { microondas }\end{array}$ & $\begin{array}{c}\text { Artigos } \\
\text { Odontológicos } \\
\text { Clássico Ltda }\end{array}$ & $\begin{array}{c}\text { Pó: } \\
71505.0 \\
\text { Líquido: } \\
061005\end{array}$ & São Paulo - SP & Brasil \\
\hline
\end{tabular}

Quadro 1. Ciclos de polimerização das resinas acrílicas termopolimerizáveis empregadas.

\begin{tabular}{|c|c|l|c|c|}
\hline $\begin{array}{c}\text { Marca } \\
\text { Comercial }\end{array}$ & $\begin{array}{c}\text { Proporção } \\
\text { Pó/Líquido }\end{array}$ & Prensagem & $\begin{array}{c}\text { Descanso da } \\
\text { Mufla }\end{array}$ & Polimerização \\
\hline Lucitone 550 & $21 \mathrm{~g} / 10 \mathrm{ml}$ & Fase Plástica & 30 minutos & $\begin{array}{c}\text { Imersão em água a } 73^{\circ} \mathrm{C}(90 \\
\text { minutos) e fervura }(30 \\
\text { minutos). }\end{array}$ \\
\hline Onda Cryl & $21 \mathrm{ml} / 7 \mathrm{ml}$ & Fase Fibrosa & $\begin{array}{c}30 \text { minutos a } \\
1 \text { hora }\end{array}$ & $\begin{array}{c}\text { Forno de Microondas c/ } \\
\text { potência de } 800 \text { a } 900 \text { watts: } 3 \\
\text { minutos a } 40 \%, 4 \text { minutos a } \\
0 \% \text { (mínima) e } 3 \text { minutos a } \\
90 \% .\end{array}$ \\
\hline
\end{tabular}


A resina convencional foi polimerizada em polimerizadora elétrica (Termocycler T100, Ribeirão Preto-SP, Brasil) e a resina para microondas em forno de microondas (Panasonic NN-S56B/56 28L, Manaus-AM, Brasil).

\subsection{Acabamento e polimento dos corpos-de-prova}

Após a desinclusão, os corpos-de-prova ficaram imersos em água destilada a $50^{\circ} \mathrm{C}$ por 24 horas em estufa (Odontobrás Ind. e com. equip. méd. odont. Ltda., Ribeirão Preto-SP, Brasil), para eliminação do monômero residual. Procedeu-se a eliminação das rebarbas com micromotor (Dabi Atlante SA Ind. Méd. Odontológicas, Ribeirão Preto-SP, Brasil) e fresa para recorte da resina acrílica (broca de carboneto de tungstênio- Labordental Ltda., São Paulo- SP). Simulando as superfícies de uma prótese total, uma das faces de cada corpo de prova recebeu acabamento e polimento, inicialmente, com lixas d'água (números 180, 220, 360 e 400 - Norton-Saint-Gobain Acessórios Ltda., Guarulhos-SP, Brasil) em politriz horizontal (DPU-10-Panambra Industrial e Técnica SA, São Paulo-SP, Brasil) e, posteriormente, em politriz de bancada (Nevoni, São Paulo-SP, Brasil) com rodas de algodão e branco de espanha (Branco Rio - Orlando Antonio Bussioli-ME, Rio Claro-SP, Brasil) (Fig. $6)$.

Após o polimento, as dimensões de cada corpo-de-prova foram conferidas com um paquímetro digital (CD-6" CSX-B - Mitutoyo Sul Americana Ltda., Suzano-SP, Brasil) e cada corpo-de- prova recebeu duas marcações com broca (PM 701 - Labordental Ltda., São 
Paulo- SP, Brasil), uma na face lateral para identificação e outra na face não polida para posicionamento no aparelho de medição de cor (Fig. 7).

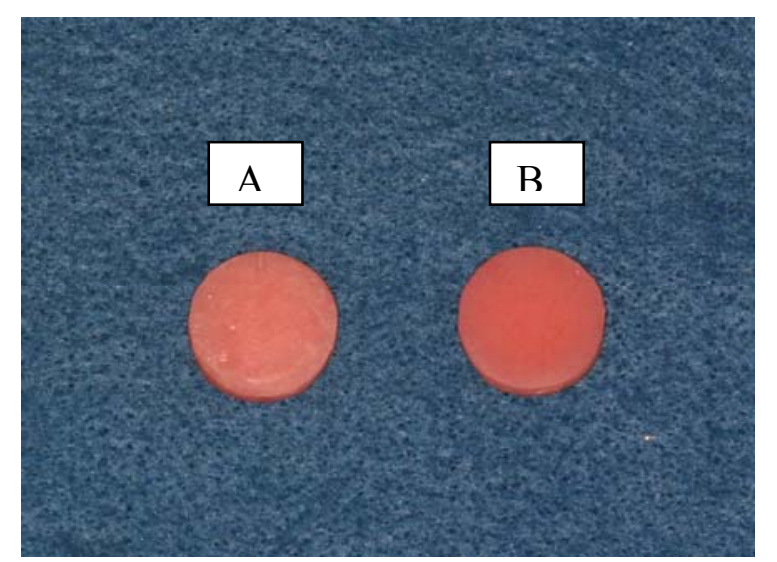

Figura 6: Corpos-de-prova em resina acrílica: A: face não polida; B: face polida.

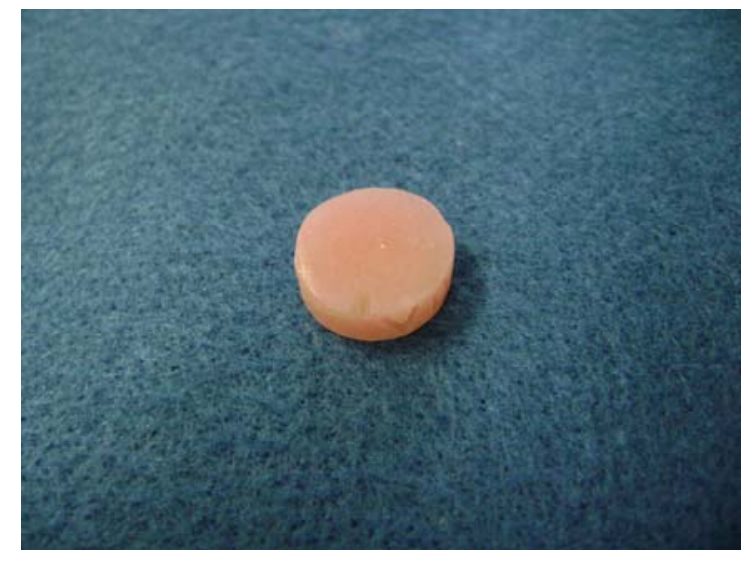

Figura 7: Face não-polida do corpo de prova com marcação.

Foram confeccionados 200 corpos-de-prova, 100 para cada resina acrílica (convencional e microondas).

\subsection{Produtos empregados}

Para cada tipo de resina, os grupos foram constituídos de 10 corpos-de-prova que foram imersos nas seguintes soluções: 
1) Controle $1(n=10)$ : Imersão em recipiente contendo água destilada a temperatura ambiente por 3 minutos/dia;

2) Experimental 1 ( $\mathrm{n}=10)$ : Imersão em recipiente contendo $200 \mathrm{ml}$ de água morna e 01 pastilha efervescente Bony Plus (Bonyf ag, Liechtenstein-Suíça) (Lote EC-86) pelo tempo recomendado pelo fabricante (3 minutos) (figura 8);

3) Controle 2 ( $n=10)$ : Imersão em recipiente contendo água destilada a temperatura ambiente por 5 minutos/dia;

4) Experimental 2 ( $\mathrm{n}=10)$ : Imersão em recipiente contendo $200 \mathrm{ml}$ de água morna e 01 pastilha efervescente Corega Tabs (Block Drug Company, Inc.-USA) (Lote 609022) pelo tempo recomendado pelo fabricante (5 minutos) (figura 9).

5) Controle $3(n=10)$ : Imersão em recipiente contendo água destilada a temperatura ambiente por 20 minutos/dia;

6) Experimental $3(n=10)$ : Imersão em recipiente contendo solução de hipoclorito de sódio a 0,5\% (solução manipulada, DATERRA-Farmácia de Manipulação-Ribeirão Preto-SP, Brasil) (Lote 1136600) por 20 minutos/dia (Figura 10);

7) Experimental $4(n=10)$ : Imersão em recipiente contendo solução de hipoclorito de sódio a 1\% (solução manipulada, DATERRA-Farmácia de Manipulação-Ribeirão Preto-SP, Brasil) (Lote 1136601) por 20 minutos/dia (Figura 11);

8) Controle $4(n=10)$ : Imersão em recipiente contendo água destilada a temperatura ambiente por 8 horas/dia;

9) Experimental $5(n=10)$ : Imersão em recipiente contendo solução de hipoclorito de sódio a $0,5 \%$ (solução manipulada, DATERRA-Farmácia de Manipulação-Ribeirão Preto-SP, Brasil) (Lote 1136600) por 08 horas/dia; 
10) Experimental $6(n=10)$ : Imersão em recipiente contendo solução de hipoclorito de sódio a 1\% (solução manipulada, DATERRA-Farmácia de Manipulação-Ribeirão Preto-SP, Brasil) (Lote 1136601) por 08 horas/dia.

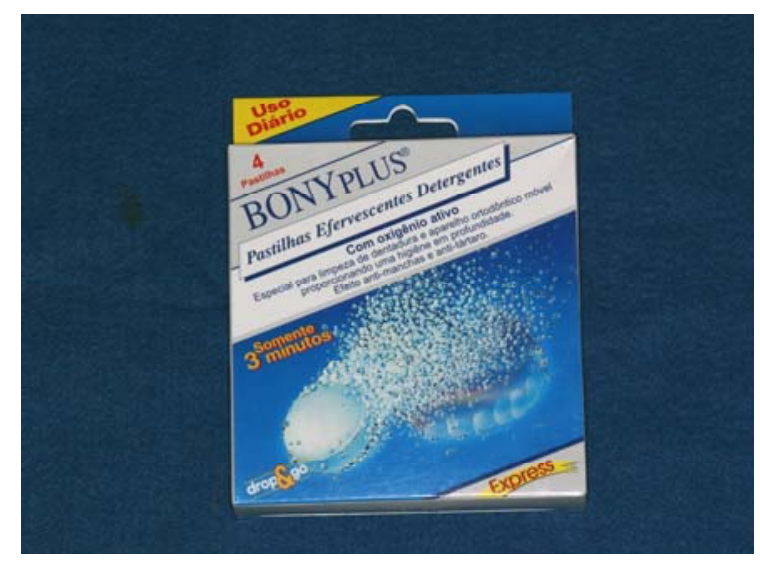

Figura 8: Pastilha efervescente Bony Plus

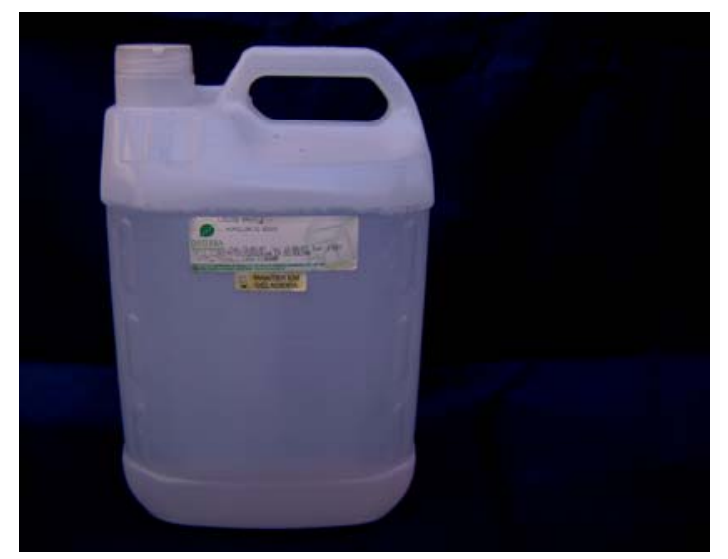

Figura 10: Hipoclorito de sódio $0,5 \%$.

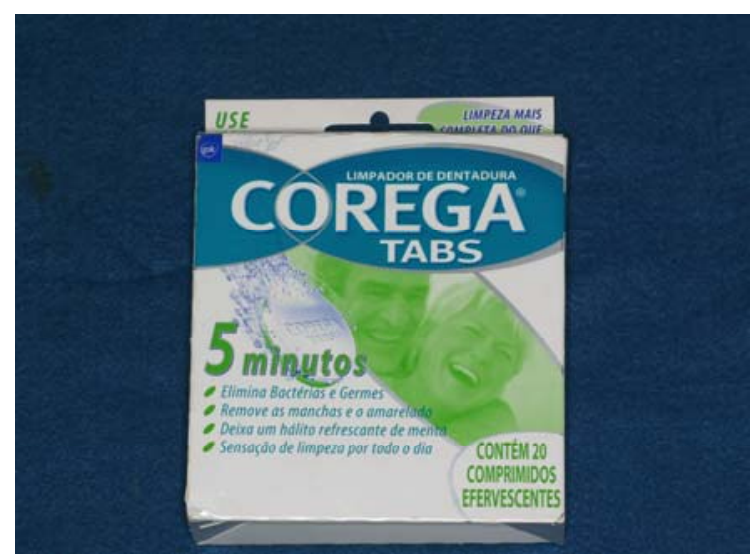

Figura 9: Pastilha efervescente Corega Tabs

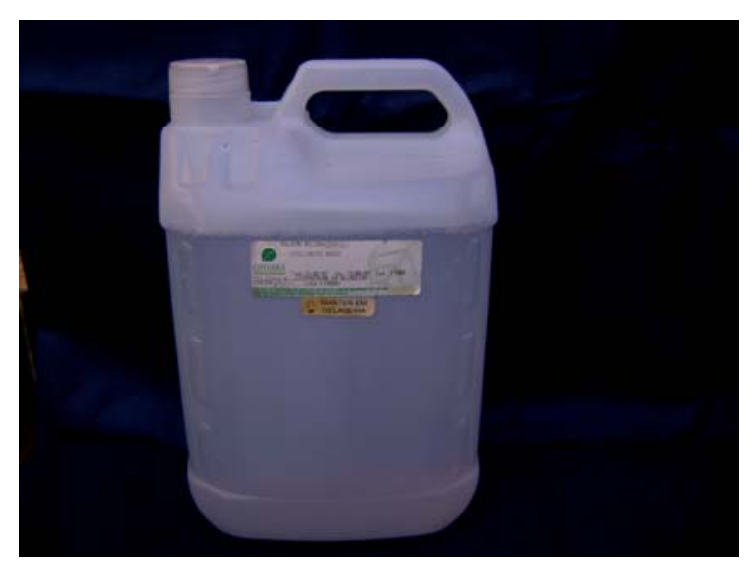

Figura 11: Hipoclorito de sódio 1\%. 


\subsection{Período de imersão}

As imersões simularam uma rotina de higiene de seis meses. Sendo assim, as soluções de hipoclorito de sódio e pastilhas efervescentes eram trocadas, após o tempo preconizado, por um período simulado de 180 dias.

Para as pastilhas efervescentes e soluções de hipoclorito de sódio $(0,5 \%$ e $1 \%)$, os corpos-de-prova foram imersos em recipientes contendo as soluções na temperatura recomendada pelo fabricante e temperatura ambiente, respectivamente. Em seguida, os corpos-de-prova eram enxaguados em água corrente, secos e uma nova solução era preparada e o procedimento era repetido. Este procedimento foi repetido por 180 vezes.

\subsection{Avaliação da alteração de cor}

Antes e após as imersões, os corpos-de-prova foram submetidos à leitura de cor utilizando-se o Espectrocolorímetro Portátil Modelo Color Guide 45/0 (BYK - Gardner GmbH- Geretsried-Alemanha) (Fig. 12 e 13). 


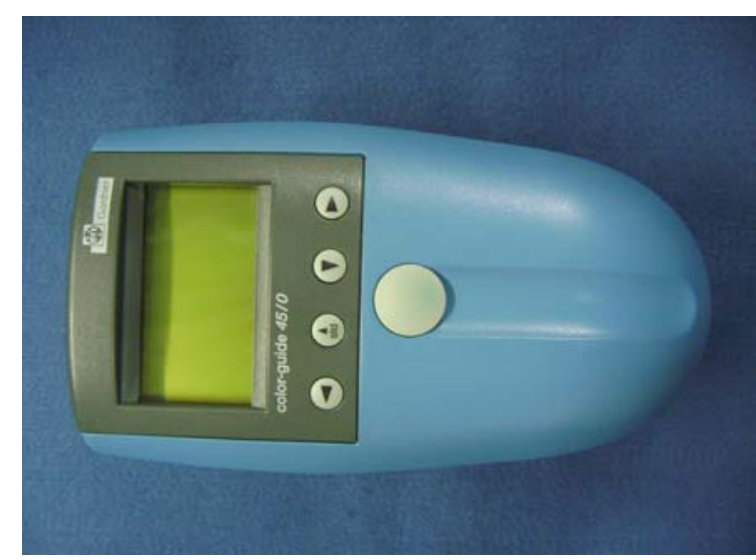

Figura 12: Espectrocolorímetro (vista frontal)

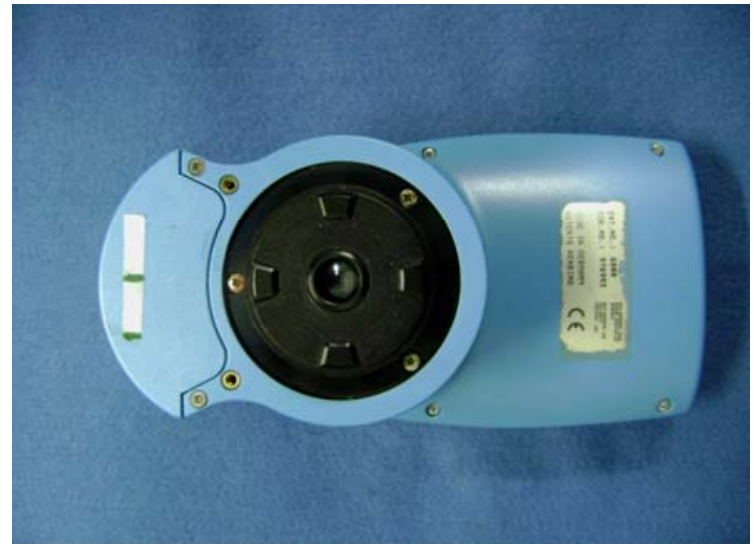

Figura 13: Espectrocolorímetro (vista posterior)

As amostras eram retiradas das soluções de imersão, enxaguadas em água corrente e permaneciam em água destilada até a leitura de cor final. Antes de serem levadas ao espectrocolorímetro, as amostras eram secas com lenços de papel.

Para a leitura de cor, os corpos-de-prova eram secos com lenços de papel e posicionados no aparelho, sendo sua superfície polida voltada para a abertura de medição de cor e a marcação feita em sua face não-polida, voltada para a parte anterior do equipamento (Fig. 14, 15 e 16). Esta técnica de posicionamento possibilitou que a leitura de cor fosse realizada na mesma região do corpo de prova, antes e após as imersões. 


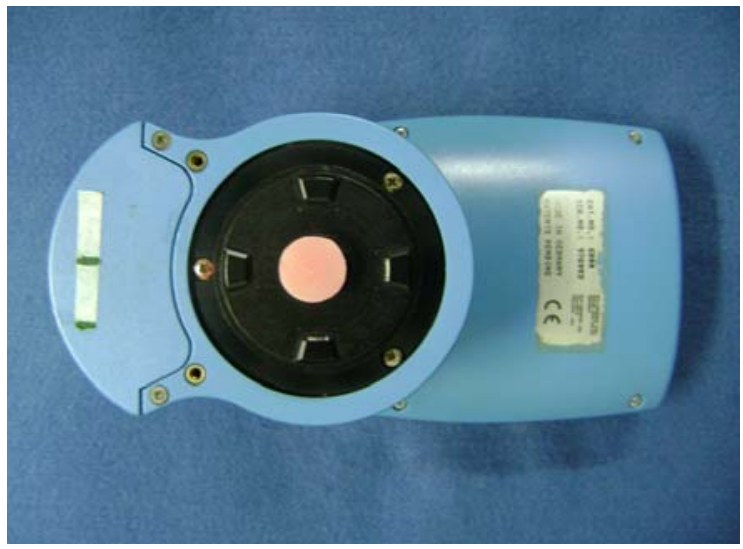

Figura 14: Corpo de prova posicionado no espectrocolorímetro.

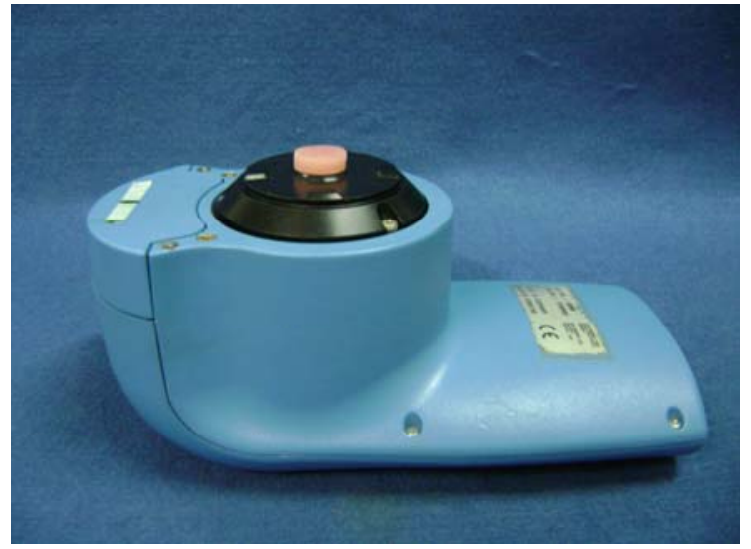

Figura 15: Corpo de prova posicionado no espectrocolorímetro.

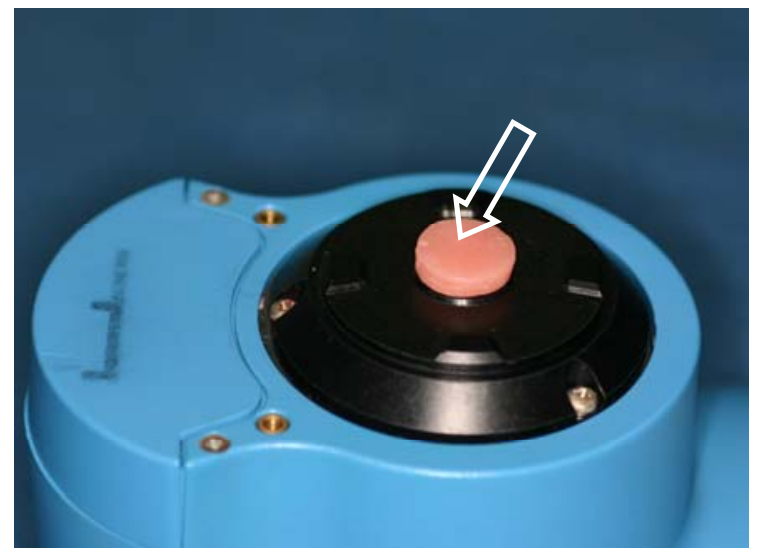

Figura 16: Corpo de prova posicionado no espectrocolorímetro - marcação na face não polida.

Para eliminar a diferença de cor no segundo plano, sobre o corpo de prova posicionado no aparelho foi colocado um artefato branco (POWERS; LEPEAK ${ }^{86}$, 1977) (Fig. 17), utilizado como um segundo plano para coleta dos dados para eliminar os efeitos de diferenças de cor durante as medidas_(Fig. 18). 


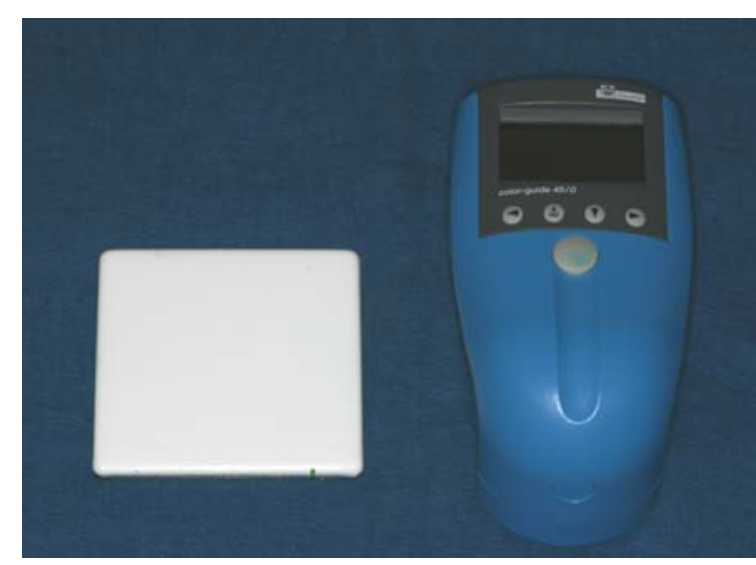

Figura 17: Espectrocolorímetro e segundo plano branco.

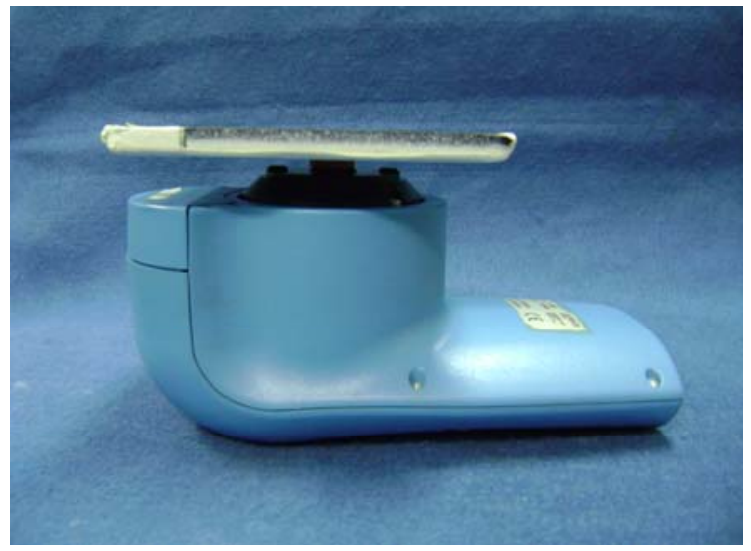

Figura 18: Corpo-de-prova e placa posicionados para realização da leitura de cor.

As medidas de cor foram obtidas no sistema de cor CIELab, recomendado pela Commission Internationale de l'Eclairage (CIE) (BUYUKILMAZ; RUYTER ${ }^{23}$, 1994; JIN et al. $^{45}$, 2003; LIBERMAN et al. ${ }^{57}, 1995$; MA, JOHNSON; GORDON ${ }^{58}, 1997$; POLYZOIS et al. $\left.^{85}, 1997\right)$. Este consiste de dois eixos $a^{*}$ e b* que estão em ângulo reto e representam a dimensão do matiz ou cor, representando o vermelho $\left(+\mathrm{a}^{*}\right)$ e verde $\left(-\mathrm{a}^{*}\right)$, amarelo $\left(+\mathrm{b}^{*}\right)$ e azul $\left(-b^{*}\right)$. O terceiro eixo é a claridade $\mathrm{L}^{*}$, que é perpendicular ao plano $\mathrm{a}^{*} \mathrm{~b}^{*}$, e representa o grau de claro e escuro do objeto representado pelo valor de $L^{*}$, sendo $L^{*}=100$ para branco e $\mathrm{L}^{*}=0$ para preto.

Utilizou-se iluminação padronizada D65, que simula o espectro de luz do dia e ângulo de observação de $10^{\circ}$. O aparelho emitiu fonte de luz com espectro visível (ondas na faixa de 400 a 700nm) sobre o objeto e mediu a reflexão deste espectro.

Após o acionamento do aparelho, este emitiu um feixe de luz. A geometria de medição foi $45 / 0$, ou seja, emissão de iluminação circular de $45^{\circ}$ e reflexão do feixe em $0^{\circ}$ de volta para o aparelho e assim, este captou e registrou os valores de $\mathrm{L}^{*}, \mathrm{a}^{*}$ e $\mathrm{b}^{*}$ de cada corpo-deprova. O aparelho possui uma abertura de medição de cor de $11 \mathrm{~mm}$. 
A mudança total de cor $(\Delta \mathrm{E})$ foi calculada automaticamente pelo aparelho, por meio da seguinte fórmula:

$$
\Delta \mathrm{E}^{*}=\left[\left(\Delta \mathrm{L}^{*}\right)^{2}+\left(\Delta \mathrm{a}^{*}\right)^{2}+\left(\Delta \mathrm{b}^{*}\right)^{2}\right]^{1 / 2}
$$

Foram medidos os valores de $\mathrm{L}^{*}, \mathrm{a}^{*}, \mathrm{~b}^{*}$ de cada amostra antes e depois das imersões. Os valores de $\Delta \mathrm{L}^{*}, \Delta \mathrm{a}^{*}$ e $\Delta \mathrm{b}^{*}$ foram calculados automaticamente, onde $\Delta \mathrm{L}^{*}, \Delta \mathrm{a}^{*}$ e $\Delta \mathrm{b}^{*}$ corresponderam à diferença dos valores de $\mathrm{L}^{*}, \mathrm{a}^{*}, \mathrm{~b}^{*}$, respectivamente, antes e após as imersões:

$$
\begin{gathered}
\Delta \mathrm{L}^{*}=\mathrm{L}_{\mathrm{f}}^{*}-\mathrm{L}_{\mathrm{i}}^{*} \\
\Delta \mathrm{a}^{*}=\mathrm{a}_{\mathrm{f}}^{*}-\mathrm{a}_{\mathrm{i}}^{*} \\
\Delta \mathrm{b}^{*}=\mathrm{b}_{\mathrm{f}}^{*}-\mathrm{b}_{\mathrm{i}}^{*}
\end{gathered}
$$

onde $\mathrm{L}_{\mathrm{i}}^{*}, \mathrm{a}_{\mathrm{i}}^{*} \mathrm{e} \mathrm{b}_{\mathrm{i}}{ }^{*}$ correspondem a medição inicial da cor e $\mathrm{L}_{\mathrm{f}}^{*}, \mathrm{a}_{\mathrm{f}}^{*} \mathrm{e} \mathrm{b}_{\mathrm{f}}$ * correspondem a medição final da cor.

\subsection{Análise dos dados}

Uma análise descritiva foi realizada por meio de gráficos, onde as barras representam as médias, uma vez que a distribuição foi próxima à normal para a maioria dos grupos. Os 
resultados para as mudanças de cor foram comparados por meio da análise de variância (ANOVA) para dois fatores, seguida pelo teste de Student-Newman Keuls para comparações posteriores. Interação significante foi avaliada por meio de comparações entre pares dentro de cada material. O nível de significância foi de 0,05 .

Além dessa análise, para correlacionar as diferenças de cor $\left(\Delta \mathrm{E}^{*}\right)$ para o ambiente clínico, os dados foram calculados de acordo com as unidades da National Bureau of Standards (NBS) (POLYZOIS et al. ${ }^{85}$, 1997) por meio da fórmula:

$$
\text { Unidades } \mathrm{NBS}=\Delta \mathrm{E}^{*} \times 0,92
$$

As classificações estão apresentadas na Tabela 2:

Tabela 2: National Bureau of Standards (NBS) Sistema de Expressão de diferença de cor.

\begin{tabular}{lc}
\hline Classificações de diferença de cor & Unidades NBS \\
\hline Indicial & $0,0-0,5$ \\
Leve & $0,5-1,5$ \\
Perceptível & $1,5-3,0$ \\
Considerável & $3,0-6,0$ \\
Muito & $6,0-12,0$ \\
Excessiva & $12,0-+$ \\
\hline
\end{tabular}


5 Resultados 
Os resultados originais ( $\mathrm{L}, \mathrm{a}, \mathrm{b}, \Delta \mathrm{L}, \Delta \mathrm{a}, \Delta \mathrm{b}$ e $\Delta \mathrm{E}$ ) estão apresentados nos Apêndice A (Tabelas A1 a A9).

A Tabela 3 mostra os resultados de $\Delta \mathrm{E}^{*}$ (alteração de cor) para as resinas avaliadas, em função de cada tratamento.

Tabela 3. Resultados médios ( \pm desvio padrão) para as resinas e tratamentos testados.

\begin{tabular}{|c|c|c|c|c|c|c|c|c|c|c|}
\hline & \multicolumn{2}{|c|}{3 minutos } & \multicolumn{2}{|c|}{5 minutos } & \multicolumn{3}{|c|}{20 minutos } & \multicolumn{3}{|c|}{8 horas } \\
\hline & Água & BP* & Água & $\mathrm{CT}^{*}$ & Água & $\begin{array}{c}\text { HS* } \\
0,5 \%\end{array}$ & $\begin{array}{l}\text { HS * } \\
1 \%\end{array}$ & Água & $\begin{array}{l}\text { HS* } \\
0,5 \%\end{array}$ & $\begin{array}{l}\text { HS* } \\
1 \%\end{array}$ \\
\hline OC* & $\begin{array}{c}0,22 \\
\pm 0,08\end{array}$ & $\begin{array}{r}0,43 \\
\pm 0,32\end{array}$ & $\begin{array}{c}0,65 \\
\pm 0,35\end{array}$ & $\begin{array}{c}0,41 \\
\pm 0,11\end{array}$ & $\begin{array}{c}0,31 \\
\pm 0,11\end{array}$ & $\begin{array}{c}0,29 \\
\pm 0,07\end{array}$ & $\begin{array}{c}0,37 \\
\pm 0,11\end{array}$ & $\begin{array}{c}0,78 \\
\pm 0,10\end{array}$ & $\begin{array}{r}0,79 \\
\pm 0,08\end{array}$ & $\begin{array}{r}1,06 \\
\pm 0,13\end{array}$ \\
\hline $\mathbf{L}^{*}$ & $\begin{array}{c}0,27 \\
\pm 0,10\end{array}$ & $\begin{array}{r}0,44 \\
\pm 0,21\end{array}$ & $\begin{array}{c}0,48 \\
\pm 0,21\end{array}$ & $\begin{array}{c}0,46 \\
\pm 0,13\end{array}$ & $\begin{array}{r}0,29 \\
\pm 0,07\end{array}$ & $\begin{array}{c}0,37 \\
\pm 0,08\end{array}$ & $\begin{array}{c}0,47 \\
\pm 0,10\end{array}$ & $\begin{array}{c}0,61 \\
\pm 0,11\end{array}$ & $\begin{array}{r}0,55 \\
\pm 0,10\end{array}$ & $\begin{array}{r}0,74 \\
\pm 0,09\end{array}$ \\
\hline
\end{tabular}

*Abreviaturas: $\mathrm{BP}=$ Bony Plus; $\mathrm{CT}=$ Corega Tabs; $\mathrm{HS}=$ Hipoclorito de sódio; $\mathrm{OC}=$ Resina Onda Cryl; L = Resina Lucitone 550.

Observa-se que em todas as situações ambos os materiais sofreram modificação de cor, apesar de que, em nenhum momento, esse efeito foi pronunciado. É possível observar que algumas situações, como a imersão em hipoclorito de sódio ou água levou a médias mais elevadas, quando um regime de oito horas foi simulado.

A tabela 4 mostra os resultados do teste estatístico empregado. 
Tabela 4. ANOVA para dois fatores, mudança de cor após imersão.

\begin{tabular}{cccccc}
\hline & SQ & gl & QM & F & P \\
\hline Tratamento & 7,66 & 9 & 0,85 & 36,11 & $<0,001^{*}$ \\
Resina & 0,19 & 1 & 0,19 & 8,21 & $0,005^{*}$ \\
Interação & 1,01 & 9 & 0,11 & 4,74 & $<0,001^{*}$ \\
Erro & 4,24 & 180 & 0,02 & & \\
Total & 13,10 & 199 & & & \\
\hline
\end{tabular}

*Diferença significante $(\alpha=0,05)$.

Observou-se que os tratamentos influenciaram as mudanças de cor, e as diferentes resinas apresentaram estabilidades de cor distintas. A resina Lucitone 550 apresentou-se discretamente mais estável do que a Onda-Cryl $(\Delta \mathrm{E}=0,47 \pm 0,18$ e $0,53 \pm 0,31$, respectivamente). Por outro lado, a interação foi significante, o que indica que, para cada resina, o efeito dos tratamentos foi diferente.

As Figs. 19 e 20 representam os resultados para as resinas Onda-Cryl e Lucitone, respectivamente.

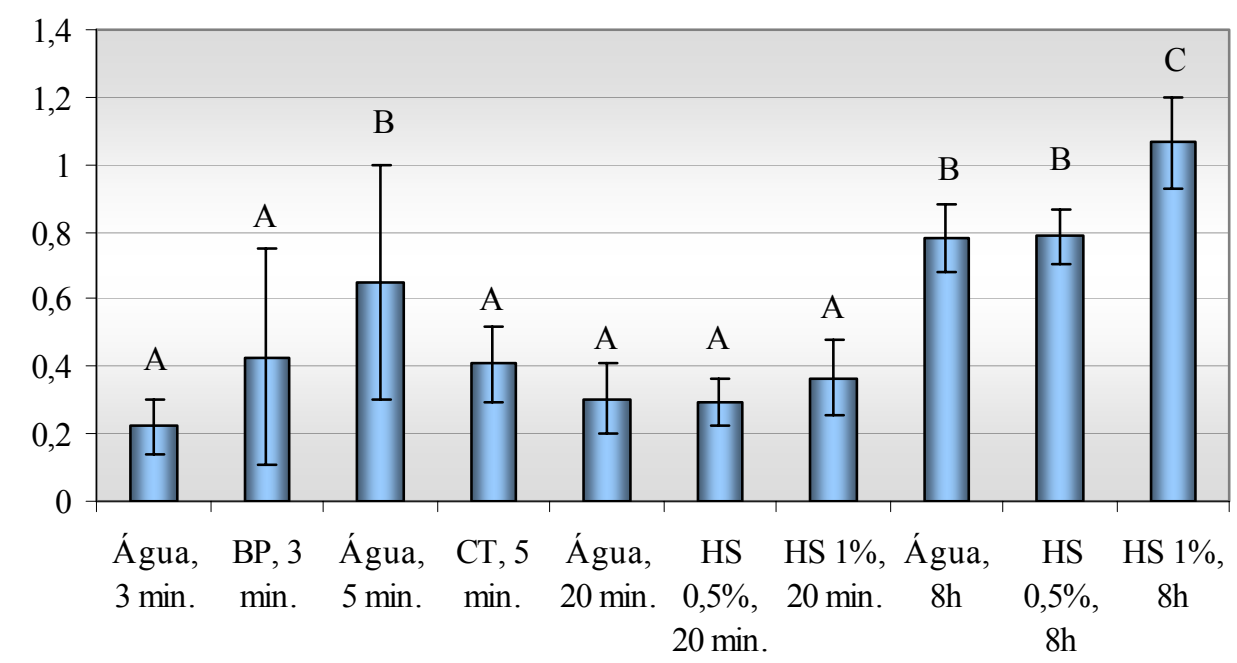

Figura 19: Valores médios e desvio padrão para os dez grupos avaliados da resina de microondas (Onda Cryl). As barras horizontais representam os resultados do teste de Student-Newman-Keuls, onde a mesma letra representa semelhança estatística. 


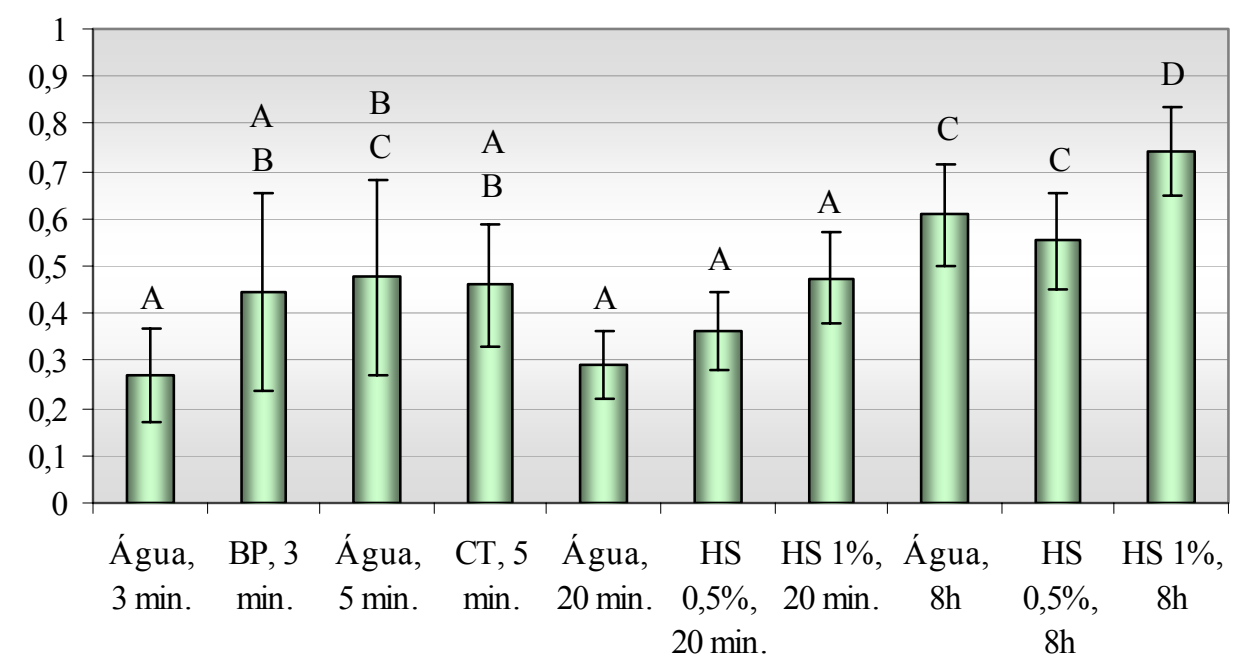

Figura 20: Valores médios e desvio padrão para os dez grupos avaliados da resina termopolimerizável convencional (Lucitone 550). As barras horizontais representam os resultados do teste de Student-Newman-Keuls, onde a mesma letra representa semelhança estatística.

Para a resina Onda-Cryl, as pastilhas efervescentes, bem como os regimes de imersão em hipoclorito por 20 minutos, não provocaram alteração significantemente maior que seus respectivos controles em água destilada. A imersão em hipoclorito a $0,5 \%$ por tempo prolongado, simulando o uso diário por oito horas, não provocou maiores alterações que a água por tempo semelhante. A solução a $1 \%$, por sua vez, levou a maiores alterações quando comparada à imersão na concentração menor ou em água destilada. Um resultado semelhante foi observado para a resina Lucitone 550, exceto por uma tendência das pastilhas efervescentes apresentarem resultados intermediários entre o controle de 3 minutos e valores mais elevados, como o controle de 5 minutos.

Posteriormente, os dados foram calculados de acordo com as unidades NBS (National Bureau of Standards) (Tabela 5). Os resultados de alteração de cor, calculados de acordo com a NBS, para cada corpo-de-prova estão apresentados no Apêndice B (Tabela B1). 
Tabela 5: Valores médios de $\Delta \mathrm{E}$ calculados de acordo com a NBS.

\begin{tabular}{c|cc|cc|ccc|ccc}
\hline & \multicolumn{2}{|c|}{$\mathbf{3}$ minutos } & \multicolumn{2}{|c|}{$\mathbf{5}$ minutos } & \multicolumn{3}{c|}{$\mathbf{2 0}$ minutos } & \multicolumn{3}{c}{$\mathbf{8}$ horas } \\
\hline & Água & $\mathbf{B P *}$ & Água & $\mathbf{C T} *$ & Água & $\mathbf{H S} *$ & $\mathbf{H S} *$ & & HS* & HS* \\
& & & & & & $\mathbf{0 , 5 \%}$ & $\mathbf{1 \%}$ & & $\mathbf{0 , 5 \%}$ & $\mathbf{1 \%}$ \\
\hline $\mathbf{O C}^{*}$ & 0,21 & 0,39 & 0,60 & 0,38 & 0,28 & 0,27 & 0,34 & 0,72 & 0,72 & 0,98 \\
\hline $\mathbf{L}^{*}$ & 0,25 & 0,41 & 0,44 & 0,42 & 0,27 & 0,34 & 0,44 & 0,56 & 0,51 & 0,68 \\
\hline
\end{tabular}

*Abreviaturas: $\mathrm{BP}=$ Bony Plus; $\mathrm{CT}=$ Corega Tabs; $\mathrm{HS}=$ Hipoclorito de sódio; $\mathrm{OC}=$ Resina Onda Cryl; L = Resina Lucitone 550.

De acordo com a Tabela 5, observou-se que os tratamentos nas resinas acrílicas (termopolimerizável e microondas) provocaram alterações de cor classificadas como indiciais e leves, pois todos os valores estiveram abaixo de 0,98 e as imersões durante o período de 8 horas apresentaram alterações de cor classificadas como leve, de acordo com a NBS. 
6 Discussão 
Este estudo avaliou a alteração de cor de duas resinas acrílicas termopolimerizáveis, submetidas à imersão em pastilhas efervescentes (Corega Tabs e Bony Plus), hipocloritos de sódio $(0,5 \%$ e $1 \%)$ e água destilada (grupo controle), simulando, em laboratório, os procedimentos de higienização utilizados por usuários de próteses totais durante um período de 180 dias. As imersões foram realizadas utilizando-se água à temperatura ambiente (soluções controle e de hipocloritos) e na temperatura indicada pelo fabricante (pastilhas efervescentes).

Para a realização das leituras de cor, similarmente a outros estudos (BUYUKILMAZ; RUYTER $^{23}$, 1994; JIN et al. ${ }^{45}, 2003$; LIBERMAN et al. ${ }^{57}, 1995$; MA, JOHNSON; GORDON $^{58}$, 1997; MALHEIROS-SEGUNDO ${ }^{60}$, 2007; POLYZOIS et al. ${ }^{85}$, 1997) foi utilizado um espectrocolorímetro, sendo as medidas de cor obtidas no sistema de cor CIELab, recomendado pela Commission Internationale de l'Eclairage (CIE). Também foi utilizada uma iluminação padronizada que simula o espectro de luz do dia, sendo a mudança de cor calculada automaticamente pelo aparelho.

Os diferentes métodos de polimerização das resinas acrílicas podem alterar as suas propriedades físicas e mecânicas (LAI et al. ${ }^{55}$, 2004). Neste trabalho, incorporou-se duas resinas, uma termopolimerizável e uma resina polimerizada por energia de microondas, por serem amplamente empregadas na confecção de próteses totais. A tabela 4 mostra que houve diferença entre as resinas empregadas, sendo que a resina termopolimerizável convencional (Lucitone 550) apresentou maior estabilidade de cor $(\Delta \mathrm{E}=0,47 \pm 0,18)$ do que a resina de microondas (Onda Cryl) $(\Delta \mathrm{E}=0,53 \pm 0,31)$. Embora haja variação entre as resinas quanto à susceptibilidade ao branqueamento (ROBINSON; MCCABE; STORER ${ }^{89}$, 1987), as diferentes procedências dos produtos, apresentando diferentes composições, podem também justificar as diferenças ocorridas. É possível que o plastificador presente nas resinas influencie o branqueamento $\left(\mathrm{SMITH}^{100}, 1966\right)$, que pode ocorrer devido à ação degradante em 
moléculas de corantes ou pigmentos utilizados por determinados fabricantes. Diferenças nos agentes de ligação cruzada podem influenciar o branqueamento da resina acrílica.

Um fator que deve ser destacado refere-se aos cuidados em relação à correta polimerização das resinas acrílicas. Tem sido sugerido que a polimerização incorreta das próteses de resina acrílica, como a utilização de baixas temperaturas ou tempo reduzidos, resulta em altos níveis de monômero residual (AUSTIN; BASKER ${ }^{12}, 1982$ ), que poderiam reagir com solventes externos e reagentes, conduzindo ao branqueamento (ROBINSON; MCCABE; STORER ${ }^{90,89}$, 1985, 1987; ÜNLÜ; ALTAY; SAHMALI ${ }^{105}$, 1996). No entanto, Arab, Newton e Lloyd $d^{9}$ (1989) concluíram que um elevado nível de monômero residual não é o principal fator no branqueamento da resina acrílica. Contudo, isto não descarta a proposição de que altos níveis de monômero façam das próteses de pacientes diabéticos que possuem hálito cetônico mais suscetíveis ao clareamento (ROBINSON; MCCABE; STORER ${ }^{89}$, 1987). Segundo Robinson, McCabe e $\operatorname{Storer}^{89}$ (1987) o monômero residual pode exacerbar efeitos de solvatização (associação de moléculas de soluto e solvente formando um solvato) que são acelerados pelo aumento da temperatura. A causa mais provável de branqueamento é a combinação de alta temperatura e exposição a solvente.

Trabalhos específicos sobre o efeito de higienizadores de prótese sobre a propriedade de cor de resinas acrílicas indicam que as resinas quimicamente ativadas são mais suscetíveis às alterações de cor (PAZZINI; MUTTI; PAZZINI ${ }^{83}$, 1972; PURNAVEJA et al. ${ }^{87}, 1982$ ) e que as resinas termopolimerizáveis apresentam maior estabilidade (MA; JOHNSON; GORDON ${ }^{58}$, 1997; MCNEME; VON GONTEM; WOOLSEY ${ }^{67}$, 1991; POLYZOIS et al. ${ }^{85}$, 1997; ÜNLÜ; ALTAY; SAHMALI ${ }^{105}$, 1996). Trabalhos comparativos entre resinas convencionais e de microondas não têm sido amplamente relatados.

As soluções químicas têm sido amplamente recomendadas para higienização de próteses totais $\left(\mathrm{SHAY}^{97}, 2000\right)$. Em alguns estudos, onde foram comparadas com grupos controles 
constituídos de água, tais soluções apresentaram efetividade limitada (KENG; LIM, 1996 ; NICHOLSON; STARK; SCOTT ${ }^{74}$, 1968). Porém, quantificações microbiológicas (NAKAMOTO; TAMAMOTO; HAMADA ${ }^{71}$, 1991) e metodologias de evidenciação de biofilme (GORNITSKY et al. ${ }^{40}, 2002$; MCCABE; MURRAY; KELLY ${ }^{65}$, 1995; MINAGI et al. $^{68}, 1987$; SHEEN; HARRISON $\left.{ }^{98}, 2000\right)$ têm demonstrado efetividade de tais produtos. Tais diferenças podem ser atribuídas à diversidade das metodologias empregadas, tornando difícil comparações diretas dos resultados obtidos (NIKAWA et al. ${ }^{76}$, 1999). A associação com aparelhos ultra-sônicos também é relatada (ABELSON ${ }^{1}, 1981$; RAAB et al. $\left.{ }^{88}, 1991\right)$, porém a recomendação mais comum e efetiva, refere-se à sua associação com o método mecânico de escovação (BARNABÉ et al. ${ }^{14}$, 2004; CHAN et al. ${ }^{24}$, 1991; DILLS et al. ${ }^{35}$, 1988; PARANHOS et al. $\left.{ }^{80}, 2007\right)$.

Os resultados mostraram que as pastilhas efervescentes (Corega Tabs e Bony Plus) não provocaram alterações significativamente maiores que seus respectivos controles em água destilada. Segundo a classificação NBS, tais alterações foram classificadas como "indiciais" (tabela 5). Um fator contribuinte para esse resultado foi o uso dos produtos nos tempos, concentrações e temperaturas recomendadas pelos fabricantes.

A temperatura da água usada pelos pacientes em seus procedimentos de limpeza de próteses totais é um fator crítico, resultando em um branqueamento da resina acrílica quando da utilização de altas temperaturas (ARAB; NEWTON; LLOYD ${ }^{10,}$, , 1988, 1989; CRAWFORD et al. ${ }^{30}$, 1986; CRAWFORD; NEWTON; YEMM ${ }^{29}$, 1987; DEVLIN; KAUSHIK $^{33}$, 2005; ROBINSON; MCCABE; STORER ${ }^{89}$, 1987), sendo que resinas polimerizadas corretamente não são branqueadas pelo higienizador peróxido alcalino quando usado na concentração e temperatura recomendada pelo fabricante (ARAB; NEWTON; LLOYD $^{10}$, 1988; CRAWFORD et al. ${ }^{30}$, 1986; ROBINSON; MCCABE; STORER ${ }^{90,89}, 1985$, 1987; SATO et al. ${ }^{93}$, 2005; DEVLIN; KAUSHIK ${ }^{33}$, 2005). 
Os resultados obtidos neste estudo concordam com Sato et al. ${ }^{93}$ (2005) que não detectaram alterações de cor de resinas acrílicas termopolimerizáveis após imersão (15 minutos e 8 horas) em Bony Plus, Corega Tabs e Efferdent Plus, porém foram simulados 30 dias de uso. Robinson, McCabe e Storer $^{90}$ (1985) realizaram tratamento por um ano de corpos de prova de resinas termopolimerizáveis em peróxido alcalino (Steradent) e também não detectaram branqueamento.

Nossos achados discordam de Ünlü, Altay e Sahmali ${ }^{105}$ (1996), que detectaram alteração de cor em amostras de resinas (autopolimerizáveis e termopolimerizáveis) com o uso de higienizadores químicos (Polident, Efferdent, Blend-A-Dent e Corega) em estudo simulando 30 noites de imersão (240 horas), sendo que o produto Corega (Stafford-Miller Limited Hatfield) provocou o maior efeito de branqueamento nas resinas, e o Polident, o menor. Neste estudo, porém, o higienizador Corega continha agentes de liberação de oxigênio com enzimas, sustentando a hipótese de que a oxidação em combinação com uma solução alcalina forte pode ser deletéria. Os produtos Efferdent e Polident produzem $\mathrm{CO}_{2}$ quando dissolvidas em água (GHALICHEBAF $\left.{ }^{38}, 1982\right)$, mostrando um mínimo efeito de branqueamento.

Pesquisas têm sido relatadas sobre a ação bactericida e as diversas concentrações e tempos de imersão do hipoclorito de sódio para que se seja obtida a desinfecção ou esterilização das resinas (BELL; BROCKMANN; SACKUVICH ${ }^{18}, 1989$; CHAU et al. ${ }^{25}$, 1995; GARCIA JUNIOR ${ }^{37}, 2002$; RUDD et al. ${ }^{91}$, 1984; WEBB et al. ${ }^{109}$, 1998). Embora contra-indicado em aparelhos protéticos com componentes metálicos (BACKENSTOSE, WELLS $^{13}$, 1977; KEYF; GÜNGÖR $\left.{ }^{48}, 2003\right)$, o hipoclorito de sódio tem sido indicado como higienizador diário de próteses totais convencionais, visando o controle do biofilme (GHALICHEBAF; GRASER; ZANDER ${ }^{38}, 1982$; KEMPLER et al. ${ }^{46}, 1982$; WATKINSON; MCCREIGHT; WORNOCK ${ }^{108}$, 1985), inclusive como soluções para imersões noturnas 
(BASSON; QUICK; THOMAS ${ }^{15}$, 1992; HUTCHINS; PARKER ${ }^{42}, 1973$; KULAK et al. ${ }^{51}$, 1997; WEBB; THOMAS; WHITTLE ${ }^{110}$, 2005). Tais produtos têm mostrado ação sobre manchas (JAGGER et al. $\left.^{43}, 2002\right)$ e efetividade aumentada quando associados ao método mecânico de escovação e ao uso com ultra-som (NICHOLSON; STARK; SCOTT $^{74}, 1968$ ). Basson, Quick e Thomas ${ }^{15}$ (1992) verificaram que a imersão das próteses durante a noite em uma solução fraca de hipoclorito $(0,012 \%$ e $0,04 \%)$ reduziu o número de bactérias, acúmulo de biofilme e depósitos orgânicos, assim como Kulak et al. ${ }^{51}$ (1997) que a imersão da prótese em hipoclorito $5 \%$ durante a noite foi eficaz na remoção de contaminantes. Webb et al. ${ }^{111}$ (1995) verificaram que o hipoclorito pode funcionar como um efetivo agente antifúngico quando usado para imersão das próteses em casos de estomatite de dentadura. Porém a ação do hipoclorito de sódio frente à propriedade de cor de resinas acrílicas em períodos prolongados de imersão não tem sido amplamente relatada.

Os tempos de imersão empregados para as soluções de hipoclorito foram instituídos, buscando simular as orientações fornecidas aos pacientes para a higienização diária de próteses totais, ou seja, 20 minutos (período curto de imersão) ou 08 horas (durante o período do sono). Analisando as soluções empregadas pelo tempo de 20 minutos $(0,5 \%$ e $1 \%)$, os resultados mostraram que não houve diferença significativa quando comparadas ao controle (água por 20 minutos). Também não apresentaram diferenças quando comparadas entre si e com as pastilhas efervescentes (Fig. 19 e 20). De acordo com a classificação da NBS, as alterações de cor causadas foram classificadas como "indiciais". Com relação à imersão por 08 horas, diferenças, porém, foram encontradas quando as soluções de hipoclorito de sódio a $1 \%$, foram comparadas com os controles e imersões na concentração menor $(0,5 \%)$, sugerindo que tais soluções provocam alterações de cor classificadas como "leves" de acordo com a NBS, pelo período simulado de 180 dias. 
Tais alterações foram maiores que os grupos de hipoclorito $(0,5 \%$ e $1 \%)$ por 20 minutos/dia e pastilhas efervescentes. Estes resultados estão de acordo com Ma; Johnson e Gordon $^{58}$ (1997) que concluíram que a imersão em hipoclorito de sódio por 7 dias levou ao clareamento das resinas, porém os autores empregaram o hipoclorito a 5,25\%. McNeme, Von Gontem e Woolsey ${ }^{67}$ (1991) e Polyzois et al. ${ }^{85}$ (1997) não encontraram alterações de cor em resinas acrílicas após o uso do hipoclorito de sódio em diversas concentrações $(1 \% ; 5,25 \%$; 0,525\%), porém os tempos de imersão empregados foram menores, ou seja, 72 horas e 7 dias, respectivamente.

Segundo Robinson, McCabe e Storer $^{90,89}$ (1985, 1987), os possíveis mecanismos responsáveis pelo branqueamento das próteses são a manipulação incorreta da resina acrílica e o ataque por agentes externos, como higienizadores de prótese e solventes (por exemplo, cetona). A manipulação incorreta da resina se deve à inclusão de óleos ou umidade das mãos do operador quando este está manipulando a resina, causando deterioração dentro da massa. O branqueamento ocorre principalmente na superfície da prótese (CRAWFORD et al. ${ }^{30}, 1986$; ROBINSON; MCCABE; STORER $\left.{ }^{90}, 1985\right)$. Robinson, McCabe e Storer ${ }^{90}$ (1985) observando próteses branqueadas constataram que o branqueamento ocorre tanto na superfície polida como na superfície de assentamento.

A água destilada usada para imersão dos corpos de prova por um período de 8 horas e 5 minutos (Onda Cryl) mostrou mudanças de cor, classificadas como "leves" de acordo, com a classificação NBS A água pode levar a efeitos deletérios nas propriedades mecânicas da resina acrílica. Segundo Devlin e Kaushik ${ }^{33}$ (2005), suas moléculas interferem com a cadeia polimérica do polímero e atuam como plastificantes. Os efeitos da água nas resinas acrílicas são interessantes do ponto de vista clínico, uma vez que a recomendação da imersão do aparelho protético em água durante a noite é freqüente. 
Uma limitação desse estudo refere-se ao fato de não terem sido reproduzidas determinadas condições orais no planejamento metodológico, como a associação dos corpos de prova à presença de biofilme, variável que pode influenciar a ação de soluções higienizadoras (KENG; LIM $^{47}$, 1996; PARANHOS et al. ${ }^{80}, 2007$ ).

Sendo assim, estudos laboratoriais devem ser conduzidos com a simulação do ambiente oral e de um maior tempo de imersão, uma vez que o tempo de troca de uma prótese total convencional está compreendido entre 05 a 07 anos (ZARB; BOLENDER; CARLSSON ${ }^{114}$, 2000). O estudo da ação de higienizadores sobre a rugosidade superficial e resistência à flexão de resinas acrílicas também se faz importante, uma vez que constituem-se em importantes propriedades da resina acrílica. 
7 Conclusões 
Com base na metodologia empregada e pela análise dos dados obtidos, pode-se concluir que:

1) Houve diferença entre as resinas empregadas (convencional Lucitone e microondas Onda Cryl), com a resina convencional apresentando maior estabilidade de cor.

2) Os menores e maiores valores de alteração de cor $(\Delta \mathrm{E})$, respectivamente, foram registrados para os grupos controles em água destilada (3 minutos/dia) e hipoclorito de sódio ( $1 \%-8$ horas/dia), sendo este estatisticamente diferente dos demais grupos para ambas as resinas.

3) As alterações de cor $(\Delta E)$ obtidas para as pastilhas efervescentes (Corega Tabs e Bony Plus), hipoclorito de sódio ( $0,5 \%$ e $1 \%$ - 20 minutos) e controle estabelecido (água destilada 20 minutos) foram estatisticamente semelhantes entre si, sendo classificadas como "indiciais", segundo a NBS.

4) As alterações de cor $(\Delta E)$ obtidas para as soluções de 8 horas, foram estatisticamente maiores que para as pastilhas efervescentes (Corega Tabs e Bony Plus) e soluções de hipoclorito de sódio por 20 minutos, sendo classificadas como "leves", de acordo com a NBS. As soluções de hipoclorito de sódio a $1 \%$ apresentaram valores estatisticamente superiores ao grupo controle e ao hipoclorito de sódio a $0,5 \%$. 
Referências Bibliográficas 


\section{REFERÊNCIAS BIBLIOGRÁFICAS*}

1. ABELSON, D.C. Denture plaque and denture cleansers. J Prosthet Dent., St Louis, v. 45, n. 4, p. 376-9, apr. 1981.

2. ABELSON, D.C. Denture plaque and denture cleansers: review of the literature. Gerodontics, Copenhagen, v. 1, n. 5, p. 202-6, oct. 1985.

3. ABERE, D.J. Post-placement care of complete and removable partial dentures. Dent Clin North Am., Philadelphia, v. 23, n. 1, p. 143-51, jan. 1979.

4. ABRAMSON, A.L. Corrosive injury of the esophagus. Result of ingesting some denture cleanser tablets and powder. Arch Otolaryngol., Chicago, v. 104, n. 9, p. 514-6, sep. 1978.

5. ABRAMSON, A.L.; EASON, R.L.; PRYOR, W.H.Jr.; MESSER, E.J. Corrosive injury of the oral cavity and esophagus caused by some denture cleanser powders. Ann Otol Rhinol Laryngol., St. Louis, v. 83, n. 6, p. 714-9, nov./dec. 1974.

6. ABRAMSON, A.L.; EASON, R.L.; PRYOR, W.H.Jr.; MESSER, E.J. Upper digestive tract burns caused by Denalan ${ }^{\circledR}$ denture cleanser powder. Ann Otol Rhinol Laryngol., St. Louis, v. 84, n. 1, p. 102-6, jan./feb. 1975.

7. ANTHONY, D.H.; GIBBONS, P. The nature and behavior of denture cleansers. J Prosthet Dent., St. Louis, v. 8, n. 5, p. 796-810, sep./oct. 1958.

8. ANUSAVICE, K. Phillips Materiais Dentários. 11 a ed. Rio de Janeiro: Elsevier; 2005. Cap. 22, 764p.

\footnotetext{
* De acordo com: ASSOCIAÇÃO BRASILEIRA DE NORMAS TÉCNICAS. NBR 6023: informação e
} documentação - referências: elaboração. Rio de Janeiro, 2002. 24p. 
9. ARAB, J.; NEWTON, J.P.; LLOYD, C.H. The effect of an elevated level of residual monomer on the whitening of a denture base and its physical properties. J Dent., Bristol, v. 17, n. 4, p. 189-94, aug. 1989.

10. ARAB, J.; NEWTON, J.P.; LLOYD, C.H. The importance of water temperature in denture cleaning procedures. J Dent., Bristol, v. 16, n. 6, p. 277-81, dec. 1988.

11. AUGSBURGER, R.H.; ELAHI, J.M. Evaluation of seven proprietary denture cleansers. J Prosthet Dent., St. Louis, v. 47, n. 4, p. 356-9, apr. 1982.

12. AUSTIN, A.T.; BASKER, R.M. Residual monomer levels in denture bases. The effects of varying short curing cycles. Br Dent J., London, v. 153, n. 12, p. 424-6, dec. 1982.

13. BACKENSTOSE, W.M.; WELLS, J.G. Side effects of immersion-type cleansers on the metal components of dentures. J Prosthet Dent., St. Louis, v. 37, n. 6, p. 615-21, jun. 1977.

14. BARNABÉ, W.; de MENDONÇA NETO, T.; PIMENTA, F.C.; PEGORARO, L.F.; SCOLARO, J.M. Efficacy of sodium hypochlorite and coconut soap used as disinfecting agents in the reduction of denture stomatitis, Streptococcus mutans and Candida albicans. $\mathbf{J}$ Oral Rehabil., Oxford, v. 31, n. 5, p. 453-9, may 2004.

15. BASSON, N.J.; QUICK, A.N.; THOMAS, C.J. Household products as sanitising agents in denture cleasing. J Dent Assoc S Afr., Cape Town, v. 47, n. 10, p. 437-9, oct. 1992.

16. BATES, J.F.; SMITH, D.C. Evaluation of indirect resilient liners for dentures: laboratory and clinical tests. J Am Dent Assoc., Chicago, v. 70, p. 344-53, feb. 1965.

17. BAYSAN, A.; WHILEY, R.; WRIGHT, P.S. Use of microwave energy to disinfect a long-term soft lining material contaminated with Candida albicans or Staphylococcus aureus. J Prosthet Dent., St. Louis, v. 79, n. 4, p. 454-8, apr. 1998. 
18. BELL, J.A.; BROCKMANN, S.L.; FEIL, P.; SACKUVICH, D.A. The effectiveness of two disinfectants on denture base acrylic resin with an organic load. J Prosthet Dent., St. Louis, v. 61, n. 5, p. 580-3, may 1989.

19. BUDTZ-JØRGENSEN, E. Materials and methods for cleaning dentures. J Prosthet Dent., St Louis, v. 42, n. 6, p. 619-23, dec. 1979.

20. BUDTZ-JÖRGENSEN, E. Prevention of denture plaque formation by an enzyme denture cleanser. J Biol Buccale, Paris, v. 5, n. 3, p. 239-44, sep. 1977.

21. BUDTZ-JØRGENSEN, E.; BERTRAM, U. Denture stomatitis. I. The etiology in relation to trauma and infection. Acta Odontol Scand., Stockholm, v. 28, n. 1, p. 71-92, mar. 1970.

22. BUDTZ-JØRGENSEN, E.; KNUDSEN A.M. Chlorhexidine gel and Steradent employed in cleaning dentures. Acta Odontol Scand., Stockholm, v. 36, n. 2, p. 83-7, Aug. 1978.

23. BUYUKYILMAZ, S.; RUYTER, I.E. Color stability of denture base polymers. Int J Prosthodont., Lombard, v. 7, n. 4, p. 372-82, jul./aug. 1994.

24. CHAN, E.C.S.; IUGOVAZ, I.; SIBOO, R.; BILYK, M.; BAROLET, R.; AMSEL, R.; WOOLEY, C.; KLITORINOS, A. Comparison of two popular methods for removal and killing of bacteria from dentures. J Can Dent Assoc., Ottawa, v. 57, n. 12, p. 937-9, dec. 1991.

25. CHAU, V.B.; SAUNDERS, T.R.; PIMSLER, M.; ELFRING, D.R. In-depth disinfection of acrylic resins. J Prosthet Dent., St. Louis, v. 74, n. 3, p. 309-13, sep. 1995.

26. COUNCIL ON DENTAL MATERIALS, INSTRUMENTS AND EQUIPMENT. Denture cleansers. J Am Dent Assoc., Chicago, v. 106, n. 1, p. 77-9, jan. 1983.

27. COUNCIL ON DENTAL THERAPEUTICS AND COUNCIL ON PROSTHETIC SERVICES AND DENTAL LABORATORY RELATIONS. Guidelines for infection control 
in the dental office and the commercial dental laboratory. J Am Dent Assoc., Chicago, v. 110, n. 6, p. 969-72, jun. 1985.

28. CRAIG, R.G.; POWERS, J.M. Materiais dentários restauradores. $11^{\mathrm{a}}$ ed. São Paulo: Livraria Editora Santos, 2004. 704p.

29. CRAWFORD, C.A.; NEWTON, J.P.; YEMM, R. Bleached dentures: misuse of a denturecleaning agent. Dent Update, London, v. 14, n. 1, p. 29-32, jan./feb. 1987.

30. CRAWFORD, C.A.; LLOYD, C.H.; NEWTON, J.P.; YEMM, R. Denture bleaching: a laboratory simulation of patients` cleaning procedures. J Dent., Bristol, v. 14, n. 6, p. 258-61, dec. 1986.

31. DE VISSCHERE, L.M.; GROOTEN, L.; THEUNIERS, G.; VANOBBERGEN, J.N. Oral hygiene of elderly people in long-term care institutions - a cross-sectional study. Gerodontology, Mount Desert, v. 23, n. 4, p. 195-204, dec. 2006.

32. DEPAOLA, L.G.; MINAH, G.E.; ELIAS, S.A. Evaluation of agents to reduce microbial growth on dental prostheses of myelosuppressed cancer patients. Clin Prev Dent., Philadelphia, v. 6, n. 2, p. 9-12, mar./apr. 1984.

33. DEVLIN, H.;KAUSHIK, P. The effect of water absorption on acrylic surface properties. J Prosthodont., Philadelphia, v. 14, n. 4, p. 233-8, dec. 2005.

34. DIKBAS, I.; KOKSAL, T.; CALIKKOCAOGLU, S. Investigation of the cleanliness of dentures in a university hospital. Int J Prosthodont., Lombard, v. 19, n. 3, p. 294-8, may/jun. 2006.

35. DILlS, S.S.; OLSHAN, A.M.; GOLDNER, S.; BROGDON, C. Comparison of the antimicrobial capability of an abrasive paste and chemical-soak denture cleaners. J Prosthet Dent., St Louis, v. 60, n. 4, p. 467-70, oct. 1988. 
36. FERRAN, P.; MIGUEL, J.L.; BOUSQUET, A.; DUBOIS, J. Hygiène et prophylaxie en prothèse dentaire complète chez la personne âgée. Inf Dent., Paris, v. 66, n. 15, p. 1509-15, apr. 1984.

37. GARCIA JUNIOR, A. Avaliação da eficácia dos desinfetantes químicos na desinfecção de resina acrílica termopolimerizável. 2002. 101p. + anexos. Dissertação (Mestrado) - Faculdade de Odontologia de Ribeirão Preto, Universidade de São Paulo, Ribeirão Preto, 2002.

38. GHALICHEBAF, M.; GRASER, G.N.; ZANDER, H.A. The efficacy of denture-cleasing agents. J Prosthet Dent., St. Louis, v. 48, n. 5, p. 515-20, nov. 1982.

39. GOLL, G.; SMITH, D.E.; PLEIN, J.B. The effect of denture cleansers on temporary soft liners. J Prosthet Dent., St. Louis, v. 50, n. 4, p. 466-72, oct. 1983.

40. GORNITSKY, M.; PARADIS, I.; LANDAVERDE, G.; MALO, A.M.; VELLY, A.M. A clinical and microbiological evaluation of denture cleansers for geriatric patients in long-term care institutions. J Can Dent Assoc., Ottawa, v. 68, n. 1, p. 39-45, jan. 2002.

41. HOAD-REDDICK, G.; GRANT, A.A.; GRIFFITHS, C.S. Investigation into the cleanliness of dentures in an elderly population. J Prosthet Dent., St Louis, v. 64, n. 1, p. 4852, jul. 1990.

42. HUTCHINS, D.W.; PARKER, W.A. A clinical evaluation of the ability of denture cleaning solutions to remove dental plaque from prosthetic devices. N Y State Dent J., New York, v. 39, n. 6, p. 363-7, jun./jul. 1973.

43. JAGGER, D.C.; AL-AKHAZAMI, L.; HARRISON, A.; REES, J.S. The Effectiveness of seven denture cleansers on tea stain removal from PMMA acrylic resin. Int J Prosthodont., Lombard, v. 15, n. 6, p. 549-52, nov./dec. 2002.

44. JAGGER, D.C.; HARRISON, A. Denture cleansing-the best approach. Br Dent J., London, v. 178, n. 11, p. 413-7, jun. 1995. 
45. JIN, C.; NIKAWA, H.; MAKIHIRA, S.; HAMADA, T.; FURUKAWA, M.; MURATA, $\mathrm{H}$. Changes in surface roughness and colour stability of soft denture lining materials caused by denture cleansers. J Oral Rehabil., Oxford, v. 30, n. 2, p. 125-30, feb. 2003.

46. KEMPLER, D.; MYER, M.; KAHL, E.A.; MARTIN, D.W. The efficacy of sodium hypochlorite as a denture cleanser. Spec Care Dentist., Chicago, v. 2, n. 3, p. 112-5, may/jun. 1982.

47. KENG, S.B.; LIM, M. Denture plaque distribution and the effectiveness of a perboratecontaining denture cleanser. Quintessence Int., Berlin, v. 27, n. 5, p. 341-5, may 1996.

48. KEYF, F.; GÜNGÖR, T. Comparison of effects of bleach and cleansing tablet on reflectance and surface changes of a dental alloy used for removable partial dentures. $\mathbf{J}$ Biomater Appl., Lancaster, v. 18, n. 1, p. 5-14, jul. 2003.

49. KIMURA, H.; TERAOKA, F.; OHNISHI, H.; SAITO, T.; YATO, M. Applications of microwave for dental technique (part 1). Dough-forming and curing of acrylic resins. J Osaka Univ Dent Sch., Osaka, v. 23, p. 43-9, dec. 1983.

50. KIMURA, H.; TERAOKA, F.; SAITO, T. Application of microwave for dental technique (part 2). Adaptability of cured acrylic resins. J Osaka Univ Dent Sch., Osaka, v. 24, p. 21-9, dec. 1984.

51. KULAK, Y.; ARIKAN, A.; ALBAK, S.; OKAR, I.; KAZAZOGLU, E. Scanning electron microscopic examination of different cleaners: surface contaminant removal from dentures. $\mathbf{J}$ Oral Rehabil., Oxford, v. 24, n. 3, p. 209-15, mar. 1997.

52. KULAK-OZKAN, Y.; KAZAZOGLU, E.; ARIKAN, A. Oral hygiene habits, denture cleanliness, presence of yeasts and stomatitis in elderly people. J Oral Rehabil., Oxford, v. 29 , n. 3, p. 300-4, mar. 2002.

53. KWOK, W.M.; RALPH, W.J. The use of chemical disinfectants in dental prosthetics. Aust Dent J., Sydney, v. 29, n. 3, p. 180-3, jun. 1984. 
54. LACERDA, T.S.P. Quais são os recursos utilizados para a limpeza das próteses totais? Rev. Assoc. Paul. Cir. Dent., Araçatuba, v. 52, n. 3, p. 217-8, maio/jun. 1998.

55. LAI, C.P.; TSAI, M.H.; CHEN, M.; CHANG, H.S.; TAY, H.H. Morphology and properties of denture acrylic resins cured by microwave energy and conventional water bath. Dent Mater., Copenhagen, v. 20, n. 2, p. 133-41, feb. 2004.

56. LANGWELL, W.H. The cleansing of artificial dentures. Br Dent J., London, v. 15, n. 11 , p. 337-9, nov. 1955.

57. LIBERMAN, R.; COMBE, E.C.; PIDDOCK, V.; PAWSON, C.; WATTS, D.C. Development and assessment of an objective method of colour change measurement for acrylic denture base resins. J Oral Rehabil., Oxford, v. 22, n. 6, p. 445-9, jun. 1995.

58. MA, T.; JOHNSON, G.H.; GORDON, G.E. Effects of chemical disinfectants on the surface characteristics and color of denture resins. J Prosthet Dent., St. Louis, v. 77, n. 2, p. 197-204, feb. 1997.

59. MACCALLUM, M.; STAFFORD, G.D.; MACCULLOCH, W.T.; COMBE, E.C. Wich cleanser? A report on a survey of denture cleansing routine and the development of a new denture cleanser. Dent Pract Dent Rec., Bristol, v. 19, n. 3, p. 83-9, nov. 1968.

60. MALHEIROS-SEGUNDO, A.L. Solução efervescente para higiene de próteses totais: Influência na sorção de água, solubilidade, dureza e na alteração de cor de reembasadores. 2007. 101p. Dissertação (Mestrado) - Faculdade de Odontologia de Ribeirão Preto, Universidade de São Paulo, Ribeirão Preto, 2007.

61. MANDERSON, R.D.; BROWN, D. A clinical and laboratory investigation of a new denture cleaner. J Dent., Bristol, v. 6, n. 3, p. 222-8, sep. 1978.

62. MARCHINI, L.; TAMASHIRO, E.; NASCIMENTO, D.F.F.; CUNHA, V.P. Selfreported denture hygiene of a sample of edentulous attendees at a University dental clinic and the relationship to the condition of the oral tissues. Gerodontology, Mount Desert, v. 21, n. 4, p. 226-8, dec. 2004. 
63. MARTINS, R.G.; LACERDA, T.S.P.; CARVALHO, J.A.; MAURI, A.C.; ZANETTI, A.L. Métodos para higienização de próteses totais e sua importância: revisão da literatura. Rev Odontol UNICID, São Paulo, v. 16, n. 2, p. 169-76, maio/ago. 2004.

64. MAY, K.B.; SHOTWELL, J.R.; KORAN, A.3rd.; WANG, R.F. Color stability: denture base resins processed with the microwave method. J Prosthet Dent., St. Louis, v. 76, n. 6, p. 581-9, dec. 1996.

65. MCCABE, J.F.; MURRAY, I.D.; KELLY, P.J. The efficacy of denture cleansers. Eur J Prosthodont Restor Dent., Larkfield, v. 3, n. 5, p. 203-7, sep. 1995.

66. MCGOWAN, M.J.; SHIMODA, L.M.; WOOLSEY, G.D. Effects of sodium hypochlorite on denture base metals during immersion for short-term sterilization. J Prosthet Dent., St. Louis, v. 60, n. 2, p. 212-8, aug. 1988.

67. MCNEME, S.J.; VON GONTEN, A.S.; WOOLSEY, G.D. Effects of laboratory disinfecting agents on color stability of denture acrylic resins. J Prosthet Dent., St. Louis, v. 66, n. 1, p. 132-6, jul. 1991.

68. MINAGI, S.; TSUNODA, T.; YOSHIDA, K.; TSURU, H. Objective testing of the efficiency of denture-cleasing agents. J Prosthet Dent., St. Louis, v. 58, n. 5, p. 595-8, nov. 1987.

69. MOLINARI, J.A.; RUNNELS, R.R. Role of disinfectants in infection control. Dent Clin North Am., Philadelphia, v. 35, n. 2, p. 323-37, apr. 1991.

70. MOORE, T.C.; SMITH, D.E.; KENNY, G.E. Sanitization of dentures by several denture hygiene methods. J Prosthet Dent., St. Louis, v. 52, n. 2, p. 158-63, aug. 1984.

71. NAKAMOTO, K.; TAMAMOTO, M.; HAMADA, T. Evaluation of denture cleansers with and without enzymes against Candida albicans. J Prosthet Dent., St. Louis, v. 66, n. 6, p. 792-5, dec. 1991. 
72. NEILL, D.J. A study of materials and methods employed in cleaning dentures. Br Dent J., London, v. 124, n. 3, p. 107-15, feb. 1968.

73. NEPPELENBROEK, K.H.; PAVARINA, A.C.; VERGANI, C.E.; GIAMPAOLO, E.T. Hardness of heat-polymerized acrylic resins after disinfection and long-term water immersion. J Prosthet Dent., St. Louis, v. 93, n. 2, p. 171-6, feb. 2005.

74. NICHOLSON, R.J.; STARK, M.M.; SCOTT, H.E.Jr. Calculus and stain removal from acrylic resin dentures. J Prosthet Dent., St Louis, v. 20, n. 4, p. 326-9, oct. 1968.

75. NIKAWA, H.; HAMADA, T.; YAMAMOTO, T. Denture plaque - past and recent concerns. J Dent., Bristol, v. 26, n. 4, p. 299-304, may 1998.

76. NIKAWA, H.; HAMADA, T.; YAMASHIRO, H.; KUMAGAI, H. A review of in vitro and in vivo methods to evaluate the efficacy of denture cleansers. Int J Prosthodont., Lombard, v. 12, n. 2, p. 153-9, mar./apr. 1999.

77. NIKAWA, H.; JIN, C.; MAKIHIRA, S.; EGUSA, H.; HAMADA, T.; KUMAGAI, H. Biofilm formation of Candida albicans on the surfaces of deteriorated soft denture lining materials caused by denture cleansers in vitro. J Oral Rehabil., Oxford, v. 30, n. 3, p. 243-50, mar. 2003.

78. PALENIK, C.J.; MILLER, C.H. In vitro testing of three denture-cleaning systems. J Prosthet Dent., St. Louis, v. 51, n. 6, p. 751-4, jun. 1984.

79. PARANHOS, H.F.O.; MALACHIAS, A.; PARDINI, L.C. Materiais para limpeza de dentaduras: Revisão da literatura. Rev Fac Odontol Lins, Lins, v. 4, n. 2, p. 19-24, jul./dez. 1991.

80. PARANHOS, H.F.O.; SILVA-LOVATO, C.H.; SOUZA, R.F.; CRUZ, P.C.; FREITAS, K.M.; PERACINI, A. Effects of mechanical and chemical methods on denture biofilm accumulation. J Oral Rehabil., Oxford, v. 34, n. 8, p. 606-12, aug. 2007. 
81. PAVARINA, A.C.; MACHADO, A.L.; GIAMPAOLO, E.T.; VERGANI, C.E. Effects of chemical disinfectants on the transverse strength of denture base acrylic resins. J Oral Rehabil., Oxford, v. 30, n. 11, p. 1085-9, nov. 2003(a).

82. PAVARINA, A.C.; PIZZOLITTO, A.C.; MACHADO, A.L.; VERGANI, C.E; GIAMPAOLO, E.T. An infection control protocol: effectiveness of immersion solutions to reduce the microbial growth on dental prostheses. J Oral Rehabil., Oxford, v. 30, n. 5, p. 532-6, may 2003(b).

83. PAZZINI, N.A.; MUTTI, N.M.; PAZZINI, L.I. Higienizadores para dentaduras artificiais. Rev Gaucha Odont., Porto Alegre, v. 20, n. 4, p. 282-6, out./dez. 1972.

84. POLYZOIS, G.L. Denture cleasing habits. A survey. Aust Dent J., Sydney, v. 28, n. 3, p. 171-3, jun. 1983.

85. POLYZOIS, G.L.; YANNIKAKIS, S.A.; ZISSIS, A.J.; DEMETRIOU, P.P. Color changes of denture base materials after disinfection and sterilization immersion. Int $\mathbf{J}$ Prosthodont., Lombard, v. 10, n. 1, p. 83-9, jan./feb. 1997.

86. POWERS, J.M.; LEPEAK, P.J. Parameters that affect the color of denture resins. J Dent Res., Chicago, v. 56, n. 11, p. 1331-5, nov. 1977.

87. PURNAVEJA, S.; FLETCHER, A.M.; RITCHIE, G.M.; AMIN, W.M.; MORADIANS, S.; DODD, A.W. Colour stability of two self curing denture base materials. Biomaterials, Guilford, v. 3, n. 4, p. 249-50, oct. 1982.

88. RAAB, F.J.; TAYLOR, C.A.; BUCHER, J.A.; MANN, B.L. Scanning electron microscopic examination of ultrasonic and effervescent methods of surface contaminant removal from complete dentures. J Prosthet Dent., St Louis, v. 65, n. 2, p. 255-8, feb. 1991.

89. ROBINSON, J.G.; MCCABE, J.F.; STORER, R. Denture bases: the effects of various treatments on clarity, strengh and structure. J Dent., Bristol, v. 15, n. 4, p. 159-65, aug. 1987. 
90. ROBINSON, J.G.; MCCABE, J.F.; STORER, R. The whitening of acrylic dentures: the role of denture cleansers. Br Dent J., London, v. 159, n. 8, p. 247-50, oct. 1985.

91. RUDD, R.W.; SENIA, E.S.; MCCLESKEY, F.K.; ADAMS, E.D.Jr. Sterilization of complete dentures with sodium hypochlorite. J Prosthet Dent., St. Louis, v. 51, n. 3, p. 31821, mar. 1984.

92. RUTALA, W.A.; WEBER, D.J. Uses of inorganic hypochlorite (bleach) in health- care facilities. Clin Microbiol Rev., Washington, v. 10, n. 4, p. 597-610, oct. 1997.

93. SATO, S.; CAVALCANTE, M.R.S.; ORSI, I.A.; PARANHOS, H.F.O.; ZANIQUELLI, $O$. Assessment of flexural strenght and color alteration of heat-polymerized acrylic resins after simulated use of denture cleansers. Braz Dent J., Ribeirão Preto, v. 16, n. 2, p. 124-8, may/aug. 2005.

94. SCHOU, L.; WIGHT, C.; CUMMING, C. Oral hygiene habits, denture plaque, presence of yeasts and stomatitis in institutionalised elderly in Lothian, Scotland. Community Dent Oral Epidemiol., Copenhagen, v. 15, n. 2, p. 85-9, apr. 1987.

95. SESMA, N.; TAKADA, K.S.; LAGANÁ, D.C.; JAEGER, R.G.; AZAMBUJA Jr N. Eficiência de métodos caseiros de higienização e limpeza de próteses parciais removíveis. Rev. Assoc. Paul. Cir. Dent., Araçatuba, v. 53, n. 6, p. 463-8, nov./dez. 1999.

96. SHANNON, I.L.; STARCKE, E.N. Higher performance denture cleansers. N Y J Dent., Brooklyn, v. 48, n. 8, p. 246-50, oct. 1978.

97. SHAY, K. Denture hygiene: a review and update. J Contemp Dent Pract., Cincinnati, v. 1, n. 2, p. 28-41, feb. 2000.

98. SHEEN, S.R.; HARRISON, A. Assessment of plaque prevention on dentures using an experimental cleanser. J Prosthet Dent., St Louis, v. 84, n. 6, p. 594-601, dec. 2000. 
99. SMITH, D.C. Denture Cleansers. Dent. Pract. Dent Res., Bristol, v. 12, n. 3, p. 93-4, nov. 1961.

100. SMITH, D.C. The cleansing of dentures. Dent Pract Dent Rec., Bristol, v. 17, n. 2, p. 39-43, oct. 1966.

101. SUMI, Y.; MIURA, H.; SUNAKAWA, M.; MICHIWAKI, Y.; SAKAGAMI, N. Colonization of denture plaque by respiratory pathogens in dependent elderly. Gerodontology, Mount Desert, v. 19, n. 1, p. 25-9, jul. 2002.

102. TAN, H.; WOO, A.; KIM, S.; LAMOUREUX, M.; GRACE, M. Effect of denture cleansers, surface finish, and temperature on Molloplast B resilient liner color, hardness, and texture. J Prosthodont., Philadelphia, v. 9, n. 3, p. 148-55, sep. 2000.

103. TARBET, W.J.; AXELROD, S.; MINKOFF, S.; FRATARCANGELO, P.A. Denture cleasing: a comparison of two methods. J Prosthet Dent., St. Louis, v. 51, n. 3, p. 322-5, mar. 1984.

104. TAYLOR, V.E.; JORDAN, M.F. Denture corrosion. Report of a case. Br Dent J., London, v. 122, n. 9, p. 399, may 1967.

105. ÜNLÜ, A.; ALTAY, O.T.; SAHMALI, S. The role of denture cleansers on the whitening of acrylic resins. Int J Prosthodont., Lombard, v. 9, n. 3, p. 266-70, may/jun. 1996.

106. WAGNER, A.G. Maintenance of the partially edentulous mouth and care of the denture. Dent Clin North Am., Philadelphia, v. 17, n. 4, p. 755-68, oct. 1973.

107. WALKER, D.M.; STAFFORD, G.D.; HUGGETT, R.; NEWCOMBE, R.G. The treatment of denture-induced stomatitis. Evaluation of two agents. Br Dent J., London, v. 151, n. 12, p. 416-9, dec. 1981. 
108. WATKINSON, A.C.; MCCREIGHT, M.C.; WORNOCK, D.W. Prevalence and persistence of different strains of Candida albicans in treatment of denture stomatitis. $\mathbf{J}$ Prosthet Dent., St. Louis, v. 53, n. 3, p. 365-6, mar. 1985.

109. WEBB, B.C.; THOMAS, C.J.; HARTY, D.W.S.; WILLCOX, M.D.P. Effectiveness of two methods of denture sterilization. J Oral Rehabil., Oxford, v. 25, n. 6, p. 416-23, jun. 1998.

110. WEBB, B.C.; THOMAS, C.J.; WHITTLE, T. A 2-year study of Candida -associated denture stomatitis treatment in aged care subjects. Gerodontology, Mount Desert, v. 22, n. 3, p. 168-76, sep. 2005.

111. WEBB, B.C.; WILlCOX, M. D. P.; THOMAS, C.J.; HARTY, D.W.S.; KNOX, K.W.; The effect of sodium hypochlorite on potential pathogenic traits of Candida albicans and other Candida species. Oral Microbiol Immunol., Copenhagen, v. 10, n. 6, p. 334-41, dec. 1995.

112. YILMAZ, H.; AYDIN, C.; BAL B.T.; OCAK, F. Effects of different disinfectants on physical properties of four temporary soft denture-liner materials. Quintessence Int., Berlin, v. 35, n. 10, p. 826-34, nov./dec. 2004.

113. YILMAZ, H.; AYDIN, C.; BAL B.T.; OZCELIK B. Effects of disinfectants on resilient denture-lining materials contaminated with Staphylococcus aureus, Streptococcus sobrinus, and Candida albicans. Quintessence Int., Berlin, v. 36, n. 5, p. 373-81, may 2005.

114. ZARB, G.A.; BOLENDER, C.L.; CARLSSON, G.E. Boucher's Prosthodontic Treatment for Edentulous Patients. $11^{\text {th }}$. Ed. Mosby, St. Louis, 2000. 558p. 
Apêndices 
Tabela A1 - Dados dos parâmetros L*, a*, b* para pastilha Bony Plus.

\begin{tabular}{|c|c|c|c|c|c|c|c|c|c|c|c|c|}
\hline \multirow{3}{*}{$\begin{array}{l}\text { Resinas } \\
\text { Acrílicas }\end{array}$} & \multicolumn{12}{|c|}{ Tempo (3 minutos) } \\
\hline & \multicolumn{6}{|c|}{ Água } & \multicolumn{6}{|c|}{ Bony Plus } \\
\hline & $\mathbf{L}_{\mathbf{i}}$ & $\mathbf{L}_{\mathbf{f}}$ & $\overline{\mathbf{a}_{\mathbf{i}}}$ & $a_{f}$ & $\mathbf{b}_{\mathbf{i}}$ & $\mathbf{b}_{\mathrm{f}}$ & $\mathbf{L}_{\mathbf{i}}$ & $\mathbf{L}_{\mathbf{f}}$ & $\mathbf{a}_{\mathbf{i}}$ & $a_{f}$ & $\mathbf{b}_{\mathbf{i}}$ & $\mathbf{b}_{\mathrm{f}}$ \\
\hline \multirow{10}{*}{$\begin{array}{c}\text { Onda } \\
\text { Cryl }\end{array}$} & 49,70 & 49,54 & 23,07 & 22,9 & 11,87 & 11,72 & 50,79 & 50,27 & 22,79 & 22,97 & 11,40 & 12,19 \\
\hline & 49,83 & 49,71 & 23,50 & 23,25 & 12,23 & 12,16 & 49,79 & 49,79 & 22,80 & 22,76 & 12,03 & 12,12 \\
\hline & 49,59 & 49,52 & 23,44 & 23,54 & 12,04 & 12 & 50,72 & 50,54 & 23,36 & 23,42 & 12,17 & 12,31 \\
\hline & 49,92 & 49,87 & 23,14 & 23,22 & 12,08 & 12,22 & 50,62 & 50,39 & 22,81 & 22,84 & 11,53 & 12,15 \\
\hline & 49,49 & 49,34 & 23,56 & 23,52 & 11,94 & 12,18 & 49,84 & 49,69 & 23,39 & 23,47 & 11,83 & 11,92 \\
\hline & 50,29 & 50,18 & 23,39 & 23,55 & 12,59 & 12,8 & 50,08 & 49,94 & 23,22 & 23,29 & 10,88 & 10,72 \\
\hline & 50,64 & 50,55 & 23,32 & 23,42 & 12,54 & 12,55 & 50,03 & 49,95 & 23,70 & 23,67 & 12,41 & 12,42 \\
\hline & 49,17 & 49,15 & 23,50 & 23,4 & 11,97 & 12,07 & 51,20 & 50,7 & 22,18 & 21,94 & 11,65 & 12,33 \\
\hline & 50,28 & 50,21 & 23,53 & 23,48 & 12,09 & 12,33 & 50,72 & 50,54 & 23,00 & 22,62 & 11,83 & 12,29 \\
\hline & 49,53 & 49,4 & 23,04 & 23,13 & 11,56 & 11,88 & 50,52 & 50,13 & 22,98 & 23,2 & 11,83 & 11,9 \\
\hline \multirow{10}{*}{$\begin{array}{c}\text { Lucitone } \\
\mathbf{5 5 0}\end{array}$} & 48,87 & 48,74 & 23,89 & 23,99 & 10,04 & 10,07 & 49,34 & 49,25 & 24,15 & 24,26 & 10,13 & 10,42 \\
\hline & 49,25 & 49,23 & 23,87 & 24,11 & 10,57 & 10,74 & 48,62 & 48,47 & 23,73 & 23,96 & 10,38 & 10,58 \\
\hline & 49,09 & 49,04 & 24,38 & 24,52 & 10,23 & 10,4 & 49,48 & 49,31 & 23,98 & 24,05 & 9,73 & 10,22 \\
\hline & 48,91 & 48,79 & 23,61 & 23,85 & 9,99 & 10,16 & 50,40 & 49,93 & 24,34 & 24,72 & 9,53 & 9,91 \\
\hline & 49,09 & 49,05 & 23,69 & 23,55 & 10,01 & 10,34 & 49,60 & 49,33 & 24,18 & 24,23 & 10,07 & 10,32 \\
\hline & 49,22 & 49,3 & 23,89 & 23,92 & 9,79 & 9,75 & 49,69 & 49,61 & 24,43 & 24,38 & 10,51 & 10,34 \\
\hline & 48,93 & 48,79 & 23,46 & 23,61 & 10,34 & 10,51 & 50,66 & 50,17 & 24,13 & 24,33 & 10,11 & 10,45 \\
\hline & 49,57 & 49,6 & 23,78 & 24,1 & 9,94 & 10,05 & 49,96 & 49,55 & 24,30 & 24,8 & 10,11 & 10,26 \\
\hline & 49,71 & 49,6 & 23,54 & 23,88 & 10,41 & 10,56 & 49,30 & 49,21 & 24,61 & 24,65 & 10,40 & 10,48 \\
\hline & 49,77 & 49,76 & 23,62 & 23,68 & 9,98 & 10,35 & 50,18 & 50,1 & 22,59 & 22,43 & 10,95 & 11,56 \\
\hline
\end{tabular}


Tabela A2- Dados dos parâmetros L*, a*, b* para pastilha Corega Tabs.

\begin{tabular}{|c|c|c|c|c|c|c|c|c|c|c|c|c|}
\hline \multirow{3}{*}{$\begin{array}{l}\text { Resinas } \\
\text { Acrílicas }\end{array}$} & \multicolumn{12}{|c|}{ Tempo (5 minutos) } \\
\hline & \multicolumn{6}{|c|}{ Água } & \multicolumn{6}{|c|}{ Corega Tabs } \\
\hline & $\overline{\mathbf{L}_{\mathbf{i}}}$ & $\mathbf{L}_{\mathbf{f}}$ & $\mathbf{a}_{\mathbf{i}}$ & $\mathbf{a}_{\mathbf{f}}$ & $\mathbf{b}_{\mathbf{i}}$ & $\mathbf{b}_{\mathbf{f}}$ & $\mathbf{L}_{\mathbf{i}}$ & $\mathbf{L}_{\mathbf{f}}$ & $\mathbf{a}_{\mathbf{i}}$ & $\mathbf{a}_{\mathrm{f}}$ & $\mathbf{b}_{\mathbf{i}}$ & $\mathbf{b}_{\mathbf{f}}$ \\
\hline \multirow{10}{*}{$\begin{array}{c}\text { Onda } \\
\text { Cryl }\end{array}$} & 51,05 & 50,72 & 23,12 & 22,94 & 9,58 & 10,96 & 49,60 & 49,2 & 24,60 & 24,3 & 12,20 & 12,12 \\
\hline & 51,33 & 51,35 & 20,80 & 20,22 & 13,10 & 13,65 & 50,39 & 50,17 & 23,23 & 23,13 & 12,01 & 11,64 \\
\hline & 51,08 & 50,9 & 24,01 & 23,95 & 11,52 & 11,35 & 49,77 & 49,69 & 23,72 & 23,5 & 12,22 & 12,21 \\
\hline & 51,02 & 50,81 & 23,06 & 22,72 & 11,71 & 11,67 & 49,29 & 49,02 & 23,86 & 23,85 & 12,23 & 11,83 \\
\hline & 51,03 & 50,97 & 22,59 & 21,86 & 12,54 & 12,94 & 50,32 & 49,99 & 23,93 & 23,89 & 11,96 & 11,93 \\
\hline & 50,82 & 50,56 & 22,98 & 23,1 & 11,95 & 11,63 & 49,72 & 49,38 & 23,94 & 23,94 & 12,39 & 11,94 \\
\hline & 51,16 & 50,92 & 22,65 & 22,66 & 11,70 & 11,13 & 49,89 & 49,64 & 23,95 & 23,65 & 12,41 & 12,7 \\
\hline & 51,38 & 50,89 & 23,44 & 23,31 & 11,60 & 11,97 & 50,53 & 50,42 & 24,24 & 24 & 12,11 & 12,05 \\
\hline & 51,91 & 51,82 & 22,16 & 21,41 & 11,96 & 12,46 & 50,00 & 49,64 & 24,01 & 23,96 & 12,08 & 12,18 \\
\hline & 52,04 & 51,93 & 21,22 & 21,14 & 12,23 & 11,93 & 49,34 & 49,05 & 24,18 & 24,14 & 12,65 & 12,23 \\
\hline \multirow{10}{*}{$\begin{array}{c}\text { Lucitone } \\
\mathbf{5 5 0}\end{array}$} & 49,38 & 49,02 & 24,27 & 23,97 & 10,55 & 10,73 & 49,16 & 49 & 24,46 & 24,3 & 10,78 & 10,54 \\
\hline & 50,07 & 49,84 & 24,62 & 24,43 & 10,48 & 10,4 & 50,03 & 49,84 & 25,01 & 24,83 & 11,13 & 11,01 \\
\hline & 48,94 & 48,8 & 24,14 & 24,01 & 10,32 & 10,22 & 49,07 & 49,15 & 24,01 & 23,61 & 10,70 & 10,45 \\
\hline & 48,72 & 48,44 & 24,04 & 23,91 & 10,34 & 10,21 & 49,09 & 49,07 & 24,39 & 24,03 & 10,69 & 10,43 \\
\hline & 50,30 & 49,8 & 24,66 & 24,38 & 11,12 & 10,72 & 49,29 & 49,14 & 24,25 & 23,93 & 10,75 & 10,33 \\
\hline & 49,69 & 49,31 & 24,91 & 24,69 & 11,53 & 11,3 & 49,50 & 49,32 & 24,50 & 24,31 & 10,91 & 10,63 \\
\hline & 49,52 & 48,75 & 24,00 & 24,44 & 10,94 & 10,78 & 49,19 & 49,08 & 24,25 & 23,66 & 10,54 & 10,21 \\
\hline & 48,87 & 48,71 & 24,20 & 23,99 & 10,38 & 10,1 & 49,77 & 49,56 & 24,53 & 24,09 & 10,95 & 10,9 \\
\hline & 49,29 & 48,95 & 24,74 & 24,65 & 10,78 & 10,22 & 48,95 & 48,69 & 24,54 & 24,27 & 10,69 & 10,43 \\
\hline & 50,08 & 49,88 & 24,52 & 24,2 & 10,69 & 10,83 & 49,90 & 49,58 & 24,90 & 24,43 & 11,31 & 11,01 \\
\hline
\end{tabular}


Tabela A3- Dados dos parâmetros L*, a*, b* para Hipoclorito de Sódio por 20 minutos.

\begin{tabular}{|c|c|c|c|c|c|c|c|c|c|c|c|c|c|c|c|c|c|c|}
\hline \multirow{3}{*}{$\begin{array}{c}\text { Resinas } \\
\text { Acrílicas }\end{array}$} & \multicolumn{18}{|c|}{ Tempo (20 minutos) } \\
\hline & \multicolumn{6}{|c|}{ Água } & \multicolumn{6}{|c|}{ Hipoclorito de sódio $0,5 \%$} & \multicolumn{6}{|c|}{ Hipoclorito de sódio $1,0 \%$} \\
\hline & $\mathbf{L}_{\mathbf{i}}$ & $\mathbf{L}_{\mathbf{f}}$ & $\mathbf{a}_{\mathbf{i}}$ & $\mathbf{a}_{\mathbf{f}}$ & $\mathbf{b}_{\mathbf{i}}$ & $\mathbf{b}_{\mathbf{f}}$ & $\mathbf{L}_{\mathbf{i}}$ & $\mathbf{L}_{\mathbf{f}}$ & $\mathbf{a}_{\mathbf{i}}$ & $\mathbf{a}_{\mathrm{f}}$ & $\mathbf{b}_{\mathbf{i}}$ & $\mathbf{b}_{\mathrm{f}}$ & $\mathbf{L}_{\mathbf{i}}$ & $\mathbf{L}_{\mathbf{f}}$ & $\mathbf{a}_{\mathbf{i}}$ & $\mathbf{a}_{\mathbf{f}}$ & $\mathbf{b}_{\mathbf{i}}$ & $\mathbf{b}_{\mathbf{f}}$ \\
\hline \multirow{10}{*}{$\begin{array}{c}\text { Onda } \\
\text { Cryl }\end{array}$} & 49,13 & 48,82 & 24,02 & 23,87 & 12,31 & 12,27 & 49,02 & 48,74 & 23,89 & 23,88 & 12,76 & 12,73 & 48,65 & 48,54 & 23,93 & 23,66 & 11,95 & 12,2 \\
\hline & 49,32 & 49,21 & 23,71 & 23,68 & 12,25 & & 48,39 & & 24,04 & & 12,32 & 12,36 & 9,42 & 49,15 & 23,06 & 22,77 & 11,68 & \\
\hline & 48,95 & 48,58 & 25,08 & 25,07 & 12,65 & 12,6 & 48,11 & 47 & & & 11,77 & & & & & 19 &, 49 & 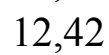 \\
\hline & 49,13 & 48,82 & 24,10 & 24,21 & 11,82 & 12,18 & 48,90 & 48,71 & 23,70 & 23,67 & 12,76 & 12,55 & 47,68 & 47,59 & 25,38 & 25,13 & 12,38 & 12,23 \\
\hline & 49,68 & 49,33 & 23,99 & 24,07 & 12,62 & 12,68 & 49,44 & 49,3 & 23,59 & 23,18 & 12,70 & 12,61 & 49,25 & 49,17 & 24,62 & 24,42 & 13,12 & 12,99 \\
\hline & 49,38 & 49,24 & 24,24 & 24,21 & 12,69 & 12,71 & 48,54 & 48,26 & & & 11,96 & 12,03 & & & & , 1 & 05 &, 94 \\
\hline & 49,45 & 49,23 & 23,02 & 23,08 & 12,01 & 11,72 & 49,64 & 49,48 & 23,34 & & 12,43 & 12,43 & 49,50 & 49,56 & 24,28 & & 12,57 & 12,65 \\
\hline & 49,35 & 49,13 & 23,52 & 23,57 & 12,24 & 12,05 & 49,52 & 49,5 & 23,67 & 23,36 & 12,89 & 12,81 & 48,93 & 48,95 & 24,04 & 23 & 12,44 & 12,41 \\
\hline & 48,45 & 48,16 & 24,19 & 24,19 & 11,93 & 12,1 & 48,63 & 48,61 & 24 & & 13,28 & 13,05 & 49,07 & 49,04 & & & 13,16 & 13,06 \\
\hline & 48,89 & 48,66 & 23,72 & 23,58 & 12,39 & 12,27 & 48,64 & 48,54 & 23 & & 12,39 & 12,22 & 49,75 & 49,3 & & & 11,81 & 12,18 \\
\hline \multirow{10}{*}{$\begin{array}{c}\text { Lucitone } \\
\mathbf{5 5 0}\end{array}$} & 49,05 & 48,95 & 24,10 & 23,98 & 10,36 & 10,26 & 48,45 & 48,21 & 23 & 23 & 10,03 & & 48,70 & 48,37 & & 24 & 10,28 & 9,98 \\
\hline & & & & & & & & & & & & & & & & & & \\
\hline & 48,57 & 48,28 & 24,91 & 24,64 & 10,26 & 10,12 & 48,74 & 48,63 & 24,21 & 23,91 & 9,95 & 9,94 & 49,05 & 48,9 & 24,24 & 24,05 & 10,40 & 10,26 \\
\hline & & 48,69 & 24,29 & 24,04 & 10,68 & 10,56 & 48,86 & 48,62 & 24,56 & 24,28 & 10,24 & 10,35 & 48,83 & 48,55 & 24,40 & 24,14 & 10,56 & 10,32 \\
\hline & 49,49 & 49,33 & 24,57 & 24,47 & 10,95 & 10,74 & 48,39 & 48,24 & 24,31 & 24,15 & 10,17 & 9,91 & 49,49 & 49,04 & 24,77 & 24,54 & 10,95 & 10,54 \\
\hline & 49,01 & 48,91 & 24,46 & 24,25 & 9,98 & 9,99 & 48,86 & 48,87 & 24,67 & 24,31 & 10,44 & 10,34 & 48,68 & 48,55 & 24,37 & 24,04 & 10,55 & 10,23 \\
\hline & 48,68 & 48,47 & 24,83 & 24,64 & 10,11 & 10,2 & 49,04 & 48,69 & 24,53 & 24,18 & 10,35 & 10,21 & 49,00 & 48,55 & 23,92 & 23,84 & 9,98 & 10,06 \\
\hline & 49,31 & 49,11 & 24,50 & 24,72 & 10,85 & 10,58 & 48,45 & 48,3 & 24,91 & 24,62 & 10,73 & 10,49 & 48,91 & 48,58 & 24,26 & 23,93 & 10,26 & 10,01 \\
\hline & 49,00 & 48,79 & 24,23 & 24,14 & 10,54 & 10,44 & 48,47 & 48,3 & 24,58 & 24,3 & 10,37 & 10,21 & 48,49 & 48,38 & 24,44 & 24,1 & 10,20 & 9,97 \\
\hline & 49,09 & 48,86 & 24,67 & 24,5 & 11,04 & 10,91 & 48,43 & 48,26 & 24,38 & 24,24 & 10,19 & 9,73 & 48,89 & 48,46 & 24,59 & 24,58 & 10,27 & 10,02 \\
\hline
\end{tabular}


Tabela A4- Dados dos parâmetros L*, a*, b* para Hipoclorito de Sódio por 8 horas.

\begin{tabular}{|c|c|c|c|c|c|c|c|c|c|c|c|c|c|c|c|c|c|c|}
\hline \multirow{3}{*}{$\begin{array}{l}\text { Resinas } \\
\text { Acrílicas }\end{array}$} & \multicolumn{18}{|c|}{ Tempo (8 horas) } \\
\hline & \multicolumn{6}{|c|}{ Água } & \multicolumn{6}{|c|}{ Hipoclorito de sódio $\mathbf{0 , 5 \%}$} & \multicolumn{6}{|c|}{ Hipoclorito de sódio $1,0 \%$} \\
\hline & $\mathbf{L}_{\mathbf{i}}$ & $\mathbf{L}_{\mathbf{f}}$ & $\mathbf{a}_{\mathbf{i}}$ & $a_{\mathbf{f}}$ & $\mathbf{b}_{\mathbf{i}}$ & $\mathbf{b}_{\mathbf{f}}$ & $\mathbf{L}_{\mathbf{i}}$ & $\mathbf{L}_{\mathbf{f}}$ & $\mathbf{a}_{\mathbf{i}}$ & $\mathbf{a}_{\mathbf{f}}$ & $\mathbf{b}_{\mathbf{i}}$ & $\mathbf{b}_{\mathrm{f}}$ & $\mathbf{L}_{\mathbf{i}}$ & $\mathbf{L}_{\mathbf{f}}$ & $\mathbf{a}_{\mathbf{i}}$ & $a_{f}$ & $\mathbf{b}_{\mathbf{i}}$ & $\mathbf{b}_{\mathbf{f}}$ \\
\hline \multirow{10}{*}{$\begin{array}{c}\text { Onda } \\
\text { Cryl }\end{array}$} & 9,21 & 48,83 & 23,82 & 23,48 & 12,79 & 12,05 & 48,94 & 48,86 & 23,59 & 22,87 & 12,25 & 11,82 & 49,18 & 49,02 & 23,92 & 22,95 & 12,38 & 11,99 \\
\hline & 49,00 & 49,14 & 24,10 & 23,4 & 12,12 & 12,04 & 49,50 & 49,39 & 24,11 & 23,36 & 12,63 & 12,37 & 49,56 & 49,44 & 23,82 & 22,92 & 12,95 & 12,34 \\
\hline & 49,36 & 48,83 & 24,07 & 23,46 & 12,72 & 12,43 & 50,46 & 50,15 & 23,35 & 22,64 & 12,15 & 11,83 & 49,28 & 48,97 & 23,57 & 22,65 & 12,09 & 11,72 \\
\hline & 49,32 & 49,05 & 24,67 & 24,13 & 13,10 & 12,65 & 49,23 & 49,06 & & & 12,40 & 12,29 & 48,99 & 48,8 &, 23 & & 11,97 & 11,4 \\
\hline & 49,58 & 49,36 & 23,53 & 22,91 & 12,86 & 12,67 & 49,21 & 49,24 & 23,32 & 22,57 & 12,12 & 11,84 & 49,18 & 49,08 & 24,38 & & 12,94 & 12,2 \\
\hline & 50,36 & 49,96 & 23,78 & 23 & 12,51 & 12,09 & 50,25 & 50,25 & 23,47 & 22,75 & 12,38 & 12,03 & 49,17 & 49,05 & 23,38 & 22,45 & 11,92 & 11,59 \\
\hline & 50,54 & 49,85 & 23,63 & 23,22 & 12,58 & 12,49 & 49,24 & 49 & 23,55 & 22,89 & 11,91 & 11,74 & 49,71 & 49,48 & 4 & 22 & 12,39 & 11,58 \\
\hline & 50,62 & 50,42 & 22,14 & 22,05 & 12,42 & 11,74 & 49,41 & 49,68 & 23,26 & 22,49 & 12,44 & 12,1 & 49,17 & 48,93 & 4 & & 12,42 & 11,96 \\
\hline & 51,10 & 50,76 & 23,52 & 23,21 & 12,36 & 11,87 & 49,52 & 49,32 & & 22,26 & 12,45 & 12,02 & 48,88 & 48,67 & & & 12,39 & \\
\hline & & 50,11 & & 22,63 & & & & 48,78 & & & & & & & & & & \\
\hline \multirow{10}{*}{$\begin{array}{c}\text { Lucitone } \\
\mathbf{5 5 0}\end{array}$} & 48,97 & 49 & 25,08 & 24,47 & 10,90 & 10,72 & 48,91 & 49,02 & 24,61 & 24,01 & 10,82 & 10,53 & 48,94 & 49,01 & 24,58 & 23,85 & 10,83 & 10,45 \\
\hline & 49,05 & 49,06 & 24,83 & 24,46 & 10,83 & 10,4 & 49,32 & 49,24 & 24,81 & 24,36 & 10,73 & 10,46 & 48,66 & 48,71 & 24,84 & & 10,73 & 10,26 \\
\hline & & 48,62 & 24,45 & 23,82 & & & & 48,79 & & & & & & & & & & 10,37 \\
\hline & 49,19 & 49,16 & 25,16 & 24,51 & 10,96 & 10,93 & 48,63 & 48,78 & 25,11 & 24,53 & 10,69 & 10,53 & 48,80 & 48,74 & 25,07 & 24,42 & 10,58 & 10,19 \\
\hline & 48,66 & 48,58 & 24,80 & 24,32 & 10,63 & 10,29 & 48,76 & 48,86 & 24,79 & 24,36 & 10,74 & 10,5 & 49,02 & 48,98 & 24,72 & 24,08 & 10,89 & 10,51 \\
\hline & 49,00 & 49,01 & 24,73 & 24,32 & 10,52 & 10,19 & 48,94 & 48,98 & 25,06 & 24,55 & 11,04 & 10,75 & 49,06 & 49,1 & 24,65 & 24,11 & 10,69 & 10,33 \\
\hline & 49,16 & 49,02 & 24,45 & 24,11 & 10,97 & 10,49 & 49,22 & 49,16 & 25,07 & 24,72 & 11,21 & 10,86 & 48,74 & 48,77 & 24,81 & 24,19 & 10,78 & 10,45 \\
\hline & 48,98 & 48,92 & 25,08 & 24,34 & 10,19 & 10,46 & 48,77 & 48,76 & 25,45 & 24,96 & 10,72 & 10,51 & 48,64 & 48,58 & 24,69 & 23,95 & 10,75 & 10,24 \\
\hline & 48,92 & 48,87 & 25,61 & 25,01 & 11,28 & 10,8 & 48,90 & 48,97 & 25,81 & 25,37 & 11,11 & 10,9 & 48,81 & 48,69 & 24,71 & 24,12 & 10,70 & 10,4 \\
\hline & 48,47 & 48,5 & 25,21 & 24,8 & 10,68 & 10,55 & 49,29 & 49,23 & 24,66 & 24,33 & 10,99 & 10,71 & 48,96 & 48,94 & 24,52 & 24,27 & 10,82 & 10,06 \\
\hline
\end{tabular}


Tabela A5- Dados de alteração de cor para Pastilha Bony Plus.

\begin{tabular}{|c|c|c|c|c|c|c|c|c|}
\hline \multirow{3}{*}{$\begin{array}{r}\text { Resinas } \\
\text { Acrílicas }\end{array}$} & \multicolumn{8}{|c|}{ Tempo (3 minutos) } \\
\hline & \multicolumn{4}{|c|}{ Água } & \multicolumn{4}{|c|}{ Bony Plus } \\
\hline & $\Delta \mathbf{L}$ & $\Delta \mathbf{a}$ & $\Delta \mathbf{b}$ & $\Delta \mathbf{E}$ & $\Delta \mathbf{L}$ & $\Delta \mathbf{a}$ & $\Delta \mathbf{b}$ & $\Delta \mathbf{E}$ \\
\hline \multirow{10}{*}{$\begin{array}{l}\text { Onda } \\
\text { Cryl }\end{array}$} & $-0,16$ & $-0,16$ & $-0,15$ & 0,27 & $-0,51$ & 0,17 & 0,78 & 0,94 \\
\hline & $-0,12$ & $-0,25$ & $-0,06$ & 0,28 & 0 & $-0,03$ & 0,08 & 0,08 \\
\hline & $-0,07$ & 0,09 & $-0,04$ & 0,12 & $-0,18$ & 0,06 & 0,14 & 0,23 \\
\hline & $-0,04$ & 0,08 & 0,13 & 0,15 & $-0,23$ & 0,02 & 0,61 & 0,65 \\
\hline & $-0,15$ & $-0,03$ & 0,24 & 0,28 & $-0,14$ & 0,07 & 0,09 & 0,18 \\
\hline & $-0,1$ & 0,16 & 0,21 & 0,28 & $-0,14$ & 0,06 & $-0,15$ & 0,21 \\
\hline & $-0,09$ & 0,1 & 0,01 & 0,13 & $-0,07$ & $-0,02$ & 0 & 0,07 \\
\hline & $-0,01$ & $-0,1$ & 0,09 & 0,13 & $-0,49$ & $-0,24$ & 0,68 & 0,87 \\
\hline & $-0,06$ & $-0,05$ & 0,24 & 0,25 & $-0,17$ & $-0,37$ & 0,45 & 0,6 \\
\hline & $-0,12$ & 0,08 & 0,31 & 0,34 & $-0,39$ & 0,22 & 0,07 & 0,45 \\
\hline \multirow{10}{*}{$\begin{array}{c}\text { Lucitone } \\
\mathbf{5 5 0}\end{array}$} & $-0,13$ & 0,09 & 0,02 & 0,15 & $-0,09$ & 0,11 & 0,29 & 0,32 \\
\hline & $-0,02$ & 0,23 & 0,16 & 0,28 & $-0,15$ & 0,23 & 0,2 & 0,33 \\
\hline & $-0,05$ & 0,14 & 0,17 & 0,22 & $-0,17$ & 0,06 & 0,48 & 0,51 \\
\hline & $-0,11$ & 0,23 & 0,16 & 0,3 & $-0,47$ & 0,38 & 0,38 & 0,71 \\
\hline & $-0,03$ & $-0,14$ & 0,33 & 0,35 & $-0,26$ & 0,05 & 0,25 & 0,36 \\
\hline & 0,07 & 0,02 & $-0,03$ & 0,07 & $-0,08$ & $-0,05$ & $-0,17$ & 0,19 \\
\hline & $-0,13$ & 0,14 & 0,17 & 0,25 & $-0,48$ & 0,19 & 0,34 & 0,61 \\
\hline & 0,03 & 0,32 & 0,11 & 0,33 & $-0,41$ & 0,5 & 0,14 & 0,66 \\
\hline & $-0,1$ & 0,34 & 0,14 & 0,38 & $-0,09$ & 0,04 & 0,08 & 0,12 \\
\hline & $-0,01$ & 0,06 & 0,36 & 0,36 & $-0,07$ & $-0,16$ & 0,61 & 0,63 \\
\hline
\end{tabular}


Tabela A6- Dados de alteração de cor para Pastilha Corega Tabs.

\begin{tabular}{|c|c|c|c|c|c|c|c|c|}
\hline \multirow{3}{*}{$\begin{array}{c}\text { Resinas } \\
\text { Acrílicas }\end{array}$} & \multicolumn{8}{|c|}{ Tempo (5 minutos) } \\
\hline & \multicolumn{4}{|c|}{ Água } & \multicolumn{4}{|c|}{ Corega Tabs } \\
\hline & $\Delta \mathbf{L}$ & $\Delta \mathbf{a}$ & $\Delta \mathbf{b}$ & $\Delta \mathbf{E}$ & $\Delta \mathbf{L}$ & $\Delta \mathbf{a}$ & $\Delta \mathbf{b}$ & $\Delta \mathbf{E}$ \\
\hline \multirow{10}{*}{$\begin{array}{c}\text { Onda } \\
\text { Cryl }\end{array}$} & $-0,32$ & $-0,17$ & 1,37 & 1,41 & $-0,4$ & $-0,29$ & $-0,08$ & 0,5 \\
\hline & 0,02 & $-0,57$ & 0,55 & 0,79 & $-0,22$ & $-0,09$ & $-0,37$ & 0,43 \\
\hline & $-0,18$ & $-0,06$ & $-0,17$ & 0,25 & $-0,07$ & $-0,22$ & $-0,01$ & 0,23 \\
\hline & $-0,2$ & $-0,33$ & $-0,03$ & 0,38 & $-0,26$ & 0 & $-0,4$ & 0,47 \\
\hline & $-0,05$ & $-0,72$ & 0,4 & 0,82 & $-0,32$ & $-0,03$ & $-0,02$ & 0,32 \\
\hline & $-0,25$ & 0,12 & $-0,32$ & 0,42 & $-0,34$ & 0 & $-0,45$ & 0,56 \\
\hline & $-0,24$ & 0 & $-0,56$ & 0,6 & $-0,25$ & $-0,29$ & 0,28 & 0,47 \\
\hline & $-0,48$ & $-0,13$ & 0,36 & 0,61 & $-0,11$ & $-0,23$ & $-0,05$ & 0,25 \\
\hline & $-0,08$ & $-0,75$ & 0,5 & 0,9 & $-0,35$ & $-0,04$ & 0,1 & 0,36 \\
\hline & $-0,11$ & $-0,08$ & $-0,29$ & 0,32 & $-0,29$ & $-0,04$ & $-0,41$ & 0,5 \\
\hline \multirow{10}{*}{$\begin{array}{c}\text { Lucitone } \\
\mathbf{5 5 0}\end{array}$} & $-0,36$ & $-0,3$ & 0,18 & 0,5 & $-0,15$ & $-0,15$ & $-0,23$ & 0,31 \\
\hline & $-0,23$ & $-0,19$ & $-0,07$ & 0,3 & $-0,18$ & $-0,17$ & $-0,12$ & 0,27 \\
\hline & $-0,13$ & $-0,13$ & $-0,1$ & 0,2 & 0,08 & $-0,4$ & $-0,25$ & 0,47 \\
\hline & $-0,28$ & $-0,13$ & $-0,12$ & 0,33 & $-0,01$ & $-0,35$ & $-0,25$ & 0,43 \\
\hline & $-0,49$ & $-0,27$ & $-0,39$ & 0,68 & $-0,14$ & $-0,31$ & $-0,41$ & 0,53 \\
\hline & $-0,37$ & $-0,21$ & $-0,22$ & 0,47 & $-0,17$ & $-0,18$ & $-0,27$ & 0,36 \\
\hline & $-0,76$ & 0,43 & $-0,16$ & 0,88 & $-0,1$ & $-0,59$ & $-0,32$ & 0,67 \\
\hline & $-0,15$ & $-0,2$ & $-0,28$ & 0,37 & $-0,2$ & $-0,43$ & $-0,04$ & 0,47 \\
\hline & $-0,34$ & $-0,08$ & $-0,55$ & 0,65 & $-0,26$ & $-0,26$ & $-0,26$ & 0,45 \\
\hline & $-0,19$ & $-0,32$ & 0,13 & 0,39 & $-0,32$ & $-0,47$ & $-0,29$ & 0,63 \\
\hline
\end{tabular}


Tabela A7 - Dados de alteração de cor para Hipoclorito de Sódio por 20 minutos.

\begin{tabular}{|c|c|c|c|c|c|c|c|c|c|c|c|c|}
\hline \multirow{3}{*}{$\begin{array}{l}\text { Resinas } \\
\text { Acrílicas }\end{array}$} & \multicolumn{12}{|c|}{ Tempo (20 minutos) } \\
\hline & \multicolumn{4}{|c|}{ Água } & \multicolumn{4}{|c|}{ Hipoclorito de sódio $0,5 \%$} & \multicolumn{4}{|c|}{ Hipoclorito de sódio $1,0 \%$} \\
\hline & $\Delta \mathbf{L}$ & $\Delta \mathbf{a}$ & $\Delta \mathbf{b}$ & $\Delta \mathbf{E}$ & $\Delta \mathbf{L}$ & $\Delta \mathbf{a}$ & $\Delta \mathbf{b}$ & $\Delta \mathbf{E}$ & $\Delta \mathbf{L}$ & $\Delta \mathbf{a}$ & $\Delta \mathbf{b}$ & $\Delta \mathbf{E}$ \\
\hline \multirow{10}{*}{$\begin{array}{l}\text { Onda } \\
\text { Cryl }\end{array}$} & $-0,31$ & $-0,15$ & $-0,04$ & 0,34 & $-0,28$ & $-0,01$ & $-0,03$ & 0,28 & $-0,11$ & $-0,27$ & 0,24 & 0,37 \\
\hline & $-0,1$ & $-0,02$ & 0,08 & 0,12 & $-0,13$ & $-0,19$ & 0,04 & 0,23 & $-0,27$ & $-0,28$ & 0,23 & 0,45 \\
\hline & $-0,37$ & $-0,01$ & $-0,04$ & 0,37 & $-0,14$ & $-0,09$ & $-0,05$ & 0,17 & $-0,02$ & $-0,2$ & $-0,07$ & 0,21 \\
\hline & $-0,3$ & 0,11 & 0,35 & 0,47 & $-0,19$ & $-0,03$ & $-0,21$ & 0,28 & $-0,09$ & $-0,24$ & $-0,15$ & 0,29 \\
\hline & $-0,35$ & 0,08 & 0,05 & 0,36 & $-0,13$ & $-0,4$ & $-0,09$ & 0,43 & $-0,07$ & $-0,2$ & $-0,13$ & 0,24 \\
\hline & $-0,14$ & $-0,03$ & 0,02 & 0,14 & $-0,28$ & $-0,02$ & 0,06 & 0,28 & $-0,02$ & $-0,47$ & $-0,1$ & 0,48 \\
\hline & $-0,22$ & 0,06 & $-0,28$ & 0,36 & $-0,16$ & $-0,21$ & 0 & 0,26 & 0,05 & $-0,29$ & 0,07 & 0,3 \\
\hline & $-0,22$ & 0,05 & $-0,18$ & 0,28 & $-0,01$ & $-0,3$ & $-0,07$ & 0,3 & 0,02 & $-0,39$ & $-0,02$ & 0,39 \\
\hline & $-0,29$ & 0 & 0,17 & 0,33 & $-0,02$ & $-0,27$ & $-0,23$ & 0,35 & $-0,02$ & $-0,36$ & $-0,09$ & 0,37 \\
\hline & $-0,22$ & $-0,14$ & $-0,11$ & 0,28 & $-0,1$ & $-0,27$ & $-0,17$ & 0,33 & $-0,44$ & 0,09 & 0,36 & 0,57 \\
\hline \multirow{10}{*}{$\begin{array}{c}\text { Lucitone } \\
550\end{array}$} & $-0,1$ & $-0,11$ & $-0,09$ & 0,17 & $-0,23$ & $-0,03$ & $-0,23$ & 0,32 & $-0,32$ & $-0,33$ & $-0,3$ & 0,54 \\
\hline & $-0,27$ & $-0,21$ & $-0,05$ & 0,34 & $-0,15$ & $-0,11$ & $-0,18$ & 0,25 & $-0,37$ & $-0,34$ & $-0,22$ & 0,54 \\
\hline & $-0,29$ & $-0,26$ & $-0,13$ & 0,41 & $-0,1$ & $-0,3$ & $-0,01$ & 0,31 & $-0,15$ & $-0,18$ & $-0,14$ & 0,27 \\
\hline & $-0,15$ & $-0,24$ & $-0,11$ & 0,3 & $-0,24$ & $-0,28$ & 0,1 & 0,38 & $-0,27$ & $-0,25$ & $-0,24$ & 0,43 \\
\hline & $-0,15$ & $-0,1$ & $-0,21$ & 0,27 & $-0,15$ & $-0,16$ & $-0,19$ & 0,29 & $-0,44$ & $-0,22$ & $-0,4$ & 0,63 \\
\hline & $-0,1$ & $-0,2$ & 0,01 & 0,22 & 0,01 & $-0,35$ & $-0,09$ & 0,36 & $-0,13$ & $-0,33$ & $-0,31$ & 0,47 \\
\hline & $-0,21$ & $-0,19$ & 0,08 & 0,29 & $-0,35$ & $-0,34$ & $-0,14$ & 0,5 & $-0,45$ & $-0,07$ & 0,08 & 0,46 \\
\hline & $-0,2$ & 0,21 & $-0,26$ & 0,38 & $-0,15$ & $-0,28$ & $-0,23$ & 0,39 & $-0,32$ & $-0,32$ & $-0,25$ & 0,51 \\
\hline & $-0,2$ & $-0,09$ & $-0,1$ & 0,24 & $-0,17$ & $-0,27$ & $-0,15$ & 0,35 & $-0,1$ & $-0,33$ & $-0,23$ & 0,41 \\
\hline & $-0,22$ & $-0,16$ & $-0,12$ & 0,29 & $-0,16$ & $-0,13$ & $-0,46$ & 0,5 & $-0,42$ & $-0,01$ & $-0,24$ & 0,48 \\
\hline
\end{tabular}


Tabela A8- Dados de alteração de cor para Hipoclorito de Sódio por 8 horas.

\begin{tabular}{|c|c|c|c|c|c|c|c|c|c|c|c|c|}
\hline \multirow{3}{*}{$\begin{array}{c}\text { Resinas } \\
\text { Acrílicas }\end{array}$} & \multicolumn{12}{|c|}{ Tempo (8 horas) } \\
\hline & \multicolumn{4}{|c|}{ Água } & \multicolumn{4}{|c|}{ Hipoclorito de sódio 0,5\% } & \multicolumn{4}{|c|}{ Hipoclorito de sódio $1,0 \%$} \\
\hline & $\Delta \mathbf{L}$ & $\Delta \mathbf{a}$ & $\Delta \mathbf{b}$ & $\Delta \mathbf{E}$ & $\Delta \mathbf{L}$ & $\Delta \mathbf{a}$ & $\Delta \mathbf{b}$ & $\Delta \mathbf{E}$ & $\Delta \mathbf{L}$ & $\Delta \mathbf{a}$ & $\Delta \mathbf{b}$ & $\Delta \mathbf{E}$ \\
\hline \multirow{10}{*}{$\begin{array}{c}\text { Onda } \\
\text { Cryl }\end{array}$} & $-0,37$ & $-0,34$ & $-0,74$ & 0,89 & $-0,08$ & $-0,72$ & $-0,42$ & 0,83 & $-0,15$ & $-0,96$ & $-0,39$ & 1,04 \\
\hline & 0,13 & $-0,7$ & $-0,08$ & 0,71 & $-0,1$ & $-0,75$ & $-0,26$ & 0,8 & $-0,11$ & $-0,9$ & $-0,6$ & 1,08 \\
\hline & $-0,52$ & $-0,61$ & $-0,29$ & 0,85 & $-0,31$ & $-0,7$ & $-0,32$ & 0,82 & $-0,3$ & $-0,91$ & $-0,36$ & 1,02 \\
\hline & $-0,27$ & $-0,53$ & $-0,45$ & 0,74 & $-0,17$ & $-0,6$ & $-0,1$ & 0,63 & $-0,19$ & $-0,95$ & $-0,57$ & 1,12 \\
\hline & $-0,22$ & $-0,61$ & $-0,18$ & 0,67 & 0,02 & $-0,74$ & $-0,27$ & 0,78 & $-0,09$ & $-1,09$ & $-0,73$ & 1,31 \\
\hline & $-0,39$ & $-0,78$ & $-0,42$ & 0,96 & 0 & $-0,72$ & $-0,35$ & 0,8 & $-0,11$ & $-0,93$ & $-0,32$ & 0,98 \\
\hline & $-0,69$ & $-0,4$ & $-0,08$ & 0,8 & $-0,24$ & $-0,65$ & $-0,16$ & 0,71 & $-0,23$ & $-0,8$ & $-0,8$ & 1,15 \\
\hline & $-0,2$ & $-0,08$ & $-0,68$ & 0,71 & 0,27 & $-0,76$ & $-0,33$ & 0,87 & $-0,23$ & $-0,73$ & $-0,46$ & 0,89 \\
\hline & $-0,34$ & $-0,31$ & $-0,48$ & 0,66 & $-0,2$ & $-0,54$ & $-0,43$ & 0,71 & $-0,21$ & $-0,62$ & $-0,58$ & 0,87 \\
\hline & $-0,55$ & $-0,46$ & $-0,42$ & 0,83 & 0,17 & $-0,87$ & $-0,21$ & 0,91 & $-0,08$ & $-1,01$ & $-0,62$ & 1,18 \\
\hline \multirow{10}{*}{$\begin{array}{c}\text { Lucitone } \\
550\end{array}$} & 0,02 & $-0,61$ & $-0,18$ & 0,63 & 0,1 & $-0,6$ & $-0,28$ & 0,66 & 0,06 & $-0,72$ & $-0,38$ & 0,81 \\
\hline & 0 & $-0,36$ & $-0,43$ & 0,56 & $-0,07$ & $-0,44$ & $-0,26$ & 0,51 & 0,05 & $-0,69$ & $-0,46$ & 0,83 \\
\hline & $-0,01$ & $-0,62$ & $-0,16$ & 0,64 & 0 & $-0,64$ & $-0,43$ & 0,77 & $-0,12$ & $-0,51$ & $-0,3$ & 0,6 \\
\hline & $-0,03$ & $-0,64$ & $-0,02$ & 0,64 & 0,15 & $-0,57$ & $-0,16$ & 0,61 & $-0,06$ & $-0,65$ & $-0,39$ & 0,76 \\
\hline & $-0,07$ & $-0,47$ & $-0,33$ & 0,57 & 0,1 & $-0,42$ & $-0,23$ & 0,48 & $-0,04$ & $-0,64$ & $-0,37$ & 0,74 \\
\hline & 0,01 & $-0,4$ & $-0,32$ & 0,51 & 0,04 & $-0,51$ & $-0,29$ & 0,58 & 0,04 & $-0,54$ & $-0,36$ & 0,65 \\
\hline & $-0,13$ & $-0,34$ & $-0,48$ & 0,6 & $-0,06$ & $-0,34$ & $-0,35$ & 0,49 & 0,03 & $-0,62$ & $-0,32$ & 0,69 \\
\hline & $-0,05$ & $-0,73$ & 0,26 & 0,77 & $-0,01$ & $-0,48$ & $-0,21$ & 0,52 & $-0,06$ & $-0,74$ & $-0,5$ & 0,89 \\
\hline & $-0,04$ & $-0,6$ & $-0,47$ & 0,76 & 0,06 & $-0,43$ & $-0,21$ & 0,48 & $-0,12$ & $-0,59$ & $-0,29$ & 0,66 \\
\hline & 0,02 & $-0,4$ & $-0,12$ & 0,41 & $-0,06$ & $-0,33$ & $-0,28$ & 0,43 & $-0,02$ & $-0,25$ & $-0,75$ & 0,79 \\
\hline
\end{tabular}


Tabela A9- Resultados de alteração de cor $(\Delta \mathbf{E})$.

\begin{tabular}{|c|c|c|c|c|c|c|c|c|c|c|}
\hline \multirow{3}{*}{$\begin{array}{l}\text { Resinas } \\
\text { Acrílicas }\end{array}$} & \multicolumn{10}{|c|}{ Tempo/dia } \\
\hline & \multicolumn{2}{|c|}{3 minutos } & \multicolumn{2}{|c|}{5 minutos } & \multicolumn{3}{|c|}{20 minutos } & \multicolumn{3}{|c|}{8 horas } \\
\hline & Água & Bony Plus & Água & $\begin{array}{c}\text { Corega } \\
\text { Tabs }\end{array}$ & Água & HS $* 0,5 \%$ & HS* $1 \%$ & Água & HS $* 0,5 \%$ & $H S * 1 \%$ \\
\hline \multirow{10}{*}{$\begin{array}{l}\text { Onda } \\
\text { Cryl }\end{array}$} & 0,27 & 0,94 & 1,41 & 0,5 & 0,34 & 0,28 & 0,37 & 0,89 & 0,83 & 1,04 \\
\hline & 0,28 & 0,08 & 0,79 & 0,43 & 0,12 & 0,23 & 0,45 & 0,71 & 0,8 & 1,08 \\
\hline & 0,12 & 0,23 & 0,25 & 0,23 & 0,37 & 0,17 & 0,21 & 0,85 & 0,82 & 1,02 \\
\hline & 0,15 & 0,65 & 0,38 & 0,47 & 0,47 & 0,28 & 0,29 & 0,74 & 0,63 & 1,12 \\
\hline & 0,28 & 0,18 & 0,82 & 0,32 & 0,36 & 0,43 & 0,24 & 0,67 & 0,78 & 1,31 \\
\hline & 0,28 & 0,21 & 0,42 & 0,56 & 0,14 & 0,28 & 0,48 & 0,96 & 0,8 & 0,98 \\
\hline & 0,13 & 0,07 & 0,6 & 0,47 & 0,36 & 0,26 & 0,3 & 0,8 & 0,71 & 1,15 \\
\hline & 0,13 & 0,87 & 0,61 & 0,25 & 0,28 & 0,3 & 0,39 & 0,71 & 0,87 & 0,89 \\
\hline & 0,25 & 0,60 & 0,9 & 0,36 & 0,33 & 0,35 & 0,37 & 0,66 & 0,71 & 0,87 \\
\hline & 0,34 & 0,45 & 0,32 & 0,5 & 0,28 & 0,33 & 0,57 & 0,83 & 0,91 & 1,18 \\
\hline \multirow{10}{*}{$\begin{array}{c}\text { Lucitone } \\
\quad 550\end{array}$} & 0,15 & 0,32 & 0,5 & 0,31 & 0,17 & 0,32 & 0,54 & 0,63 & 0,66 & 0,81 \\
\hline & 0,28 & 0,33 & 0,3 & 0,27 & 0,34 & 0,25 & 0,54 & 0,56 & 0,51 & 0,83 \\
\hline & 0,22 & 0,51 & 0,2 & 0,47 & 0,41 & 0,31 & 0,27 & 0,64 & 0,77 & 0,6 \\
\hline & 0,30 & 0,71 & 0,33 & 0,43 & 0,3 & 0,38 & 0,43 & 0,64 & 0,61 & 0,76 \\
\hline & 0,35 & 0,36 & 0,68 & 0,53 & 0,27 & 0,29 & 0,63 & 0,57 & 0,48 & 0,74 \\
\hline & 0,07 & 0,19 & 0,47 & 0,36 & 0,22 & 0,36 & 0,47 & 0,51 & 0,58 & 0,65 \\
\hline & 0,25 & 0,61 & 0,88 & 0,67 & 0,29 & 0,5 & 0,46 & 0,6 & 0,49 & 0,69 \\
\hline & 0,33 & 0,66 & 0,37 & 0,47 & 0,38 & 0,39 & 0,51 & 0,77 & 0,52 & 0,89 \\
\hline & 0,38 & 0,12 & 0,65 & 0,45 & 0,24 & 0,35 & 0,41 & 0,76 & 0,48 & 0,66 \\
\hline & 0,36 & 0,63 & 0,39 & 0,63 & 0,29 & 0,5 & 0,48 & 0,41 & 0,43 & 0,79 \\
\hline
\end{tabular}

*Abreviatura: HS = Hipoclorito de sódio. 
Tabela B1- Resultados de alteração de cor, calculados de acordo com a NBS.

\begin{tabular}{|c|c|c|c|c|c|c|c|c|c|c|}
\hline \multirow{3}{*}{$\begin{array}{c}\text { Resinas } \\
\text { Acrílicas }\end{array}$} & \multicolumn{10}{|c|}{ Tempo/dia } \\
\hline & \multicolumn{2}{|c|}{3 minutos } & \multicolumn{2}{|c|}{5 minutos } & \multicolumn{3}{|c|}{20 minutos } & \multicolumn{3}{|c|}{8 horas } \\
\hline & Água & Bony Plus & Água & $\begin{array}{c}\text { Corega } \\
\text { Tabs }\end{array}$ & Água & $\mathrm{HS}^{*} \mathbf{0 , 5} \%$ & $H S * 1 \%$ & Água & HS* 0,5\% & $H S * 1 \%$ \\
\hline \multirow{10}{*}{$\begin{array}{c}\text { Onda } \\
\text { Cryl }\end{array}$} & 0,25 & 0,86 & 1,30 & 0,46 & 0,31 & 0,26 & 0,34 & 0,82 & 0,76 & 0,96 \\
\hline & 0,26 & 0,07 & 0,73 & 0,40 & 0,11 & 0,21 & 0,41 & 0,65 & 0,74 & 0,99 \\
\hline & 0,11 & 0,21 & 0,23 & 0,21 & 0,34 & 0,16 & 0,19 & 0,78 & 0,75 & 0,94 \\
\hline & 0,14 & 0,60 & 0,35 & 0,43 & 0,43 & 0,26 & 0,27 & 0,68 & 0,58 & 1,03 \\
\hline & 0,26 & 0,17 & 0,75 & 0,29 & 0,33 & 0,40 & 0,22 & 0,62 & 0,72 & 1,21 \\
\hline & 0,26 & 0,19 & 0,39 & 0,52 & 0,13 & 0,26 & 0,44 & 0,88 & 0,74 & 0,90 \\
\hline & 0,12 & 0,06 & 0,55 & 0,43 & 0,33 & 0,24 & 0,28 & 0,74 & 0,65 & 1,06 \\
\hline & 0,12 & 0,80 & 0,56 & 0,23 & 0,26 & 0,28 & 0,36 & 0,65 & 0,80 & 0,82 \\
\hline & 0,23 & 0,55 & 0,83 & 0,33 & 0,30 & 0,32 & 0,34 & 0,61 & 0,65 & 0,80 \\
\hline & 0,31 & 0,41 & 0,29 & 0,46 & 0,26 & 0,30 & 0,52 & 0,76 & 0,84 & 1,09 \\
\hline \multirow{10}{*}{$\begin{array}{c}\text { Lucitone } \\
\mathbf{5 5 0}\end{array}$} & 0,14 & 0,29 & 0,46 & 0,29 & 0,16 & 0,29 & 0,50 & 0,58 & 0,61 & 0,75 \\
\hline & 0,26 & 0,30 & 0,28 & 0,25 & 0,31 & 0,23 & 0,50 & 0,52 & 0,47 & 0,76 \\
\hline & 0,20 & 0,47 & 0,18 & 0,43 & 0,38 & 0,29 & 0,25 & 0,59 & 0,71 & 0,55 \\
\hline & 0,28 & 0,65 & 0,30 & 0,40 & 0,28 & 0,35 & 0,40 & 0,59 & 0,56 & 0,70 \\
\hline & 0,32 & 0,33 & 0,63 & 0,49 & 0,25 & 0,27 & 0,58 & 0,52 & 0,44 & 0,68 \\
\hline & 0,06 & 0,17 & 0,43 & 0,33 & 0,20 & 0,33 & 0,43 & 0,47 & 0,53 & 0,60 \\
\hline & 0,23 & 0,56 & 0,81 & 0,62 & 0,27 & 0,46 & 0,42 & 0,55 & 0,45 & 0,63 \\
\hline & 0,30 & 0,61 & 0,34 & 0,43 & 0,35 & 0,36 & 0,47 & 0,71 & 0,48 & 0,82 \\
\hline & 0,35 & 0,11 & 0,60 & 0,41 & 0,22 & 0,32 & 0,38 & 0,70 & 0,44 & 0,61 \\
\hline & 0,33 & 0,58 & 0,36 & 0,58 & 0,27 & 0,46 & 0,44 & 0,38 & 0,40 & 0,73 \\
\hline
\end{tabular}

*Abreviatura: HS = Hipoclorito de sódio. 